Marquette University

e-Publications@Marquette

$1-2014$

\title{
Probing the Human Estrogen Receptor- $\alpha$ Binding Requirements for Phenolic Mono- and Di-Hydroxyl Compounds: A Combined Synthesis, Binding and Docking Study
}

\author{
Christopher McCullough \\ Marquette University \\ Terrence S. Neumann \\ Marquette University, terrence.neumann@marquette.edu \\ Jayapal Reddy Gone \\ Marquette University \\ Zhengjie He \\ Marquette University \\ Christian Herrild \\ Marquette University
}

See next page for additional authors

Follow this and additional works at: https://epublications.marquette.edu/chem_fac

Part of the Medicinal-Pharmaceutical Chemistry Commons, and the Organic Chemistry Commons

\section{Recommended Citation}

McCullough, Christopher; Neumann, Terrence S.; Gone, Jayapal Reddy; He, Zhengjie; Herrild, Christian; Lukesh, Julie; Pandey, Rajesh K.; Donaldson, William A.; and Sem, Daniel S., "Probing the Human Estrogen Receptor- $\alpha$ Binding Requirements for Phenolic Mono- and Di-Hydroxyl Compounds: A Combined Synthesis, Binding and Docking Study" (2014). Chemistry Faculty Research and Publications. 422.

https://epublications.marquette.edu/chem_fac/422 


\section{Authors}

Christopher McCullough, Terrence S. Neumann, Jayapal Reddy Gone, Zhengjie He, Christian Herrild, Julie Lukesh, Rajesh K. Pandey, William A. Donaldson, and Daniel S. Sem

This article is available at e-Publications@Marquette: https://epublications.marquette.edu/chem_fac/422 


\title{
Probing the Human Estrogen Receptor- $\alpha$ Binding Requirements for Phenolic Mono- and Di-Hydroxyl Compounds: A Combined Synthesis, Binding and Docking Study
}

\author{
Christopher McCullough \\ Department of Chemistry, Marquette University \\ Milwaukee, WI \\ Department of Cancer Systems Imaging \\ University of Texas-M.D. Anderson Cancer Center \\ Houston, $T X$ \\ Terrence S. Neumann \\ Department of Chemistry, Marquette University \\ Milwaukee, WI \\ School of Pharmacy, Center for Structure-based Drug Design and \\ Development, Concordia University Wisconsin \\ Mequon, WI \\ Jayapal Reddy Gone \\ Department of Chemistry, Marquette University \\ Milwaukee, WI \\ Toronto Research Chemicals Inc. \\ North York, Toronto M3J 2J8, Canada
}

Bioorganic \& Medicinal Chemistry, Vol. 22, No. 1 (January 1, 2014): pg. 303-310. DOI. This article is (c) Elsevier and permission has been granted for this version to appear in e-Publications@Marquette. Elsevier does not grant permission for this article to be further copied/distributed or hosted elsewhere without the express permission from Elsevier. 
NOT THE PUBLISHED VERSION; this is the author's final, peer-reviewed manuscript. The published version may be accessed by following the link in the citation at the bottom of the page.

\section{Zhengjie He}

Department of Chemistry, Marquette University

Milwaukee, WI

The State Key Laboratory of Elemento-Organic Chemistry and

Department of Chemistry, Nankai University

Tianjin, China

Christian Herrild

Department of Chemistry, Marquette University

Milwaukee, WI

Julie Wondergem, (nee Lukesh)

Department of Chemistry, Marquette University

Milwaukee, WI

Division of Natural \& Applied Sciences

University of Wisconsin-Green Bay

Green Bay, WI

Rajesh K. Pandey

Department of Chemistry, Marquette University

Milwaukee, WI

AllExcel Inc.

West Haven, CT

William A. Donaldson

Department of Chemistry, Marquette University

Milwaukee, WI

Daniel S. Sem

Department of Chemistry, Marquette University

Milwaukee, WI

School of Pharmacy, Center for Structure-based Drug Design and

Development

Concordia University Wisconsin,

Mequon, WI

Abstract: Various estrogen analogs were synthesized and tested for binding to human ERa using a fluorescence polarization displacement assay. Binding affinity and orientation were also predicted using docking calculations.

Bioorganic \& Medicinal Chemistry, Vol. 22, No. 1 (January 1, 2014): pg. 303-310. DOI. This article is C Elsevier and permission has been granted for this version to appear in e-Publications@Marquette. Elsevier does not grant permission for this article to be further copied/distributed or hosted elsewhere without the express permission from Elsevier. 
Docking was able to accurately predict relative binding affinity and orientation for estradiol, but only if a tightly bound water molecule bridging Arg394/Glu353 is present. Di-hydroxyl compounds sometimes bind in two orientations, which are flipped in terms of relative positioning of their hydroxyl groups. Di-hydroxyl compounds were predicted to bind with their aliphatic hydroxyl group interacting with His524 in ERa. One nonsteroid-based dihdroxyl compound was 1000-fold specific for ER $\beta$ over ERa, and was also 25 -fold specific for agonist ER $\beta$ versus antagonist activity. Docking predictions suggest this specificity may be due to interaction of the aliphatic hydroxyl with His475 in the agonist form of ER $\beta$, versus with Thr299 in the antagonist form. But, the presence of this aliphatic hydroxyl is not required in all compounds, since mono-hydroxyl (phenolic) compounds bind ERa with high affinity, via hydroxyl hydrogen bonding interactions with the ERa Arg394/Glu353/water triad, and van der Waals interactions with the rest of the molecule.

Keywords: Estrogen receptor, Docking, Phenolic, Breast cancer, Endocrine disruptor

\section{Introduction}

Estrogen receptor-a ( $\mathrm{ERa}$ ) is a 595-residue, $66 \mathrm{kDa}$ protein with a ligand binding domain of 245 residues ( $28 \mathrm{kDa}$ ). ERa, along with estrogen receptor- $\beta(E R \beta)$, belongs to the nuclear hormone family of intracellular receptors. It is one of the two principal receptors responsible for binding the endogenous estrogen, 17 $\beta$-estradiol (E2), shown in Figure $1 .{ }^{1}$ In the nucleus, ER binds to DNA as a dimer, recruiting coactivators or corepressors that will result in activating or repressing the transcription of different genes. ${ }^{3}$ Binding of E2 activates the $E R$, regulating activity. Both ERa and ER $\beta$ forms are found in different tissue types. However, ERa is expressed more in breast tissue and is also known to be involved in the pathway that regulates breast cancer development. 2,4 ERa antagonists such as raloxifene (Fig. 1) can bind to ER in the same ligand-binding domain as E2, and disrupt normal ER cellular function. ${ }^{4,5}$

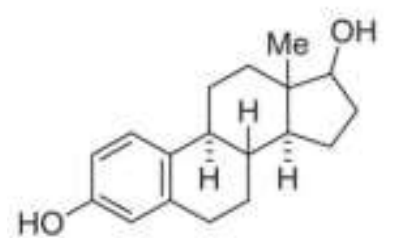

E2

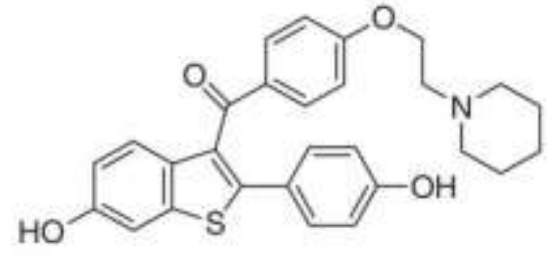

raloxifene

Figure 1 Structures of $17 \beta$-estradiol and raloxifene.

Bioorganic \& Medicinal Chemistry, Vol. 22, No. 1 (January 1, 2014): pg. 303-310. DOI. This article is @ Elsevier and permission has been granted for this version to appear in e-Publications@Marquette. Elsevier does not grant permission for this article to be further copied/distributed or hosted elsewhere without the express permission from Elsevier. 
A key structural feature of E2 is the presence of two hydroxyl groups that are separated by $11 \AA$, which permits interaction with conserved binding site residues Arg394/Glu353 and His 524. But, the receptor is capable of binding many other compounds whose structures resemble that of the E2 hormone. ${ }^{6}$ Some of these compounds are endogeneous, such as estrone and other human estrogens; and, some are exogeneous, like the drugs raloxifene (Fig. 1) or tamoxifen that are used to treat breast cancer and osteoporosis. ${ }^{7}$ In addition to drugs, there exist other exogeneous compounds, some naturally occurring like phytoestrogens and some synthetic such as organochlorines, that have measurable estrogenic activity. ${ }^{5}$ Many of these latter compounds have been shown to be linked to breast cancer as well as birth defects. ${ }^{8,9}$ Through the National Institutes of Environmental Health Sciences, the BSB (Biomolecular Screening Branch), and other federal agencies, the government has developed a program to test many of the chemicals currently in our environment, to see if they have estrogenic activity. ${ }^{10}$

Because of the estrogen receptor's prominent role as a breast cancer drug target, along with the threat posed by the potentially large number of estrogen agonists and antagonists in our environment (e.g., endocrine disruptors), it is essential to gain a better understanding of the binding requirements of the ERa ligand pocket. This understanding will allow for the design of better breast cancer drugs that interfere with the carcinogenic activity of estrogen agonists, and improve our ability to predict which pollutants might bind to ERa. Such predictions are strengthened by a better definition of the molecular features that trigger agonist or antagonist effects, as well as a validation of the docking methods used to predict binding.

One technique that can provide a quick and reliable experimental measurement of binding affinity is fluorescence polarization. ${ }^{11} \mathrm{~A}$ fluorescence polarization displacement assay can be used to screen non-fluorescent molecules, by displacing a fluorescent probe with the molecule of interest. ${ }^{12}$ Such fluorescence polarization displacement assays have been developed previously for ERa and ER $\beta$, based on a fluorescein isothiocyanate (FITC)-tagged estradiol (FE2). ${ }^{13,14}$ One such assay is available from Invitrogen. ${ }^{15}$ Subsequent studies in our lab improved the synthesis of F-E2 and examined the in vivo behavior of F-E2 in vivo, in fish. F-E2 was found to localize in cells

Bioorganic \& Medicinal Chemistry, Vol. 22, No. 1 (January 1, 2014): pg. 303-310. DOI. This article is (C) Elsevier and permission has been granted for this version to appear in e-Publications@Marquette. Elsevier does not grant permission for this article to be further copied/distributed or hosted elsewhere without the express permission from Elsevier. 
that develop into reproductive organs, consistent with the proposed role of E2 in gender determination in fish. ${ }^{16}$ An analogous fluorescence polarization method was developed using an intrinsically fluorescent nonsteroid estrogen. ${ }^{17}$

Herein we present the synthesis of a series of phenolic monoand di-hydroxyl estrogen analogs, which were tested for binding affinity for human ERa, using a fluorescence polarization displacement assay based on F-E2. Estrogen (E2) is a phenolic compound comprised of a steroid core and a second hydroxyl group that is $11 \AA$ from the phenolic hydroxyl. Compounds synthesized herein have the phenolic core, but vary in terms of whether they: (a) are steroid-based, and (b) possess a second hydroxyl group, $\sim 11 \AA$ from the phenol. In addition to binding affinity measurements for compounds, docking calculations were performed. Docking is the process of positioning a ligand into the binding site of a protein and calculating a binding energy for each pose. ${ }^{18}$ It has become an important early-stage method for finding molecules likely to bind to a protein, allowing for many chemicals to be rapidly screened as potential drug leads. ${ }^{18-20}$ Docking has also proven useful for identifying compounds as targets for pollutant remediation. ${ }^{21}$ Besides predicting relative binding affinity, docking is used to predict the orientation or pose of a known ligand bound to a protein. ${ }^{22}$ Comparison of docking predictions with experimental affinity measurements allows one to rationalize binding site requirements, and also provides validation of the predictive ability of the docking calculations for a given target (e.g., ERa) and class of compounds (phenolic mono- and di-hydroxyl compounds). This is important because such experimental validation provides greater confidence in the docking calculations when they are done on larger sets of compounds, where experimental verification might not be feasible.

\section{Results and discussion}

\subsection{Synthesis}

Wittig olefination of estrone benzyl ether, ${ }^{23}$ followed by epoxidation with mCPBA gave the known ${ }^{24}$ epoxide $\mathbf{1}$ as a mixture of diastereomers (Scheme 1). Deprotonation of $\mathbf{1}$ with lithium diisopropylamine, followed by cleavage of the benzyl ether under

Bioorganic \& Medicinal Chemistry, Vol. 22, No. 1 (January 1, 2014): pg. 303-310. DOI. This article is @ Elsevier and permission has been granted for this version to appear in e-Publications@Marquette. Elsevier does not grant permission for this article to be further copied/distributed or hosted elsewhere without the express permission from Elsevier. 
dissolving metal conditions gave the allylic alcohol 2. Palladium catalyzed alkoxycarbonylation of the vinyl triflate derived from estrone benzyl ether, according to the literature procedure, ${ }^{25}$ gave $n$-propyl (20S)-3-(phenylmethoxy)-estra-1,3,5(10),16-tetraene- 17-carboxylate (3), which upon reduction in the presence of Raney-Ni gave the saturated ester 4. The skipped diene (20S)-3- (phenylmethoxy)19,24-dinorchola-1,3,5(10),16,22-pentaene (5) was prepared by the literature procedure. ${ }^{25}$ Hydrogenation of the less substituted olefin in the presence of Wilkinson's catalyst, followed by debenzylation gave $\mathbf{7}$. Hydroboration-oxidation of $\mathbf{5}$, by the literature procedure ${ }^{26}$ gave (20S)-3-(phenylmethoxy)-19,24- dinorchola-1,3,5(10),16-tetraen-23ol (8). Subjecting $\mathbf{8}$ to acid resulted in the spirocyclic tetrahydrofuran 9 in quantitative yield, which upon catalytic hydrogenolysis gave $\mathbf{1 0}$. Alternatively, debenzylation of $\mathbf{8}$ afforded $\mathbf{1 1}$. Oxidation of $\mathbf{1 1}$ gave the aldehyde 12. Reaction of $\mathbf{1 2}$ with an excess of methyl Grignard, followed by work-up with saturated aqueous ammonium chloride proceeded by cyclization to afford the spirocyclic tetrahydrofuran $\mathbf{1 3}$ as a mixture of diastereomers.

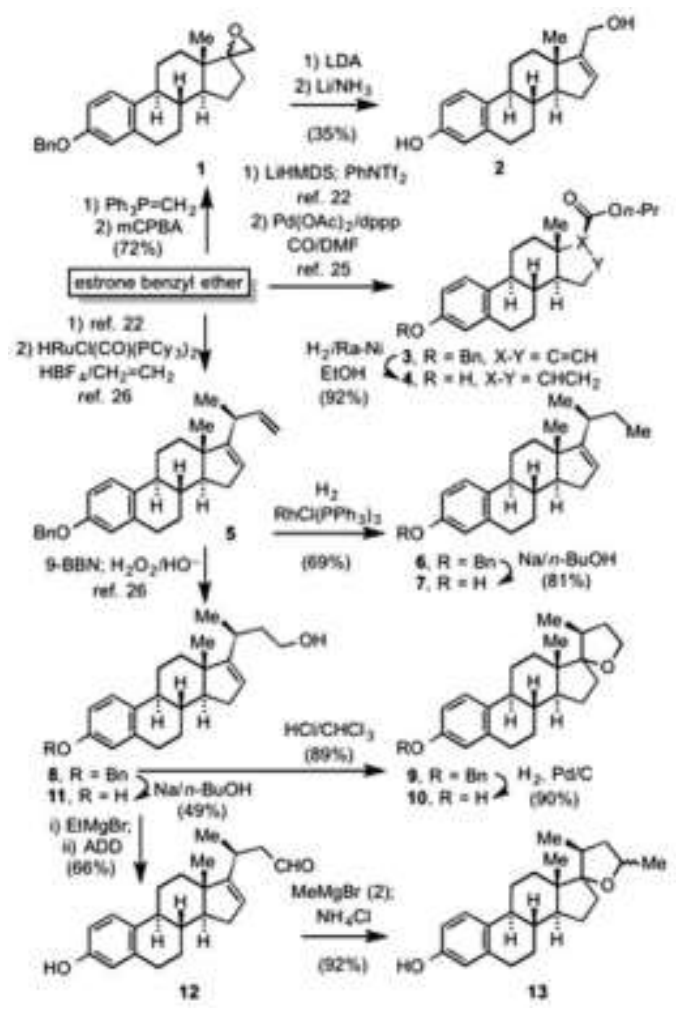

Scheme 1 Preparation of tetra- and pentacyclic ER analogs (ADD $=1,1^{\prime}$ (azodicarbonyl)dipiperidine). 
NOT THE PUBLISHED VERSION; this is the author's final, peer-reviewed manuscript. The published version may be accessed by following the link in the citation at the bottom of the page.

A series of $p$-substituted phenols were also prepared (Scheme $2)$. Reduction of 4-(4'-hydroxyphenyl)cyclohexanone gave a separable mixture of trans-4-(4'-hydroxy-cyclohexyl)phenol 15 (86\%) and its cis- diastereomer 14 (10\%). The stereochemical assignments for each were made by comparison to their literature spectral data. ${ }^{27}$ Reaction of 4-(4'-hydroxyphenyl)cyclohexanone with hydroxylaminehydrochloride gave the oxime 16. [4-((4'-Hydroxyphenyl) cyclohepta2,6-dienyl)methanol $\mathbf{1 7}$ was prepared from $p$-acetoxystyrene according to the literature procedure. ${ }^{28}$ This involved cross metathesis with (1-methoxycarbonyl-2-vinyl-3-pentene- 1,5-diyl) $\mathrm{Fe}(\mathrm{CO})_{3}$ (21), followed by oxidatively induced reductive elimination. Reduction of the resultant cyclopropane-carboxylate and concomitant Cope [3,3]rearrangement gave the cycloheptadiene 17. Catalytic reduction of $\mathbf{1 7}$ gave the saturated cycloheptane 18. Finally, Heck-type coupling of methyl 5-bromo- 2-furanoate with $p$-acetoxystyrene gave the transstyrylfuranoate 19, which upon reduction with lithium aluminum hydride gave the furfuryl alcohol 20.

Bioorganic \& Medicinal Chemistry, Vol. 22, No. 1 (January 1, 2014): pg. 303-310. DOI. This article is @ Elsevier and permission has been granted for this version to appear in e-Publications@Marquette. Elsevier does not grant permission for this article to be further copied/distributed or hosted elsewhere without the express permission from Elsevier. 


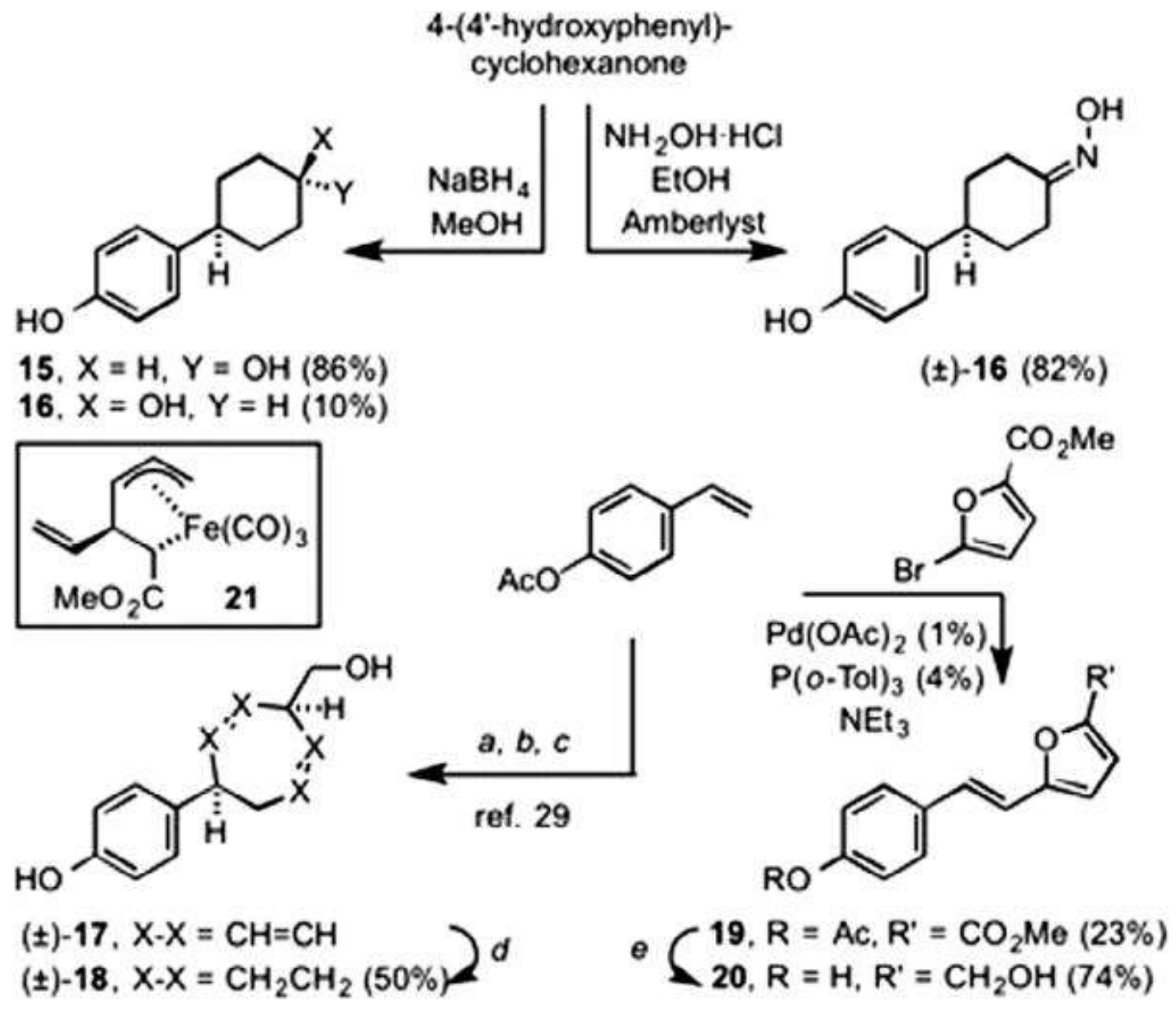

Scheme 2 Preparation pf $p$-substituted phenols. Reagents and conditions: (a) 21,Grubbs 1st generation catalyst; (b) $\mathrm{H}_{2} \mathrm{O}_{2} / \mathrm{NaOH}$; (c) $\mathrm{LiAIH}_{4}$, then $160{ }^{\circ} \mathrm{C}$; (d) $\mathrm{H}_{2}$, $20 \% \mathrm{Pd} / \mathrm{C}, \mathrm{MeOH}$; (e) $\mathrm{LiAIH}_{4}, \mathrm{Et}_{2} \mathrm{O}$. (See above-mentioned reference for further information.)

\subsection{Fluorescence polarization displacement and cell- based ERa and ER $\beta$ luminescence activity assays}

Twelve compounds from Schemes 1 and and 2 were screened using fluorescence polarization, for their ability to bind ERa (Table 1). Only six compounds showed any significant affinity for the receptor at concentrations as high as $1 \mu \mathrm{M}$. These compounds include five of the six steroid-core compounds-2, 4, 7, 11, and 13-and one bicyclic compound-18. Of the remaining six compounds which did not bind to $\mathrm{ERa}$, one has the steroid core while the others contain the linked ring cores containing a flanking hydroxyl group-a structure whose hydrophobic interior and hydrophilic exterior resembles that of 
estrogen itself. The highest affinity ERa ligand was 2, with a $K_{\mathrm{d}}$ (32 $\mathrm{nM})$ approaching that of E2 ( $3 \mathrm{nM}) . \mathbf{1 8}$ is the only non-steroid core compound with measurable ERa binding affinity, but an accurate $K_{d}$ could not be obtained (estimated to be $>1 \mu \mathrm{M}$ ).

Table 1 Dissociation constants $\left(K_{d}\right)$ from the fluorescence polarization displacement assay and $\mathrm{IC}_{50}$ data from cell-based ERa and ER $\beta$ agonist assays and ER $\beta$ antagonist assays

$\begin{array}{lllll}\text { Compound } & \begin{array}{l}\text { ERa Kd } \\ (\mathbf{n M})\end{array} & \begin{array}{l}\text { ERa agonist } \\ \text { IC50 }(\mathbf{n M})\end{array} & \begin{array}{l}\text { ERß agonist } \\ \text { IC } \mathbf{5 0}(\mathbf{n M})\end{array} & \begin{array}{l}\text { ERß } \\ \text { antagonist } \\ \text { IC50 (nM) }\end{array} \\ \mathbf{E 2} & 3^{15} & 1.3^{27} & 46 \mathrm{pM}^{27} & \mathrm{NA} \\ \mathbf{1 1} & 320 \pm 40 & \mathrm{NA} & 108 \pm 67 & 275 \pm 40 \\ \mathbf{4} & 320 \pm 40 & 92 \pm 1 & 9.8 \pm 2 & \mathrm{NA} \\ \mathbf{7} & 160 \pm 10 & \mathrm{NA} & 88 \pm 9 & 70 \pm 15 \\ \mathbf{1 3} & 160 \pm 10 & 484 \pm 1 & 111 \pm 26 & \mathrm{NA} \\ \mathbf{2} & 32 \pm 5 & 145 \pm 1 & 6.8 \pm 0.2 & \mathrm{NA} \\ \mathbf{1 8} & >1 \mu \mathrm{M} & \mathrm{NA} & 5.4 \pm 0.3 & 137 \pm 100\end{array}$

ERa antagonist behavior was not observed. NA indicates data was not of sufficient quality to measure activity. Assay data for E2 binding to ERa, ${ }^{15}$ and ERa agonist and $E R \beta$ agonist and antagonist activity in cellular assays,${ }^{27}$ were previously reported.

Cell-based ERa and ER $\beta$ luminescence assays were performed to determine whether the ERa ligands were acting as agonists or antagonists, and whether they had specificity for the a isoform (Table 1, Fig. S1-6). Three compounds, 4, 13, and 2, showed agonist activity in the ERa assay; and, all six compounds showed ER $\beta$ agonist activity, with 4, 2, and 18 being the most potent; 18 is unique in its selectivity for ER $\beta$ over ERa, and is 25 -fold more potent as an agonist, versus antagonist. 11, 7, and $\mathbf{1 8}$ displayed ER $\beta$ antagonist activity, with $\mathbf{7}$ being the most potent.

\subsection{Docking}

Compounds were computationally docked into human ERa and $E R \beta$ in agonist and antagonist conformations. Poses for ERa are shown in Fig. S7-8. Initial control docking studies were performed with E2, to validate the docking method by demonstrating an ability to reproduce the known binding mode from the crystal structure. Interestingly, E2

Bioorganic \& Medicinal Chemistry, Vol. 22, No. 1 (January 1, 2014): pg. 303-310. DOI. This article is (C) Elsevier and permission has been granted for this version to appear in e-Publications@Marquette. Elsevier does not grant permission for this article to be further copied/distributed or hosted elsewhere without the express permission from Elsevier. 
docked with similar predicted affinity in two distinct poses for the ERa agonist conformation (Fig. S9, Table S1), essentially flipping the positioning of the two hydroxyl groups with regard to interactions with Arg394/Glu353 and His524, located on opposite sides of the pocket. The predicted pose with the phenolic hydroxyl near Arg394/Glu353 is referred to as the 'normal' mode, and that with the phenolic hydroxyl near His524 as the 'reversed' mode. But, if docking is performed on receptor that has the tightly bound water present near Arg394/Glu353, then only the expected pose is obtained; and, E2 is the ligand with highest predicted affinity (Table 2), as expected. Thus, all docking was performed with the Arg394/Glu353 water present. This binding mode has been studied previously using molecular dynamics, and illustrates the important role of active site water molecules in ligand binding. ${ }^{30}$

Table 2 Docking of compounds prepared in Schemes 1 and and22 into the agonist and antagonist conformations of ERa and ERB

\begin{tabular}{|c|c|c|c|c|}
\hline $\begin{array}{r}\text { Compound D } \\
\text { S } \\
\text { E }\end{array}$ & $\begin{array}{l}\text { Docking } \\
\text { score for } \\
\text { ERa agonist } \\
\left(\mathrm{kcal} \mathrm{mol}^{-1}\right)\end{array}$ & $\begin{array}{l}\text { Docking score } \\
\text { for ERa } \\
\text { antagonist } \\
\left(\mathrm{kcal} \mathrm{mol}^{-1}\right)\end{array}$ & $\begin{array}{l}\text { Docking } \\
\text { score for } \\
\text { ERß agonist } \\
\left(\mathrm{kcal} \mathrm{mol}^{-1}\right)\end{array}$ & $\begin{array}{l}\text { Docking score } \\
\text { for ER } \\
\text { antagonist } \\
\left(\mathrm{kcal} \mathrm{mol}^{-1}\right)\end{array}$ \\
\hline E2 & -10.36 & -9.70 & -10.11 & -9.29 \\
\hline 4 & -10.29 & -10.38 & -10.66 & -10.13 \\
\hline 2 & -9.82 & -9.86 & -10.40 & -9.71 \\
\hline 11 & -9.80 & -9.30 & -10.18 & -10.28 \\
\hline 7 & -9.74 & -9.37 & -10.00 & -10.36 \\
\hline 10 & -8.82 & -9.21 & -6.41 & -10.08 \\
\hline 13 & -8.73 & -8.82 & -4.82 & -9.92 \\
\hline 18 & -8.22 & -7.66 & -7.86 & -7.48 \\
\hline 17 & -7.37 & -7.10 & -6.97 & -6.83 \\
\hline 16 & -7.27 & -6.99 & -6.92 & -6.96 \\
\hline 20 & -6.93 & -7.20 & -7.34 & -7.11 \\
\hline 15 & -6.85 & -6.38 & -6.56 & -6.77 \\
\hline 14 & -6.41 & -6.28 & -6.43 & -6.60 \\
\hline
\end{tabular}

Compounds identified as having ERa affinity in the fluorescence polarization displacement assay are in bold.

Docking results were rank ordered according to the lowest energy pose for binding to the ERa agonist conformation, from the cluster with the highest population (Table 2). Identifying the

Bioorganic \& Medicinal Chemistry, Vol. 22, No. 1 (January 1, 2014): pg. 303-310. DOI. This article is C Elsevier and permission has been granted for this version to appear in e-Publications@Marquette. Elsevier does not grant permission for this article to be further copied/distributed or hosted elsewhere without the express permission from Elsevier. 
compounds with measurable $K_{d}$ values from the fluorescence polarization displacement assay (shown as bold in Table 2) indicates that the docking procedure using Autodock4 was able to separate the binding ligands from the non-binding ligands. ER is a unique docking target, since the binding site is comprised of a nearly closed hydrophobic pocket, flanked by hydrogen bonding groups that could provide specificity. ${ }^{31}$ Care in analyzing docking results is needed due to the large binding area in which ligands can potentially bind, and symmetry of the pocket. Three examples of reversed binding modes that are likely false are shown in Figure 2.
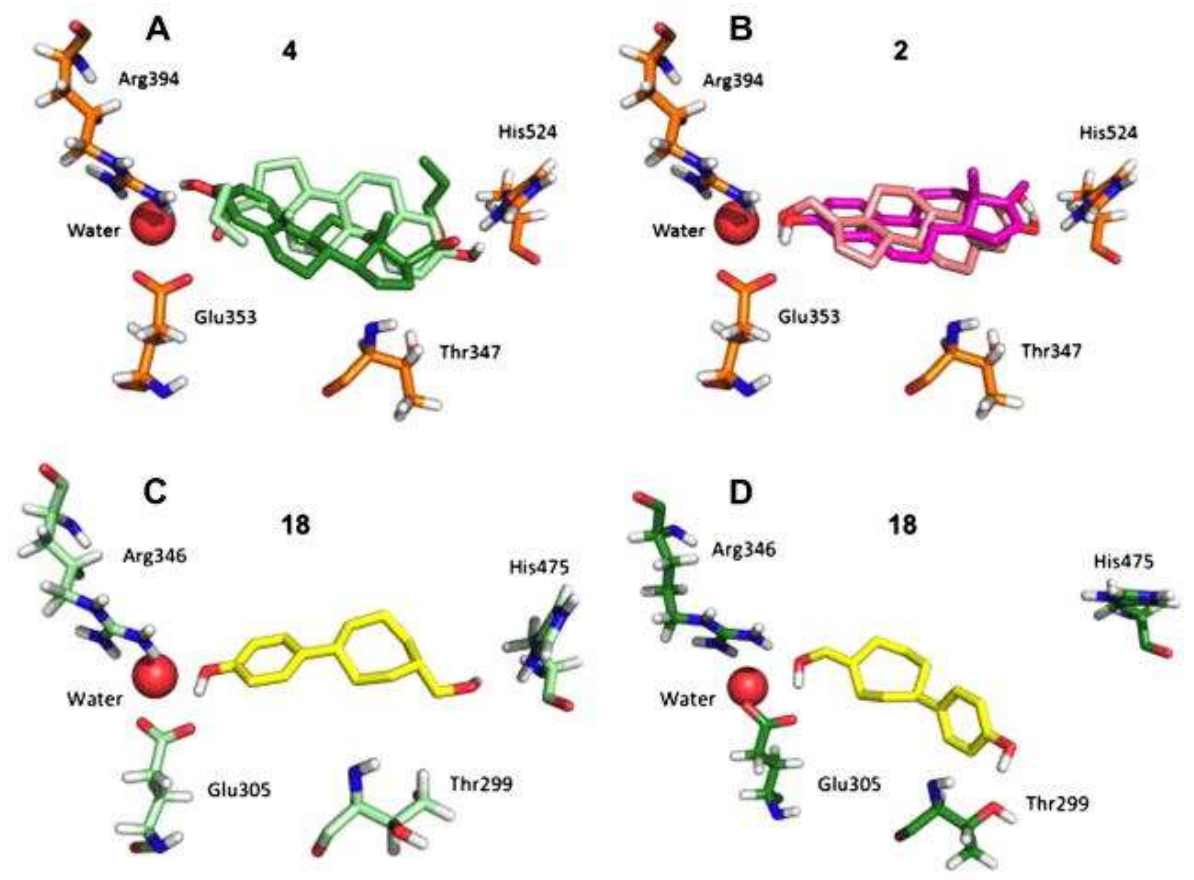

Figure 2 Lowest energy docking poses from clusters where ligands were predicted to bind in two modes $(A-B)$. The human ERa estrogen receptor that was used was in the agonist conformation (PDB code 1ere; chain $A$ ). Panel $C$ shows the predicted binding orientation for $\mathbf{1 8}$ in ERB, agonist conformation (PDB code 2jj3; chain A). Panel $D$ shows the predicted binding orientation for 18 in $E R \beta$, antagonist conformation (PDB code $1 / 2 \mathrm{j}$; chain A).

Interestingly, while estradiol docked in only one orientation when the bound water is present, other compounds were still predicted to bind in two orientations (Table 2; Fig. 2), one normal (with the phenolic hydroxyl interacting with Arg394/Glu353/Water), and one 'reversed,' where the phenolic hydroxyl interacts with His524. This promiscuity in predicted binding mode may be due to symmetry in di- 
hydroxyl molecules like 2 (Fig. 2). Curiously, the mono-hydroxyl 4 also is predicted to bind in a reversed mode (Fig. 2), but with much lower affinity relative to the normal mode. This is likely due to the fact that $\mathbf{4}$ has only one hydroxyl group, the phenol, which provides significant binding energy via interaction with the Arg394/Glu353/water triad. It is also clear that the aliphatic hydroxyl interaction with His524 is not essential, since it is absent in $\mathbf{4}$ and $\mathbf{7}$, and yet both bind with reasonable affinity $\left(\mathrm{IC}_{50}=160-320 \mathrm{nM}\right)$. Indeed, this observation is consistent with the ability of phenolic endocrine disruptors, which contain only one hydroxyl group, to bind to ER. ${ }^{32}$

The docking of compounds $\mathbf{1 0}$ and $\mathbf{1 3}$ in the ER $\beta$-agonist conformation displayed predicted binding energies that were weaker than expected in Table 2. Inspection of the binding site (Fig. S10) showed that these ligands experience steric clashes with binding site sidechains. Additionally, for structures $\mathbf{1 0}$ and 13, the oxygen atom in the tetrahydrofuran ring was not positioned near His 475 for $\mathbf{1 0}$ or (for reversed mode binding) near Arg346, Glu305 for 13, to allow for hydrogen bond formation.

Compound $\mathbf{1 8}$ is in a unique class, in that it is not based on the steroid core, is selective for the $\beta$ over the a ER isoform, and is 25fold selective for ER $\beta$ agonist versus ER $\beta$ antagonist activity (Table 1 ). Docking pose predictions (Fig. $2 \mathrm{C}$ and $\mathrm{D}$ ) show that $\mathbf{1 8}$ could form two hydrogen bonds (one with His475) in the ER $\beta$ agonist conformation, whereas in the ER $\beta$ antagonist conformation, hydrogen bonding is with Thr299, rather than His475. A molecular overlay of E2 and 18 (Fig. S11) shows the oxygen atoms of the two molecules are well-aligned.

\section{Conclusions}

Human ERa remains an important target for therapeutic interventions (cancer; osteoporosis). Estrogen has a key interaction between its phenolic hydroxyl and a binding site Arg394/Glu353/water triad, along with other important interactions including van der Waals interactions with the steroid core, and hydrogen bonding interactions between an aliphatic hydroxyl group and His524 (His475 in ERß). The two estradiol hydroxyls are located $11 \AA$ from each other. The studies presented herein probe the importance of interactions with the

Bioorganic \& Medicinal Chemistry, Vol. 22, No. 1 (January 1, 2014): pg. 303-310. DOI. This article is C Elsevier and permission has been granted for this version to appear in e-Publications@Marquette. Elsevier does not grant permission for this article to be further copied/distributed or hosted elsewhere without the express permission from Elsevier. 
aliphatic hydroxyl and with the steroid core, using a series of novel mono- and di-hydroxyl compounds (Schemes 1 and and22).

The estrogen analog with highest measured affinity in the fluorescence polarization displacement assay $\left(\mathrm{IC}_{50}=32 \mathrm{nM}\right)$ and second highest predicted affinity is the di-hydroxyl steroid $\mathbf{2}$, which has a single point of unsaturation in the D-ring, and (relative to estradiol) has its aliphatic hydroxyl extended by one methylene group. Nonetheless, this gives an $\mathrm{O}-\mathrm{O}$ distance essentially equivalent to that for estradiol. Di-hydroxyl steroid $\mathbf{2}$ behaves as an ERa agonist, and has no selectivity for a versus $\beta$ ER isoforms. Indeed, $\mathbf{2}$ is a potent ER $\beta$ agonist and antagonist. In contrast, $\mathbf{1 8}$ binds weakly to ERa, yet has on $\mathrm{O}-\mathrm{O}$ distance $(11.1 \AA$ ) that is similar to $\mathbf{2}$. Of particular interest is the fact that $\mathbf{1 8}$ has the expected interaction with His475 in the ER $\beta$ agonist docking, whereas in the ER $\beta$ antagonist docking this aliphatic hydroxyl group is predicted to interact instead with Thr299 (Fig. 2). This could explain why $\mathbf{1 8}$ is so selective (25-fold) as an ER $\beta$ agonist, versus as an antagonist (Table 1 ). Most of the other compounds from Scheme 2 that lacked the steroid core did not bind to ERa, even though they possessed the phenolic hydroxyl. Compounds $(\mathbf{4}, \mathbf{1 3}, \mathbf{2})$, which possessed ERa agonist activities, were also ER $\beta$ agonists; but, not ER $\beta$ antagonists. And, these compounds were more selective for ER $\beta$ over ERa.

In summary, several compounds have been identified that are potent ERa agonists, and also behave as ER $\beta$ agonists and antagonists (Table 1). The most potent is the dihydroxyl steroid $\mathbf{2}$. Also, the nonsteroid dihydroxyl compound $\mathbf{1 8}$ is 1000-fold more selective for ER $\beta$ over ERa, and appears to adopt a different binding mode in these two targets (Fig. 2).

\section{Experimental}

\subsection{General methods}

The $\beta$-estradiol $(\min 98 \%$ ) and fluorescein (FITC) were purchased from Sigma. The a-ER and a-ER screening buffer were from Invitrogen. The FITC-estradiol linked tracer used in the experiments was synthesized by as described previously. (1) DMSO- $d_{6}$ was

Bioorganic \& Medicinal Chemistry, Vol. 22, No. 1 (January 1, 2014): pg. 303-310. DOI. This article is (c) Elsevier and permission has been granted for this version to appear in e-Publications@Marquette. Elsevier does not grant permission for this article to be further copied/distributed or hosted elsewhere without the express permission from Elsevier. 
purchased from Cambridge Isotopes. The 96-well plates used were black, polystyrene, NBS (non-binding surface), flat-bottom plates obtained from Corning. A PolarStar Galaxy fluorescent plate reader was used and controlled with FLUOStar Galaxy software (version 4.300 ). Estrone benzyl ether ${ }^{23}$ and compounds $\mathbf{3}^{25} \mathbf{5}^{26} \mathbf{8}^{26}$ and $\mathbf{1 7}^{28}$ were prepared by the literature procedures.

\subsection{Estrogen analog synthesis}

\subsubsection{3-Hydroxyestra-1,3,5(10),16-tetraene-17-methanol (2)}

To a solution of methyl triphenylphosphonium bromide (589 mg, $1.65 \mathrm{mmol})$ in THF $(10 \mathrm{~mL})$ at $-40^{\circ} \mathrm{C}$ under $\mathrm{N}_{2}$, was added a solution of $n$-butyl lithium $(0.66 \mathrm{~mL}, 2.5 \mathrm{M}$ in hexanes, $1.7 \mathrm{mmol})$. The ylide solution was warmed to room temperature and a solution of estrone benzyl ether $(200 \mathrm{mg}, 0.556 \mathrm{mmol})$ in THF $(7 \mathrm{~mL})$ was added. The mixture was stirred for $12 \mathrm{~h}$, and then heated at reflux for $5 \mathrm{~h}$. The solution was cooled, and concentrated, and the residue was purified by column chromatography $\left(\mathrm{SiO}_{2}\right.$, hexanes-ethyl acetate $\left.=4: 1\right)$ to afford the exocyclic methylene product (168 mg, $84 \%$ ) as a colorless solid. This product was used in the next step without further characterization. To a solution of the olefin $(100 \mathrm{mg}, 0.279 \mathrm{mmol})$ in dichloromethane $(6 \mathrm{~mL})$ at $0{ }^{\circ} \mathrm{C}$, was added solid $\mathrm{m}$ chloroperoxybenzoic acid $(57.5 \mathrm{mg}, 0.333 \mathrm{mmol})$. The reaction mixture was $4 \mathrm{~h}$, and then quenched with aqueous $\mathrm{NaHCO}_{3}$. The mixture was extracted several times with dichloromethane, dried and concentrated to afford the epoxide $\mathbf{1}(90 \mathrm{mg}, 86 \%$ ) as a colorless oil, which was used in the next step without further purification. To a solution of the epoxide $(50 \mathrm{mg}, 0.13 \mathrm{mmol})$ in hexanes $(1 \mathrm{~mL})$ and toluene $(0.5 \mathrm{~mL})$ was added HMPA (1 drop). The mixture was cooled to $-78^{\circ} \mathrm{C}$, and then a solution of lithium diisopropylamine in hexanes $(0.73 \mathrm{mmol})$ was added. The solution was warmed to room temperature and stirred for $10 \mathrm{~h}$. The mixture was quenched with saturated aqueous $\mathrm{NH}_{4} \mathrm{Cl}$, and the mixture extracted several times with ether. The combined extracts were dried $\left(\mathrm{MgSO}_{4}\right)$ and concentrated, and the residue was purified by column chromatography $\left(\mathrm{SiO}_{2}\right.$, hexanes-ethyl acetate $=3: 2$ ) to afford a colorless oil ( $29 \mathrm{mg}, 58 \%$ ) which was used without further characterization. To liquid ammonia (ca. $10 \mathrm{~mL}$ ), at $-78^{\circ} \mathrm{C}$ was added lithium metal ( $24 \mathrm{mg}, 3.5 \mathrm{mmol}$ ),

Bioorganic \& Medicinal Chemistry, Vol. 22, No. 1 (January 1, 2014): pg. 303-310. DOI. This article is (C) Elsevier and permission has been granted for this version to appear in e-Publications@Marquette. Elsevier does not grant permission for this article to be further copied/distributed or hosted elsewhere without the express permission from Elsevier. 
followed by $t$-butyl alcohol $(0.05 \mathrm{~mL})$. To this solution was added a solution of the allylic alcohol $(20 \mathrm{mg}, 0.053 \mathrm{mmol})$ in THF $(1 \mathrm{~mL})$. The reaction mixture was stirred at $-78^{\circ} \mathrm{C}$ for $15 \mathrm{~min}$, and then quenched with $\mathrm{NH}_{4} \mathrm{Cl}$, and diluted with ether. The mixture was warmed to room temperature, and water $(10 \mathrm{~mL})$ was added. The mixture was extracted several times with ether followed by extraction with dichloromethane. The combined extracts were dried $\left(\mathrm{MgSO}_{4}\right)$, concentrated and the residue was purified by column chromatography $\left(\mathrm{SiO}_{2}\right.$, hexanes-ethyl acetate $\left.=3: 2\right)$ to afford $\mathbf{2}(9.0 \mathrm{mg}, 60 \%)$ as a colorless solid. Mp 192-194 ${ }^{\circ} \mathrm{C} ;{ }^{1} \mathrm{H}$ NMR $\left(\mathrm{CDCl}_{3}, 400 \mathrm{MHz}\right) \delta 7.15(\mathrm{~d}, \mathrm{~J}$ $=8.4 \mathrm{~Hz}, 1 \mathrm{H}), 6.64(\mathrm{dd}, J=2.8,8.4 \mathrm{~Hz}, 1 \mathrm{H}), 6.58(\mathrm{~d}, J=2.8 \mathrm{~Hz}$, $1 \mathrm{H}), 5.65$ (dd, $J=1.2,2.8 \mathrm{~Hz}, 1 \mathrm{H}), 4.80(\mathrm{br} \mathrm{s}, \mathrm{OH}), 4.32-4.25(\mathrm{~m}$, $2 \mathrm{H}), 2.95-2.80(\mathrm{~m}, 2 \mathrm{H}), 2.40-1.70(\mathrm{~m}, 11 \mathrm{H}), 0.87(\mathrm{~s}, 3 \mathrm{H}) ;{ }^{13} \mathrm{C} N M R$ $\left(\mathrm{CDCl}_{3}, 100 \mathrm{MHz}\right) \delta 155.2,153.5,138.5,133.1,126.4,124.3,126.4$, $124.3,115.5,112.8,60.4,56.8,46.4,44.6,37.4,34.8,31.1,29.7$, $27.9,26.6,16.5$.

\subsection{2. n-Propyl 3-hydroxyestra-1,3,5(10)-triene-17-carboxylate} (4)

To a solution of $3(177 \mathrm{mg}, 0.411 \mathrm{mmol})$ in ethanol $(10 \mathrm{~mL})$ was added an aqueous slurry of Raney-Ni $(60 \%, 0.6 \mathrm{~mL})$. The reaction mixture was stirred under a $\mathrm{H}_{2}$ gas (balloon pressure) for $24 \mathrm{~h}$, after which the mixture was filtered through a bed of filter-aid. The filter bed was washed several times with ethyl acetate, and the filtrate was concentrated under reduced pressure to afford $\mathbf{4}$ as a colorless solid (129 mg, 92\%): mp 151.5-153 ${ }^{\circ} \mathrm{C},[a] 20 \mathrm{D}+69.5$ (c $\left.0.388, \mathrm{CHCl}_{3}\right) ;{ }^{1} \mathrm{H}$ $\operatorname{NMR}\left(\mathrm{CDCl}_{3}, 300 \mathrm{MHz}\right) \delta 7.17(\mathrm{~d}, J=8.4 \mathrm{~Hz}, 1 \mathrm{H}), 6.64(\mathrm{dd}, J=2.8$, $8.5 \mathrm{~Hz}, 1 \mathrm{H}), 6.57(\mathrm{~d}, J=2.7 \mathrm{~Hz}, 1 \mathrm{H}), 4.55(\mathrm{br} \mathrm{s}, \mathrm{OH}), 4.10(\mathrm{dt}, J=$ $10.8,6.7 \mathrm{~Hz}, 1 \mathrm{H}), 4.02(\mathrm{dt}, J=10.8,6.7 \mathrm{~Hz}, 1 \mathrm{H}), 2.90-2.80(\mathrm{~m}, 2 \mathrm{H})$, $2.44(\mathrm{t}, J=9.3 \mathrm{~Hz}, 1 \mathrm{H}), 2.35-2.15(\mathrm{~m}, 3 \mathrm{H}), 1.90-1.75(\mathrm{~m}, 3 \mathrm{H}), 1.68$ (sextet, $J=7.2 \mathrm{~Hz}, 2 \mathrm{H}), 1.55-1.30(\mathrm{~m}, 7 \mathrm{H}), 0.98(\mathrm{t}, J=7.3 \mathrm{~Hz}, 3 \mathrm{H})$, $0.71(\mathrm{~s}, 3 \mathrm{H}) ;{ }^{13} \mathrm{C}$ NMR $\left(\mathrm{CDCl}_{3}, 75 \mathrm{MHz}\right) \delta 174.5,153.5,138.4,132.8$, $126.7,115.4,112.8,66.0,55.6,55.1,44.3,43.9,39.0,38.6,29.8$, 27.8, 26.7, 24.3, 23.7, 22.3, 13.7, 10.9. Anal. Calcd for $\mathrm{C}_{22} \mathrm{H}_{30} \mathrm{O}_{3} \cdot 1 / 2 \mathrm{H}_{2} \mathrm{O}$ : C, 75.18; $\mathrm{H}$ 8.89. Found: $\mathrm{C}, 75.36 ; \mathrm{H}, 8.28$.

Bioorganic \& Medicinal Chemistry, Vol. 22, No. 1 (January 1, 2014): pg. 303-310. DOI. This article is C Elsevier and permission has been granted for this version to appear in e-Publications@Marquette. Elsevier does not grant permission for this article to be further copied/distributed or hosted elsewhere without the express permission from Elsevier. 
NOT THE PUBLISHED VERSION; this is the author's final, peer-reviewed manuscript. The published version may be accessed by following the link in the citation at the bottom of the page.

4.2.3. (20S) 3-(Phenylmethoxy)-19,24-dinorchola-1,3,5(10),16tetraene (6)

To a solution of $5(0.20 \mathrm{~g}, 0.50 \mathrm{mmol})$ in benzene $(10 \mathrm{~mL})$ in a Schlenk flask was added $\mathrm{Rh}\left(\mathrm{PPh}_{3}\right)_{3} \mathrm{Cl}(40 \mathrm{mg}, 0.043 \mathrm{mmol})$. The reaction mixture was cooled with a dry ice-acetone bath, evacuated under high vacuum, and the system refilled to $1 \mathrm{~atm}$ with $\mathrm{H}_{2}$ gas. The mixture was stirred for $7 \mathrm{~h}$ at room temperature, and then the solvent was evaporated. The residue was extracted several times with ether, filtered, and concentrated. The residue was purified by column chromatography $\left(\mathrm{SiO}_{2}\right.$, hexanes $\left.-\mathrm{CH}_{2} \mathrm{Cl}_{2}=10: 1\right)$ to afford $6(138 \mathrm{mg}$, $69 \%$ ) as a colorless solid. Mp 82-83.5 ${ }^{\circ} \mathrm{C},[a] 20 \mathrm{D}+67$ (c 0.74, acetone); ${ }^{1} \mathrm{H}$ NMR $\left(\mathrm{CDCl}_{3}, 300 \mathrm{MHz}\right) \delta 7.46-7.30(\mathrm{~m}, 5 \mathrm{H}), 7.20(\mathrm{~d}, \mathrm{~J}=$ $8.4 \mathrm{~Hz}, 1 \mathrm{H}), 6.78(\mathrm{br} \mathrm{d}, J=8.4 \mathrm{~Hz}, 1 \mathrm{H}), 6.74(\mathrm{br} \mathrm{s}, 1 \mathrm{H}), 5.35$ (br s, $1 \mathrm{H}), 5.04(\mathrm{~s}, 2 \mathrm{H}), 2.94-2.84(\mathrm{~m}, 2 \mathrm{H}), 2.40-2.08(\mathrm{~m}, 4 \mathrm{H}), 2.00-1.87$ $(\mathrm{m}, 3 \mathrm{H}), 1.65-1.28(\mathrm{~m}, 7 \mathrm{H}), 1.09(\mathrm{~d}, J=6.6 \mathrm{~Hz}, 3 \mathrm{H}), 0.89(\mathrm{t}, \mathrm{J}=7.3$ $\mathrm{Hz}, 3 \mathrm{H}), 0.83(\mathrm{~s}, 3 \mathrm{H}) ;{ }^{13} \mathrm{C} \mathrm{NMR}\left(\mathrm{CDCl}_{3}, 75 \mathrm{MHz}\right) \delta 160.2,155.9$, $137.6,136.7,132.9,128.0,127.3,127.0,125.6,120.4,114.4,111.8$, 70.0, 56.4, 47.8, 44.7, 37.8, 35.4, 33.6, 31.3, 30.3, 30.2, 28.2, 27.0, 21.3, 17.1, 12.4. Anal. Calcd for $\mathrm{C}_{29} \mathrm{H}_{36} \mathrm{O}: \mathrm{C}, 86.95 ; \mathrm{H}, 9.06$. Found: $\mathrm{C}$, $86.99 ; \mathrm{H}, 9.12$.

4.2.4. (20S) 3-Hydroxy-19,24-dinorchola-1,3,5(10),16-tetraene (7)

Cleavage of the benzyl ether $6(73 \mathrm{mg}, 0.18 \mathrm{mmol})$ with sodium metal in $n$-butanol was carried out in a fashion similar to the cleavage of 8. Purification of the residue by column chromatography $\left(\mathrm{SiO}_{2}\right.$, hexanes-ethyl acetate gradient $=5: 1$ ) gave unreacted starting material ( $17 \mathrm{mg}$ ) followed by 7 ( $46 \mathrm{mg}, 81 \%$ ) as a colorless solid. $\mathrm{Mp}$ 92-95 ${ }^{\circ} \mathrm{C},[a] 20 \mathrm{D}+86.3$ (c 0.32 , acetone) $;{ }^{1} \mathrm{H}$ NMR (acetone- $\left.d_{6}\right) \delta$ $7.05(\mathrm{~d}, J=8.4 \mathrm{~Hz}, 1 \mathrm{H}), 6.56(\mathrm{dd}, J=2.1,8.4 \mathrm{~Hz}, 1 \mathrm{H}), 6.51(\mathrm{~d}, J=$ $2.1 \mathrm{~Hz}, 1 \mathrm{H}), 5.35(\mathrm{br} \mathrm{s}, 1 \mathrm{H}), 2.82-2.73(\mathrm{~m}, 2 \mathrm{H}), 2.37-2.28(\mathrm{~m}, 1 \mathrm{H})$, 2.22-2.05 (m, 2H), 1.97-1.85 (m, 4H), 1.60-1.26(m, 8H), $1.07(\mathrm{~d}, J$ $=7.2 \mathrm{~Hz}, 3 \mathrm{H}), 0.87(\mathrm{t}, \mathrm{J}=7.5 \mathrm{~Hz}, 3 \mathrm{H}), 0.82(\mathrm{~s}, 3 \mathrm{H}) ;{ }^{13} \mathrm{C} \mathrm{NMR}$ (acetone- $\left.d_{6}\right) \delta 162.5,156.7,139.3,133.2,127.7,122.7,117.1$, 114.7, 58.8, 50.0, 47.1, 40.4, 37.7, 35.8, 33.4, 32.5, 32.2, 30.6, 29.3, 23.2, 19.0, 14.1. Anal. Calcd for $\mathrm{C}_{22} \mathrm{H}_{30} \mathrm{O} \cdot 1 / 6 \mathrm{H}_{2} \mathrm{O}: \mathrm{C}, 84.28 ; \mathrm{H}$, 9.75. Found: $\mathrm{C}, 84.28 ; \mathrm{H}, 9.82$.

Bioorganic \& Medicinal Chemistry, Vol. 22, No. 1 (January 1, 2014): pg. 303-310. DOI. This article is C Elsevier and permission has been granted for this version to appear in e-Publications@Marquette. Elsevier does not grant permission for this article to be further copied/distributed or hosted elsewhere without the express permission from Elsevier. 
4.2.5. (20S) 3-Hydroxy-19,24-Dinorchola-1,3,5(10),16-tetraen23-ol (11)

To a solution of $8(394 \mathrm{mg}, 0.947 \mathrm{mmol})$ in $n$-butanol $(20 \mathrm{~mL})$, at $70{ }^{\circ} \mathrm{C}$, was added sodium metal $(0.87 \mathrm{~g}, 38 \mathrm{mmol})$ in small pieces. After all of the sodium had reacted, the reaction mixture was cooled to room temperature and quenched with water, followed by saturated aqueous $\mathrm{NH}_{4} \mathrm{Cl}$. The reaction mixture was extracted several times with ether, the combined extracts were dried $\left(\mathrm{MgSO}_{4}\right)$ and concentrated. The residue was purified by column chromatography $\left(\mathrm{SiO}_{2}\right.$, hexanesethyl acetate gradient $=4: 1$ to $2: 1$ ) to afford unreacted starting material (91 mg) followed by $\mathbf{1 1}(150 \mathrm{mg}, 49 \%)$ as a colorless solid. Mp 174.5-176 ${ }^{\circ} \mathrm{C},[a] 20 \mathrm{D}+77.5$ (c 1.50, acetone); ${ }^{1} \mathrm{H}$ NMR (acetone$\left.d_{6}\right) \delta 8.15(\mathrm{~s}$, phenol OH$), 7.04(\mathrm{~d}, J=8.4 \mathrm{~Hz}, 1 \mathrm{H}), 6.56(\mathrm{dd}, J=2.7$, $8.4 \mathrm{~Hz}, 1 \mathrm{H}), 6.51(\mathrm{~d}, J=2.7 \mathrm{~Hz}, 1 \mathrm{H}), 5.38(\mathrm{br} \mathrm{s}, 1 \mathrm{H}), 3.64-3.52(\mathrm{~m}$, $3 \mathrm{H}), 2.84-2.74(\mathrm{~m}, 2 \mathrm{H}), 2.42-2.28(\mathrm{~m}, 2 \mathrm{H}), 2.20-2.08(\mathrm{~m}, 1 \mathrm{H})$, $1.96-1.70(\mathrm{~m}, 4 \mathrm{H}), 1.60-1.30(\mathrm{~m}, 7 \mathrm{H}), 1.10(\mathrm{~d}, \mathrm{~J}=7.2 \mathrm{~Hz}, 3 \mathrm{H}), 0.82$ $(\mathrm{s}, 3 \mathrm{H}) ;{ }^{13} \mathrm{C}$ NMR (acetone- $\left.d_{6}\right) \delta 162.8,156.6,139.2,133.0,127.6$, $122.6,117.0,114.6,61.4,58.7,49.9,47.0,43.0,40.3,37.5,33.2$, 32.0, 30.9, 30.5, 29.2, 23.7, 19.0. Anal. Calcd for $\mathrm{C}_{22} \mathrm{H}_{30} \mathrm{O}_{2}$ : C, 80.94; $H, 9.26$. Found: $C, 80.67 ; H, 9.32$.

\subsubsection{7,23-Epoxy-3-(phenylmethoxy)-19,24-dinorchola- $1,3,5(10)$-triene (9)}

To a solution of $8(56 \mathrm{mg}, 0.14 \mathrm{mmol})$ in $\mathrm{CHCl}_{3}(2 \mathrm{~mL})$ was added a drop of concentrated $\mathrm{HCl}$. The mixture was allowed to stand stirred for $24 \mathrm{~h}$ at room temperature, and then passed through a short column of silica gel using hexanes-ethyl acetate as eluent.

Concentration of the eluent gave $9(50 \mathrm{mg}, 89 \%)$ as a colorless oil. $[a] 20 \mathrm{D}+36\left(c\right.$ 1.0, $\left.\mathrm{CH}_{2} \mathrm{Cl}_{2}\right) ;{ }^{1} \mathrm{H}$ NMR $\left(\mathrm{CDCl}_{3}, 300 \mathrm{MHz}\right) \delta 7.46-7.28$ $(\mathrm{m}, 5 \mathrm{H}), 7.22(\mathrm{~d}, J=8.4 \mathrm{~Hz}, 1 \mathrm{H}), 6.87(\mathrm{dd}, J=2.7,8.4 \mathrm{~Hz}, 1 \mathrm{H}), 6.73$ $(\mathrm{d}, J=2.7 \mathrm{~Hz}, 1 \mathrm{H}), 5.04(\mathrm{~s}, 2 \mathrm{H}), 3.87(\mathrm{dt}, J=4.5,7.8 \mathrm{~Hz}, 1), 3.62$ $(\mathrm{dt}, J=6.4,7.8 \mathrm{~Hz}, 1 \mathrm{H}), 2.92-2.82(\mathrm{~m}, 2 \mathrm{H}), 2.38-1.20(\mathrm{~m}, 16 \mathrm{H})$, $1.10(\mathrm{~d}, J=6.9 \mathrm{~Hz}, 3 \mathrm{H}), 0.74(\mathrm{~s}, 3 \mathrm{H}) ;{ }^{13} \mathrm{C} \mathrm{NMR}\left(\mathrm{CDCl}_{3}, 75 \mathrm{MHz}\right) \delta$ $155.8,137.6,136.7,132.8,128.2,127.3,126.9,125.8,114.4,111.8$, 95.5, 70.0, 66.0, 50.0, 48.2, 44.0, 39.3, 36.9, 35.1, 31.3, 31.0, 30.3, 28.1, 26.6, 23.6, 19.0, 15.8. Anal. Calcd for $\mathrm{C}_{29} \mathrm{H}_{36} \mathrm{O}_{2}: \mathrm{C}, 83.61 ; \mathrm{H}$ 8.71. Found: $\mathrm{C}, 83.35 ; \mathrm{H}, 8.75$.

Bioorganic \& Medicinal Chemistry, Vol. 22, No. 1 (January 1, 2014): pg. 303-310. DOI. This article is (C) Elsevier and permission has been granted for this version to appear in e-Publications@Marquette. Elsevier does not grant permission for this article to be further copied/distributed or hosted elsewhere without the express permission from Elsevier. 
NOT THE PUBLISHED VERSION; this is the author's final, peer-reviewed manuscript. The published version may be accessed by following the link in the citation at the bottom of the page.

\subsubsection{7,23-Epoxy-3-hydroxy-19,24-dinorchola-1,3,5(10)- triene (10)}

To a solution of $9(48.9 \mathrm{mg}, 0.118 \mathrm{mmol})$ in methanol/ $\mathrm{CHCl}_{3}$ $(1: 100,6 \mathrm{~mL})$ was added $10 \% \mathrm{Pd}$ on carbon $(5.6 \mathrm{mg})$. The mixture was stirred under $\mathrm{H}_{2}$ (ca. $46 \mathrm{psi}$ ) in a Paar hydrogenation apparatus for $3 \mathrm{~h}$. The catalyst was removed by filtration through filter-aid and the filter bed was washed with copious $\mathrm{CH}_{2} \mathrm{Cl}_{2}$ and the combined filtrates were concentrated. The residue was purified by chromatography $\left(\mathrm{SiO}_{2}\right.$, hexanes-ethyl acetate $=3: 1)$ to afford $\mathbf{1 0}$ as a colorless solid (37.8 mg, 99\%). Mp 172-174 ${ }^{\circ} \mathrm{C} ;{ }^{1} \mathrm{H}$ NMR $\left(\mathrm{CDCl}_{3}, 300 \mathrm{MHz}\right) \delta 7.15(\mathrm{~d}, \mathrm{~J}=$ $8.4 \mathrm{~Hz}, 1 \mathrm{H}), 6.62(\mathrm{dd}, J=2.7,8.4 \mathrm{~Hz}, 1 \mathrm{H}), 6.55(\mathrm{~d}, J=2.7 \mathrm{~Hz}, 1 \mathrm{H})$, $3.87(\mathrm{dt}, J=4.5,7.8 \mathrm{~Hz}, 1 \mathrm{H}), 3.60(\mathrm{dt}, J=6.3,8.1 \mathrm{~Hz}, 1 \mathrm{H}), 2.85-$ $2.75(\mathrm{~m}, 2 \mathrm{H}), 2.35-1.20(\mathrm{~m}, 16 \mathrm{H}), 1.07(\mathrm{~d}, \mathrm{~J}=6.9 \mathrm{~Hz}, 3 \mathrm{H}), 0.70(\mathrm{~s}$, $3 \mathrm{H}) ;{ }^{13} \mathrm{C} \mathrm{NMR}\left(\mathrm{CDCl}_{3}, 75 \mathrm{MHz}\right) \delta 153.3,138.6,133.2,126.6,115.4$, 112.7, 96.0, 66.1, 50.0, 48.2, 43.9, 39.3, 36.8, 35.0, 31.2, 30.8, 30.0, 27.9, 26.4, 23.4, 18.8, 15.6. Anal. Calcd for $\mathrm{C}_{22} \mathrm{H}_{30} \mathrm{O}_{2} \cdot 1 / 4 \mathrm{H}_{2} \mathrm{O}: \mathrm{C}$, 79.83; H 9.29. Found: C, 80.12; H, 9.33.

4.2.8. (20S) 3-Hydroxy-19,24-dinorchola-1,3,5(10),16-tetraen23-al (12)

To a solution of $11(100 \mathrm{mg}, 0.296 \mathrm{mmol})$ in THF $(4 \mathrm{~mL})$ was added a solution of ethyl magnesium bromide in THF $(0.67 \mathrm{~mL}, 1.0 \mathrm{M}$, $0.67 \mathrm{mmol})$. The solution was stirred at room temperature for $15 \mathrm{~min}$, and then solid 1,1'-(azodicarbonyl)dipiperidine $(0.17 \mathrm{~g}, 0.67 \mathrm{mmol}$ ) was added. The reaction mixture was stirred for $1 \mathrm{~h}$, and then quenched with saturated aqueous $\mathrm{NH}_{4} \mathrm{Cl}$ and extracted several times with ether. The combined ethereal extracts were dried $\left(\mathrm{MgSO}_{4}\right)$, concentrated and the residue was purified by column chromatography $\left(\mathrm{SiO}_{2}\right.$, hexanes-ethyl acetate $\left.=5: 1\right)$ to afford $\mathbf{1 2}$ as a colorless solid (66 mg, 66\%). Mp 168.5-171 ${ }^{\circ} \mathrm{C},[a] 20 \mathrm{D}+78$ (c 0.80, acetone); ${ }^{1} \mathrm{H}$ NMR (acetone- $\left.d_{6}, 300 \mathrm{MHz}\right) \delta 9.66(\mathrm{t}, J=2.1 \mathrm{~Hz}, 1 \mathrm{H}), 7.06(\mathrm{~d}, J=$ $8.4 \mathrm{~Hz}, 1 \mathrm{H}), 6.57(\mathrm{dd}, J=2.5,8.4 \mathrm{~Hz}, 1 \mathrm{H}), 6.51(\mathrm{~d}, J=2.5 \mathrm{~Hz}, 1 \mathrm{H})$, $5.46(\mathrm{br} \mathrm{s}, 1 \mathrm{H}), 2.90-2.75(\mathrm{~m}, 4 \mathrm{H}), 2.62$ (ddd, J = 1.8, 5.7, $16.2 \mathrm{~Hz}$, $1 \mathrm{H}), 2.44-2.30(\mathrm{~m}, 2 \mathrm{H}), 2.26-2.10(\mathrm{~m}, 2 \mathrm{H}), 1.98-1.86(\mathrm{~m}, 3 \mathrm{H})$, $1.60-1.34(\mathrm{~m}, 5 \mathrm{H}), 1.16(\mathrm{~d}, J=7.2 \mathrm{~Hz}, 3 \mathrm{H}), 0.88(\mathrm{~s}, 3 \mathrm{H}) ;{ }^{13} \mathrm{C}$ NMR (acetone- $\left.d_{6}, 75 \mathrm{MHz}\right) \delta 203.2,161.4,156.8,139.5,133.3,127.9$, $124.6,117.2,114.8,59.2,53.1,50.2$, 47.2, 40.5, 37.7, 33.6, 32.3,

Bioorganic \& Medicinal Chemistry, Vol. 22, No. 1 (January 1, 2014): pg. 303-310. DOI. This article is CC Elsevier and permission has been granted for this version to appear in e-Publications@Marquette. Elsevier does not grant permission for this article to be further copied/distributed or hosted elsewhere without the express permission from Elsevier. 
NOT THE PUBLISHED VERSION; this is the author's final, peer-reviewed manuscript. The published version may be accessed by following the link in the citation at the bottom of the page.

30.7, 29.7, 29.4, 23.8, 19.3. Anal. Calcd for $\mathrm{C}_{22} \mathrm{H}_{28} \mathrm{O}_{2}: \mathrm{C}, 81.44 ; \mathrm{H}$, 8.70. Found: $\mathrm{C}, 81.21 ; \mathrm{H}, 8.54$.

4.2.9. 17,23-Epoxy-3-hydroxy-19-norchola-1,3,5(10)-triene (13)

To a solution of 12 (45.9 $\mathrm{mg}, 0.142 \mathrm{mmol})$ in THF (7 mL) at $0{ }^{\circ} \mathrm{C}$ was added a solution of methyl magnesium bromide in ether $(0.10 \mathrm{~mL}, 3.0 \mathrm{M}, 0.30 \mathrm{mmol})$. The reaction mixture was stirred for $3 \mathrm{~h}$, and then quenched with saturated aqueous $\mathrm{NH}_{4} \mathrm{Cl}(15 \mathrm{~mL})$. The mixture was extracted several times with $\mathrm{CH}_{2} \mathrm{Cl}_{2}$ and the combined extracts were dried $\left(\mathrm{MgSO}_{4}\right)$ and concentrated. The residue was purified by chromatography $\left(\mathrm{SiO}_{2}\right.$, hexanes-ethyl acetate $\left.=5: 1\right)$ to afford 13 as a colorless solid (44 mg, 92\%). Analysis of the product by ${ }^{1} \mathrm{H}$ NMR spectroscopy indicated this to be a $1: 1$ mixture of diastereomers. Mp 248-251 ${ }^{\circ} \mathrm{C},{ }^{1} \mathrm{H}$ NMR $\left(\mathrm{CDCl}_{3}, 300 \mathrm{MHz}\right) \delta 7.15(\mathrm{~d}, \mathrm{~J}$ $=8.4 \mathrm{~Hz}, 1 \mathrm{H}), 6.62(\mathrm{dd}, J=2.7,8.4 \mathrm{~Hz}, 1 \mathrm{H}), 6.56(\mathrm{~d}, J=2.7 \mathrm{~Hz}$, $1 \mathrm{H}), 4.18-4.07(\mathrm{~m}, 1 \mathrm{H}), 3.85-3.74(\mathrm{~m}, 1 \mathrm{H}), 2.85-2.75(\mathrm{~m}, 2 \mathrm{H})$, 2.35-1.20 (m, 15H), $1.23 \& 1.20(2 \times \mathrm{d}, \mathrm{J}=5.7 \mathrm{~Hz}, 3 \mathrm{H}$ total $), 1.07 \&$ $1.05(2 \times \mathrm{d}, \mathrm{J}=6.9 \mathrm{~Hz}, 3 \mathrm{H}), 0.72 \& 0.66(2 \times \mathrm{s}, 3 \mathrm{H}$ total $) ;{ }^{13} \mathrm{C} \mathrm{NMR}$ $\left(\mathrm{CDCl}_{3}, 75 \mathrm{MHz}\right) \delta 153.3,138.6,133.2,126.6,115.4,112.7,97.1$ [95.8], 73.6 [71.3], 49.85 [49.80], 48.8, 47.1, 45.4, 43.9 [43.8], $43.5,39.3[39.2], 36.2,34.5,32.3,31.2[30.9], 30.6[30.1], 27.8$, 26.5 [26.4], 23.5 [23.4], 21.6, 19.2 [18.9], 16.3 [14.9]. Anal. Calcd for $\mathrm{C}_{23} \mathrm{H}_{32} \mathrm{O}_{2} \cdot 1 / 2 \mathrm{H}_{2} \mathrm{O}: \mathrm{C}, 79.04 ; \mathrm{H}, 9.52$. Found: $\mathrm{C}, 79.34 ; \mathrm{H}, 9.57$.

\subsubsection{0. cis- and trans-4-(4'-Hydroxycyclohexyl)phenol (14)}

To a solution of 4-(4'-hydroxyphenyl)cyclohexanone (50 mg, $0.26 \mathrm{mmol}$ ) in methanol $(1 \mathrm{~mL})$ was added $\mathrm{NaBH}_{4}(15 \mathrm{mg}, 4.0 \mathrm{mmol})$. The reaction mixture was stirred for $30 \mathrm{~min}$, and then diluted with water. The mixture was extracted several times with ethyl acetate and the combined extracts were concentrated and purified by column chromatography $\left(\mathrm{SiO}_{2}\right.$, hexanes-ethyl acetate $\left.=2: 1\right)$ to afford cis-14 (5.0 mg, 10\%) followed by trans-15 (43 mg, 86\%) both as colorless solids. Cis-14: ${ }^{1} \mathrm{H} N M R\left(\mathrm{CD}_{3} \mathrm{OD}, 400 \mathrm{MHz}\right) \delta 7.04-6.69\left(\mathrm{AA}^{\prime} \mathrm{BB}^{\prime}, J_{A B}=\right.$ $8.8 \mathrm{~Hz}, 4 \mathrm{H}$ ) , 4.02 (narrow $\mathrm{t}, J=2.8 \mathrm{~Hz}, 1 \mathrm{H}), 2.50-2.40(\mathrm{~m}, 1 \mathrm{H})$,

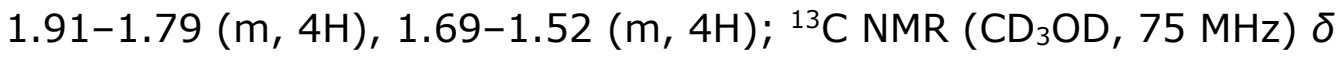
156.5, 140.1, 128.8, 116.1, 66.5, 44.5, 34.0, 29.4. Trans-15: ${ }^{1} \mathrm{H}$ NMR $\left(\mathrm{CD}_{3} \mathrm{OD}, 400 \mathrm{MHz}\right) \delta 7.01-6.68\left(\mathrm{AA}^{\prime} \mathrm{BB}^{\prime}, J_{A B}=8.4 \mathrm{~Hz}, 4 \mathrm{H}\right), 3.58(\mathrm{tt}, \mathrm{J}$

Bioorganic \& Medicinal Chemistry, Vol. 22, No. 1 (January 1, 2014): pg. 303-310. DOI. This article is @ Elsevier and permission has been granted for this version to appear in e-Publications@Marquette. Elsevier does not grant permission for this article to be further copied/distributed or hosted elsewhere without the express permission from Elsevier. 
NOT THE PUBLISHED VERSION; this is the author's final, peer-reviewed manuscript. The published version may be accessed by following the link in the citation at the bottom of the page.

$=4.4,10.6 \mathrm{~Hz}, 1 \mathrm{H}), 2.39(\mathrm{tt}, \mathrm{J}=3.5,11.8 \mathrm{~Hz}, 1 \mathrm{H}), 2.06-1.99(\mathrm{~m}$, $2 \mathrm{H}), 1.87-1.79(\mathrm{~m}, 2 \mathrm{H}), 1.56-1.33(\mathrm{~m}, 4 \mathrm{H})$.

\subsubsection{4-(4-Hydroxyphenyl)-cyclohexanone oxime (16)}

To a solution of 4-(4'-hydroxyphenyl)cyclohexanone $(50 \mathrm{mg}$, $0.26 \mathrm{mmol})$, hydroxylamine hydrochloride $(36.6 \mathrm{mg}, 0.526 \mathrm{mmol})$ in ethanol ( $5 \mathrm{~mL}$ ) was added Amberlyst ( $56 \mathrm{mg}$ ). After stirring for $2 \mathrm{~h}$, the mixture was filtered, and the filtrate concentrated. The residue was partitioned between water and ethyl acetate, and the organic layer was concentrated and dried to give $( \pm)-\mathbf{1 6}(44 \mathrm{mg}, 82 \%)$ as a colorless solid. Mp $172-175{ }^{\circ} \mathrm{C} .{ }^{1} \mathrm{H}$ NMR $\left(\mathrm{CD}_{3} \mathrm{OD}, 400 \mathrm{MHz}\right) \delta 7.03-$ $6.69\left(\mathrm{AA}^{\prime} \mathrm{BB}^{\prime}, J_{A B}=8.8 \mathrm{~Hz}, 4 \mathrm{H}\right), 4.02($ narrow t $\mathrm{J}=2.8 \mathrm{~Hz}, 1 \mathrm{H}), 2.0-$ $2.40(\mathrm{~m}, 1 \mathrm{H}), 1.91-1.79(\mathrm{~m}, 4 \mathrm{H}), 1.69-1.52(\mathrm{~m}, 4 \mathrm{H}) ;{ }^{13} \mathrm{C} \mathrm{NMR}$ $\left(\mathrm{CD}_{3} \mathrm{OD}, 75 \mathrm{MHz}\right) \delta 161.0,156.8,138.4,128.7,116.3,44.3,36.0$, 34.7, 33.0, 25.2. HRMS (ESI): $\mathrm{m} / z$ calcd for $\mathrm{C}_{12} \mathrm{H}_{15} \mathrm{NO}_{2}+\mathrm{Na}^{+}[\mathrm{M}+\mathrm{Na}]^{+}$ 228.0995, found 228.0997 .

\subsubsection{2. cis-1-Hydroxymethyl-4-(4'-hydroxyphenyl)-cycloheptane} (18)

To a solution of $( \pm)-\mathbf{1 7}(75 \mathrm{mg}, 0.35 \mathrm{mmol})$ in methanol (15 $\mathrm{mL}$ ) in a heavy walled reaction vessel, was added a catalytic amount of $20 \% \mathrm{Pd} / \mathrm{C}$. The mixture was stirred under $\mathrm{H}_{2}$ pressure $(45 \mathrm{psi}$ ) for $75 \mathrm{~min}$ and then the reaction mixture was filtered through the pad of celite. The filtrate was concentrated and the residue was purified by column chromatography $\left(\mathrm{SiO}_{2}\right.$, hexanes-ethyl acetate $\left.=65: 35\right)$ to afford $( \pm)-18(38 \mathrm{mg}, 50 \%)$ as a colorless solid. Mp 60-61 ${ }^{\circ} \mathrm{C} ;{ }^{1} \mathrm{H}$ $\operatorname{NMR}\left(\mathrm{CDCl}_{3}, 300 \mathrm{MHz}\right) \delta 7.06$ and $6.75\left(\mathrm{AA}^{\prime} \mathrm{BB}^{\prime}, J_{A B}=9.0 \mathrm{~Hz}, 4 \mathrm{H}\right)$, $3.48(\mathrm{~d}, \mathrm{~J}=6.3 \mathrm{~Hz}, 1 \mathrm{H}), 2.59-2.58(\mathrm{~m}, 1 \mathrm{H}), 1.95-1.08(\mathrm{~m}, 13 \mathrm{H}) ;{ }^{13} \mathrm{C}$ NMR $\left(\mathrm{CD}_{3} \mathrm{OD}, 75 \mathrm{MHz}\right) \delta 127.9,115.3,68.6,46.1,41.4,38.8,33.1$, $31.6,28.5,27.5$. HRMS (ESI): $\mathrm{m} / z$ calcd for $\mathrm{C}_{14}-\mathrm{H}_{20} \mathrm{O}_{2}+\mathrm{Na}^{+}[\mathrm{M}+\mathrm{Na}]^{+}$ 243.1356, found 243.1356 .

\subsubsection{5-[(1E)-2-(4-Hydroxyphenyl)ethenyl]-2-furanmethanol} (20)

A solution of methyl 5-bromo-2-furanoate $(1.03 \mathrm{~g}, 5.02 \mathrm{mmol})$, 4-acetoxystyrene $(0.97 \mathrm{~g}, 6.0 \mathrm{mmol})$, palladium acetate $(0.01 \mathrm{~g}, 0.05$ $\mathrm{mmol})$, tri-o-tolylphosphine $(0.03 \mathrm{~g}, 0.2 \mathrm{mmol})$, and triethylamine (3

Bioorganic \& Medicinal Chemistry, Vol. 22, No. 1 (January 1, 2014): pg. 303-310. DOI. This article is CC Elsevier and permission has been granted for this version to appear in e-Publications@Marquette. Elsevier does not grant permission for this article to be further copied/distributed or hosted elsewhere without the express permission from Elsevier. 
$\mathrm{mL}$ ) was heated under nitrogen in a sealed heavy-walled Pyrex tube at $100{ }^{\circ} \mathrm{C}$ for $24 \mathrm{~h}$. The reaction mixture was cooled, diluted with water and dichloromethane. The dichloromethane layer was separated, washed with water, and dried $\left(\mathrm{MgSO}_{4}\right)$, and the residue was purified by column chromatography $\left(\mathrm{SiO}_{2}\right.$, hexanes-ethyl acetate $=4: 1$ ) to afford 19 (350 mg, 24\%), a pale yellow solid. Mp $110.5-112{ }^{\circ} \mathrm{C} ;{ }^{1} \mathrm{H}$ $\operatorname{NMR}\left(\mathrm{CDCl}_{3}, 300 \mathrm{MHz}\right) \delta 7.51(\mathrm{~d}, \mathrm{~J}=8.1,2 \mathrm{H}), 7.27(\mathrm{~d}, \mathrm{~J}=16.5 \mathrm{~Hz}$, $1 \mathrm{H}), 7.20(\mathrm{~d}, J=3.6 \mathrm{~Hz}, 1 \mathrm{H}), 7.10(\mathrm{~d}, J=8.1 \mathrm{~Hz}, 2 \mathrm{H}), 6.86(\mathrm{~d}, J=$ $16.5 \mathrm{~Hz}, 1 \mathrm{H}), 6.45(\mathrm{~d}, J=3.6 \mathrm{~Hz}, 1 \mathrm{H}), 3.92(\mathrm{~s}, 3 \mathrm{H}, \mathrm{OMe}), 2.32(\mathrm{~s}, 3 \mathrm{H}$, OAc). This product was used in the next step without further characterization. To a solution of diester $(50 \mathrm{mg}, 0.17 \mathrm{mmol})$ in anhydrous ether $(1 \mathrm{~mL})$ at $0{ }^{\circ} \mathrm{C}$, was slowly added a solution of lithium aluminium hydride $(0.52 \mathrm{~mL}, 1.0 \mathrm{M}$ in THF, $0.52 \mathrm{mmol})$. Solution was stirred for $3 \mathrm{~h}$ at $0{ }^{\circ} \mathrm{C}$ and then saturated aqueous sodium bicarbonate $(2 \mathrm{~mL})$ was added follow by dilute sodium hydroxide. The mixture was warmed to room temperature, extracted several times with ethyl acetate. The combined extracts were dried $\left(\mathrm{MgSO}_{4}\right)$, concentrated and the residue was purified by column chromatography $\left(\mathrm{SiO}_{2}\right.$, hexanesethyl acetate $=1: 1)$ gave $20(28 \mathrm{mg}, 74 \%)$ as a colorless solid. Mp 129-131 ${ }^{\circ} \mathrm{C} ;{ }^{1} \mathrm{H}$ NMR (acetone- $d_{6}, 300 \mathrm{MHz}$ ) $\delta 8.59$ (br s, 1H), 7.40 $(\mathrm{d}, J=9.0 \mathrm{~Hz}, 2 \mathrm{H}), 6.97-6.79(\mathrm{~m}, 4 \mathrm{H}), 6.30(\mathrm{~s}, 2 \mathrm{H}), 4.57(\mathrm{br} \mathrm{s}, 2 \mathrm{H})$, 3.05 (br s, $1 \mathrm{H}$ ); ${ }^{13} \mathrm{C}$ NMR (acetone- $\left.d_{6}, 75 \mathrm{MHz}\right) \delta 158.2,155.9,154.1$, 129.7, 128.6, 127.4, 116.5, 114.9, 109.9, 109.4, 57.4. HRMS (ESI): $\mathrm{m} / z$ calcd for $\mathrm{C}_{13} \mathrm{H}_{12} \mathrm{O}_{3}+\mathrm{Na}^{+}[\mathrm{M}+\mathrm{Na}]^{+} 239.0679$, found 239.0681 .

\subsection{Fluorescence polarization}

The assay was developed based on a commercially available kit from Invitrogen. ${ }^{15}$ Assays were run on a BMG POLARstar Galaxy reader with acquisition parameters as follows: 200 flashes, positioning delay $1.0 \mathrm{~s}, K$ factor $\leq 1.1$ and $\geq 0.9$, excitation filter of $485 \pm 5 \mathrm{~nm}$ and emission filter of $520 \pm 15 \mathrm{~nm}$. For the $\mathrm{IC}_{50}$ determinations the [ER-a] was $30 \mathrm{nM}$ and the [FITC-estradiol tracer] ([Tr]) was $10 \mathrm{nM}$. Sample volume was $150 \mu \mathrm{L}$. For each experiment the polarization was calibrated with a sample of FITC set at $20 \mathrm{mP}$. All proper blanks were used, including water for the FITC samples and blank samples containing only $30 \mathrm{nM}$ ERa protein for the remaining data points. All protein samples contained $1 \%$ DMSO- $d_{6}$, the maximum amount tolerated as stated by the supplier of the ERa protein, Invitrogen, to

Bioorganic \& Medicinal Chemistry, Vol. 22, No. 1 (January 1, 2014): pg. 303-310. DOI. This article is @ Elsevier and permission has been granted for this version to appear in e-Publications@ Marquette. Elsevier does not grant permission for this article to be further copied/distributed or hosted elsewhere without the express permission from Elsevier. 
ensure the solubility of all hydrophobic compounds investigated. The $K_{d}$ of the FITC-tagged estradiol for ER-a was determined by non-linear least squares fitting of the titration curve data to the following equation (where $\mathrm{Tr}_{\mathrm{o}}$ is the F-E2 tracer):

$$
\begin{aligned}
& \Delta \mathrm{FP}=\frac{\mathrm{FP}_{\max }}{2\left[\mathrm{Tr}_{0}\right]}\left(K_{\mathrm{d}}+\left[\mathrm{Tr}_{0}\right]+[\mathrm{ER} a]\right) \\
& -\left\{\left(K_{\mathrm{d}}+\left[\mathrm{Tr}_{0}\right]+[\mathrm{ER} a]\right)^{2}-4\left[\mathrm{Tr}_{0}\right]\right\}+[\mathrm{ER} a]
\end{aligned}
$$

\subsection{Cell-based ERa and ER $\beta$ assays}

ERa and ER $\beta$ assay kits for cell-based assays (Indigo Biosciences) allowed for investigation into the functional activity (i.e., agonist and/or antagonist) of the ligands identified to bind based on the initial fluorescence polarization displacement assay. Briefly, the cells contained a luciferase reporter gene that was functionally linked to either the ERa or ERß-responsive promoter. By quantifying the luciferase expression via luminescence, the change in ER activity could be quantified. 1-2 mM stocks of the ligands were prepared in DMSO- $d_{6}$ and diluted to final concentrations ranging from $3.2 \mathrm{nM}$ to $2 \mu \mathrm{M}$, using the Compound Screening Medium provided in the kit. For the agonist assay, the cells were prepared by warming to $37^{\circ} \mathrm{C}$, plated, then the chemicals added. For the antagonist assay, the cells were prepared as above with the addition of E2 (for ERa $3.2 \mathrm{nM}$ was added, approximating an $\mathrm{IC}_{75}$; and, for $\mathrm{ER} \beta 160 \mathrm{pM}$ was added, approximating an $\left.\mathrm{IC}_{80}\right)$. The cells were then plated, and the chemicals added. All plates were incubated in a cell culture incubator at $37{ }^{\circ} \mathrm{C}$ and $5 \% \mathrm{CO}_{2}$ for $22 \mathrm{~h}$. Each assay was performed in duplicate. Luminescence was characterized after removal of the incubating media and introduction of the Detection Substrate using a Molecular Devices SpectraMax M5 microplate reader. Data was fitted using GraphPad Prism and fit to the dose-response (four paramter) equation as follows.

$$
y=\frac{\text { bottom }-(\text { top }- \text { bottom })}{\left(1+10^{\left(\log C_{50}-x\right) \text { Hillslope }}\right)}
$$

Bioorganic \& Medicinal Chemistry, Vol. 22, No. 1 (January 1, 2014): pg. 303-310. DOI. This article is (C) Elsevier and permission has been granted for this version to appear in e-Publications@Marquette. Elsevier does not grant permission for this article to be further copied/distributed or hosted elsewhere without the express permission from Elsevier. 
NOT THE PUBLISHED VERSION; this is the author's final, peer-reviewed manuscript. The published version may be accessed by following the link in the citation at the bottom of the page.

\subsection{Molecular docking}

Ligand structures were drawn in PC Spartan Plus (Wavefunction) and three dimensional (3D) conformation was then optimized using semiempirical Austin Model 1 (AM1) calculations. Since compound 13 was afforded as a pair of diastereomers both were modeled and docked. The AM1 calculations provided geometries and bond distances for subsequent docking. AutoDock Tools (ADT) was used prepare the ligand files according to AutoDock requirements and assign Gasteiger charges.

The ERa receptor for agonist ( $\mathrm{pdb}$ code $1 \mathrm{ere})^{4}$ and antagonist ( $p d b$ code 1 err) ${ }^{32}$ conformations were prepared for docking calculations using the ' $A$ ' chain. The ER $\beta$ receptor for agonist ( $p d b$ code $2 \mathrm{jj} 3)^{33}$ and antagonist ( $p d b$ code $\left.1 / 2 \mathrm{j}\right)^{34}$ conformations were prepared for docking calculations using the ' $A$ ' chain. ADT was used to further prepare the ER receptor files by adding hydrogen atoms and adding partial charges to each atom of the protein. The grid box was centered on the co-crystallized ligand, drawn to a box to incorporate amino acids Arg394, Glu353, and His524 for ERa and Arg346, Glu305, and His475 for ER $\beta$, then the estradiol ligand was removed. ${ }^{35}$ AutoDock ( $v$. 4.2) calculations were performed with default parameters, except with 100 genetic algorithmic runs and 2,500,000 evaluations per run. ${ }^{35-39}$

\section{Acknowledgments}

This work was supported by an NIH Instrumentation Grant (S10 RR019012). W.A.D. acknowledges financial support from the National Institutes of Health (GM-42641) and the National Science Foundation (CHE-0415771). D.S.S. acknowledges financial support from NIH Grants AI101975 and HL112639, and the use of resources at the Children's Environmental Health Sciences Core Center (funded by National Institute of Environmental Health Sciences, P30 ES004184) at the University of Wisconsin Milwaukee. Dr. Phani Kumar Pullela is gratefully acknowledged for providing the synthesized F-E2 tracer. High-resolution mass spectra were obtained at the COSMIC lab at Old Dominion University.

Bioorganic \& Medicinal Chemistry, Vol. 22, No. 1 (January 1, 2014): pg. 303-310. DOI. This article is C Elsevier and permission has been granted for this version to appear in e-Publications@Marquette. Elsevier does not grant permission for this article to be further copied/distributed or hosted elsewhere without the express permission from Elsevier. 
NOT THE PUBLISHED VERSION; this is the author's final, peer-reviewed manuscript. The published version may be accessed by following the link in the citation at the bottom of the page.

\section{References and notes}

1. Manas ES, Xu ZB, Unwalla RJ, Somers WS. Structure. 2004;12:2197.

2. Levin ER. Mol Endocrinol. 2005;19:1951.

3. Li X, Huang J, Yi P, Bambara RA, Hilf R, Muyan M. Mol Cell Biol. 2004;24:7681.

4. Brzozowski AM, Pike ACW, Dauter Z, Hubbard RE, Bonn T, Engstrom O, Ohman L, Greene GL, Gustafsson JA, Carlquist M. Nature. 1997;389:753.

5. Payne J, Scholz M, Kortenhamp A. Environ Health Perspect. 2001;109:391.

6. Blair RM, Fang $\mathrm{H}$, Branham WS, Hass BS, Dial SL, Moland $\mathrm{CL}$, Tong W, Shi

L, Perking R, Sheehan DM. Toxicol Sci. 2000;54:138.

7. Deroo BJ, Korach KS. J Clin Invest. 2006;116:561.

8. Colborn T, Saal FS, Soto AM. Environ Health Perspect. 1993;101:378.

9. Brody JG, Rudel RA. Environ Health Perspect. 2003;111:1007.

10. Tice R. National Toxicology Program. National Institute of Environmental Health Sciences. NIH, U.S. Dept. of Health and Human Services; 2001. Biomolecular Screening Branch. July 5, 2013

( http://www.niehs.nih.gov/research/atniehs/labs/bmsb/index.cfm)

11. Nasir MS, Jolley ME. Comb Chem High Throughput Screening. $1999 ; 2: 177$.

12. Burke TJ, Loniello KR, Beebe JA, Ervin KM. Comb Chem High Throughput Screening. 2003;6:183.

13. Ohno K, Fukushima T, Santa T, Waizumi N, Tokuyama H, Maeda M, Imai K. Anal Chem. 2002;74:4391.

14. Suzuki S, Ohno K, Santa T, Imai K. Anal Sci. 2003;19:1103.

15. Parker GJ, Law TL, Lenoch FJ, Bolger RE. J Biomol Screen. 2000;5:77.

16. Costache AD, Pullela PK, Kashi P, Tomasiewicz H, Sem DS. Mol Endocrinol. 2005;19:2979.

17. Bolger R, Wiese TE, Ervin K, Nestich S, Checovich W. Environ Health Perspect. 1998;106:551.

18. Shoichet BK. Nature. 2004;432:862.

19. Irwin JJ, Shoichet BK. J Chem Inf Model. 2005;45:177.

20. Cavasotto CN, Orry AJW. Curr Top Med Chem. 2007;7:1006.

21. Suresh PS, Kumar A, Kumar R, Sihn VP. J Mol Graphics Modell. $2008 ; 26: 845$.

22. Cross JB, Thompson DC, Rai BK, Baber JC, Fan KY, Hu Y, Humblet C. J Chem Inf Model. 2009;49:1455.

23. De Riccardis F, Meo D, Izzo I, Di Filippo M, Casapullo A. Eur J Org Chem. 1998: 1965.

24. Lam HYP, Begleiter A, Goldenberg GJ. J Med Chem. 1979;22:200.

25. Li PK, Murakata C, Akinaga S. 6,288,050, 2001. US Patent.

26. He Z, Donaldson WA, Yi CS. Org Lett. 2003;5:1567.

Bioorganic \& Medicinal Chemistry, Vol. 22, No. 1 (January 1, 2014): pg. 303-310. DOI. This article is (C Elsevier and permission has been granted for this version to appear in e-Publications@Marquette. Elsevier does not grant permission for this article to be further copied/distributed or hosted elsewhere without the express permission from Elsevier. 
27. Frigoli M, Mehl GH. Eur J Org Chem. 2004:636.DeOrazio RJ, Nikam SS, Scott IL, Sherer BA, Wise LD. 01/81295 A1. PCT Int Appl WO. 2001

28. Indigo Biosciences. Human Estrogen Receptor Technical Manual

29. Pandey RK, Wang L, Wallock NJ, Lindeman S, Donaldson WA. J Org Chem. 2008;73:7236.

30. van Lipzig $M M H$, ter Laak AM, Jongegan A, Vermeulen NPE, Wamelink M, Geerke D, Meerman JHN. J Med Chem. 2004;47:1018.

31. Miteva MA, Lee WH, Montes MO, Villoutreix BO. J Med Chem. 2005;48:6012.

32. Norman BH, Richardson TI, Dodge JA, Pfeifer LA, Durst GL, Wang Y, Durbin JD, Krishnan V, Dinn SR, Liu S, Reilly JE, Ryter KT. Bioorg Med Chem Lett. 2007; 17:5082.

33. Shiau AK, Barstad D, Radek JT, Meyers MJ, Nettles KW, Katzenellenbogen BS, Katzellenbogen JA, Agard DA, Greene GL. Nat Struct Biol. 2002; 9:359.

34. Tuccinardi T, Bertini S, Martinelli A, Minutolo F, Ortore G, Placanica G, Prota G, Rapposelli S, Carleson KE, Katzenellenbogen JA, Macchia M. J Med Chem. 2006;49:5001.

35. Morris GM, Huey R, Lindstrom W, Sanner MF, Belew RK, Goodsell DS, Olson AJ. J Comput Chem. 2009;30:2785.

36. Morris GM, Goodsell DS, Halliday RS, Huey R, Hart WE, Belew RK, Olson AJ. J Comput Chem. 1998;19:1639.

37. Goodsell DS, Morris GM, Olson AJ. J Mol Recognit. 1996;9:1.

38. Huey R, Morris BM, Olson AJ, Goodsell DS. J Comput Chem. 2007;28:1145.

39. Li Z, Zhang H, Gibson M, Li J. Toxicol In Vitro. 2012;26:769.

\section{Footnotes}

\section{A. Supplementary data}

Supplementary data associated with this article can be found, in the online version, at http://dx.doi.org/10.1016/j.bmc.2013.11.024.

Bioorganic \& Medicinal Chemistry, Vol. 22, No. 1 (January 1, 2014): pg. 303-310. DOI. This article is @ Elsevier and permission has been granted for this version to appear in e-Publications@Marquette. Elsevier does not grant permission for this article to be further copied/distributed or hosted elsewhere without the express permission from Elsevier. 
NOT THE PUBLISHED VERSION; this is the author's final, peer-reviewed manuscript. The published version may be accessed by following the link in the citation at the bottom of the page.

\section{Supplementary Material 1}

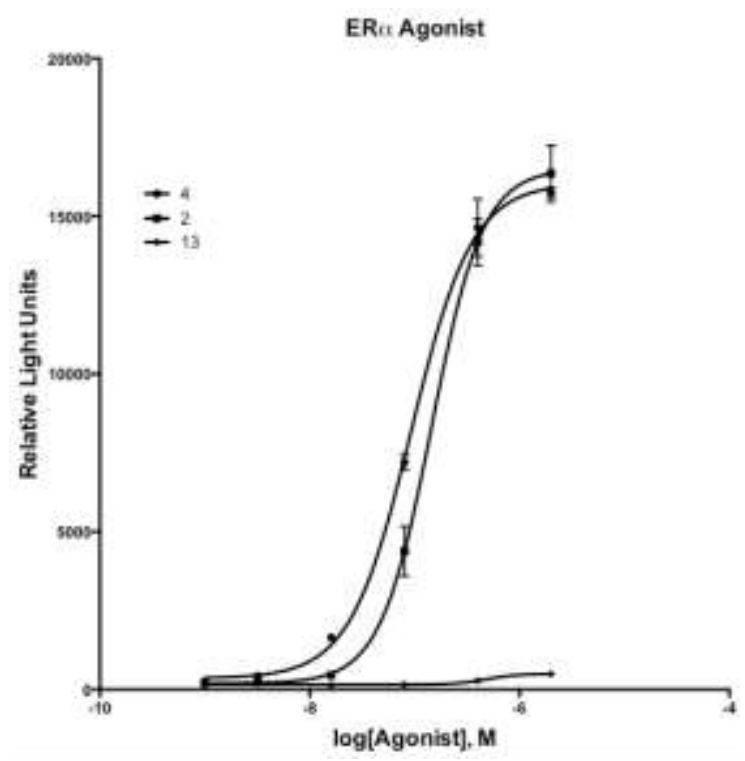

Supplementary Figure S1. Cell-based ERa assay data including regression for ligands that showed agonist activity.

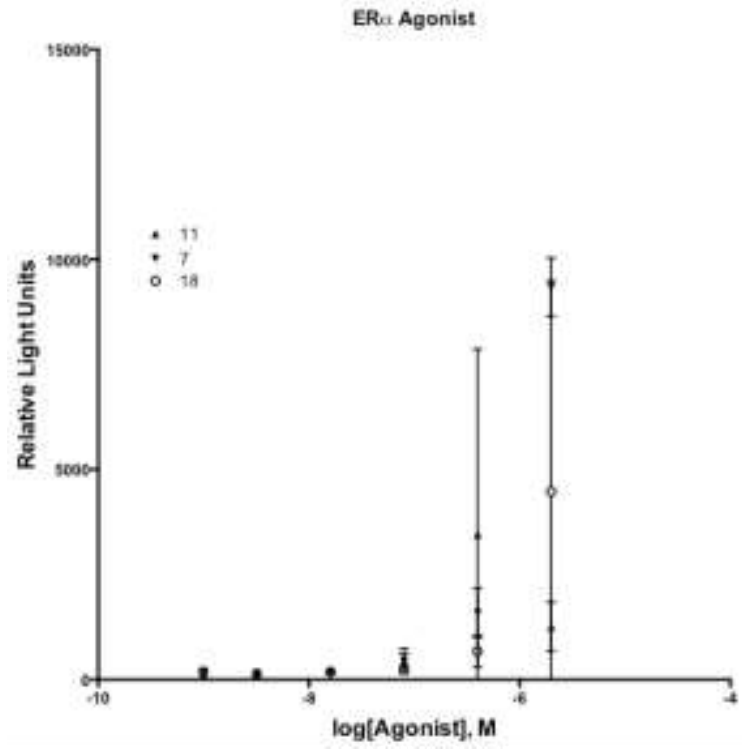

Supplementary Figure S2. Cell-based ERa agonist assay data for chemicals without sufficient quality data to determine activity.

Bioorganic \& Medicinal Chemistry, Vol. 22, No. 1 (January 1, 2014): pg. 303-310. DOI. This article is C Elsevier and permission has been granted for this version to appear in e-Publications@Marquette. Elsevier does not grant permission for this article to be further copied/distributed or hosted elsewhere without the express permission from Elsevier. 
NOT THE PUBLISHED VERSION; this is the author's final, peer-reviewed manuscript. The published version may be accessed by following the link in the citation at the bottom of the page.

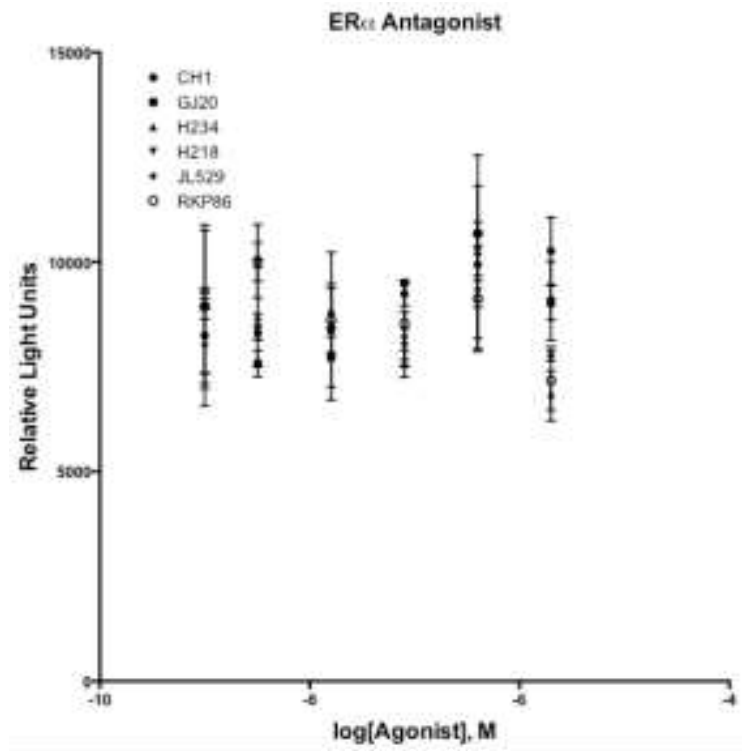

Supplementary Figure S3. Cell-based ERa antagonist assay data for chemicals without sufficient quality data to determine activity.

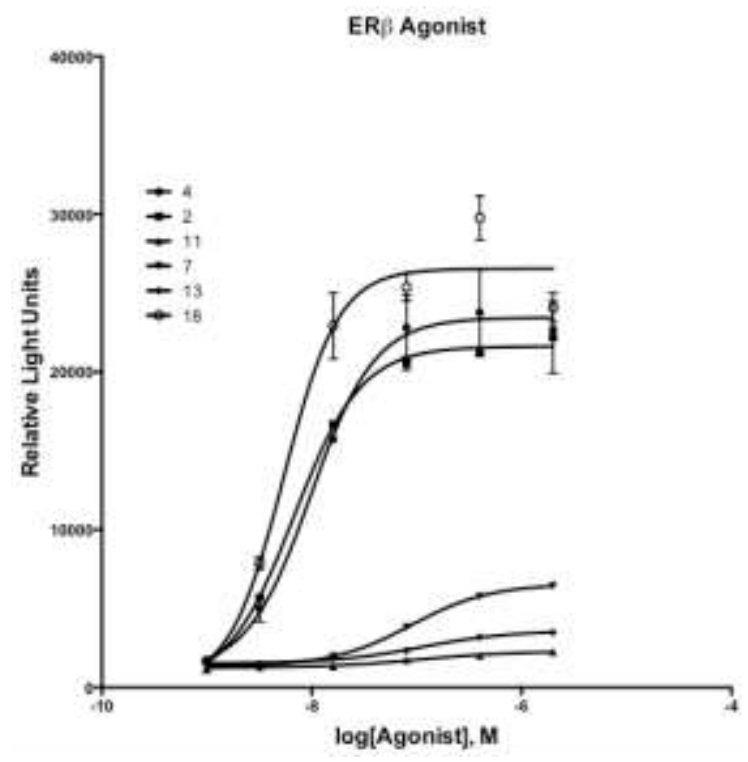

Supplementary Figure S4. Cell-based ERß agonist assay data. for ligands that showed antagonist activity 
NOT THE PUBLISHED VERSION; this is the author's final, peer-reviewed manuscript. The published version may be accessed by following the link in the citation at the bottom of the page.

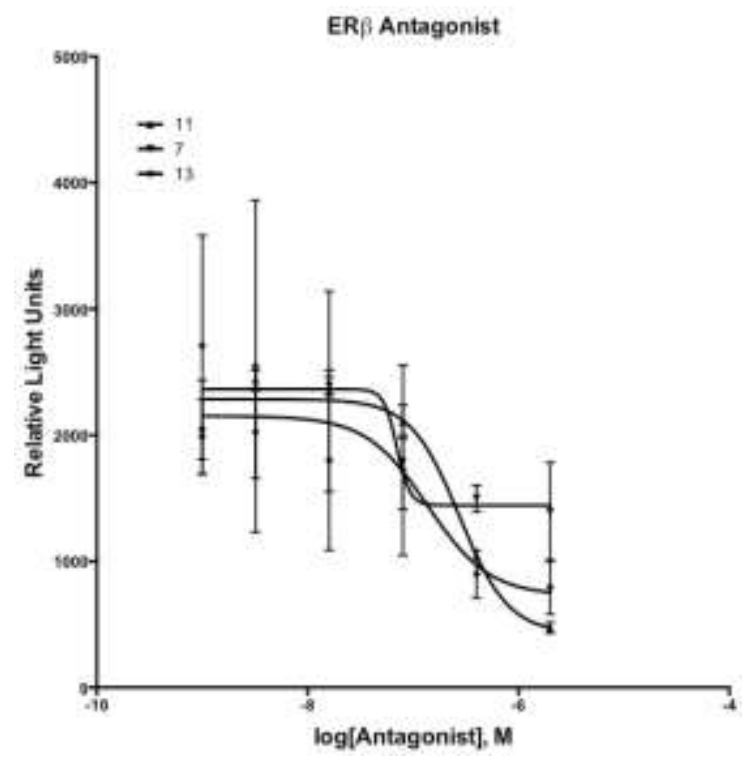

Supplementary Figure S5. Cell-based ER $\beta$ assay data for chemicals that showed antagonist activity.

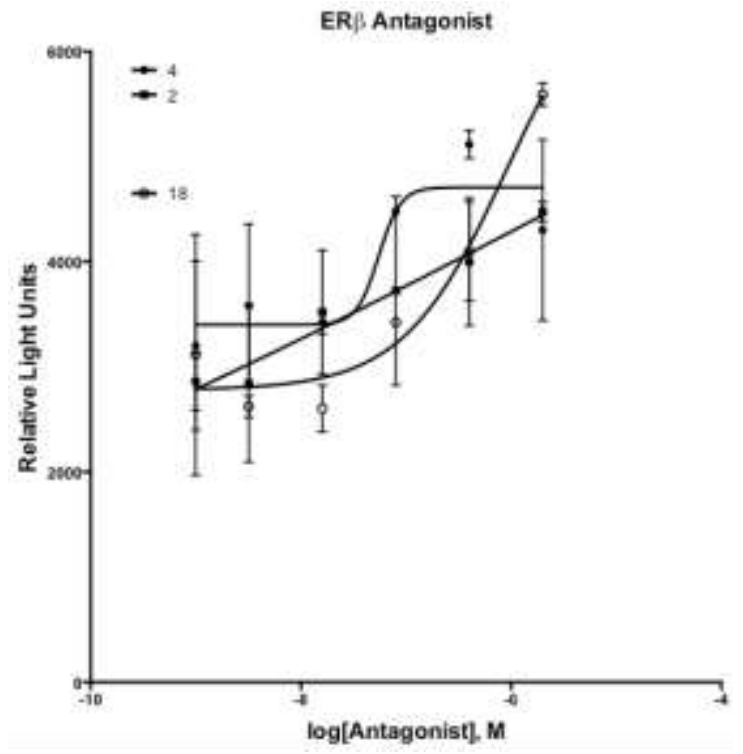

Supplementary Figure S6. Cell-based ERß assay data for chemicals that did not display antagonist activity. 
NOT THE PUBLISHED VERSION; this is the author's final, peer-reviewed manuscript. The published version may be accessed by following the link in the citation at the bottom of the page.
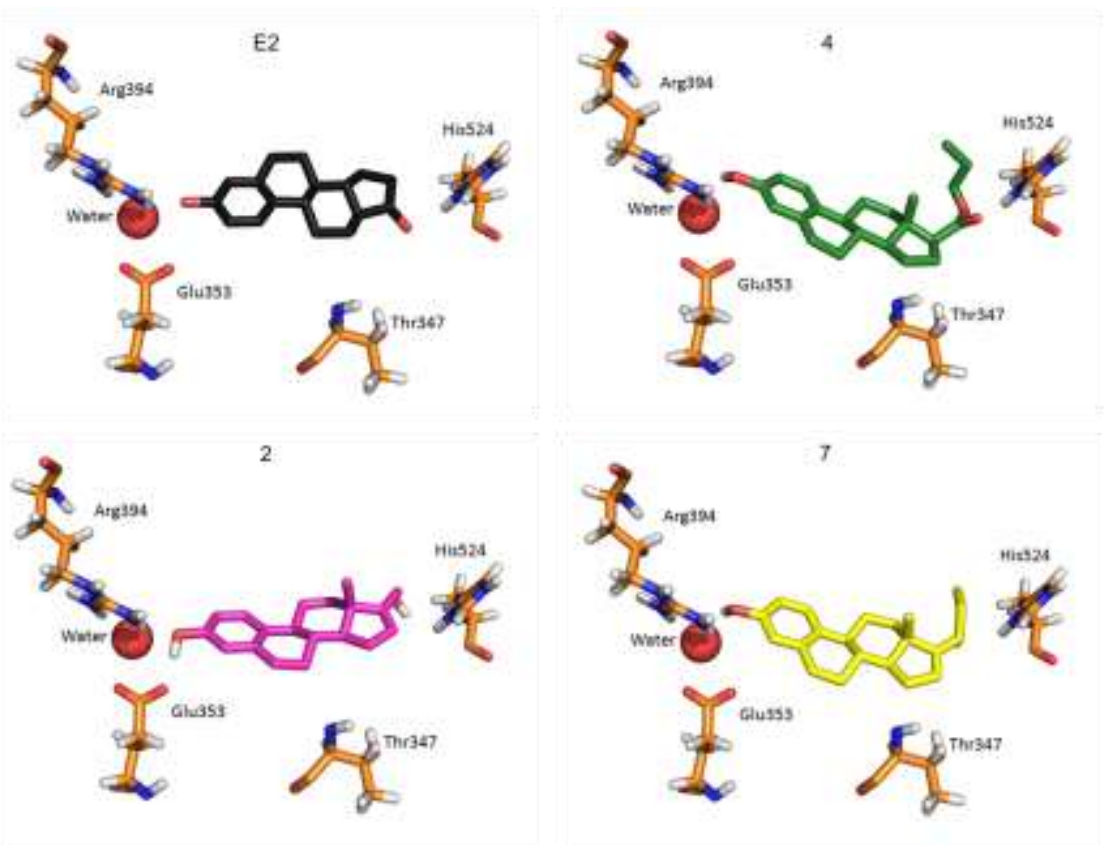

Supplementary Figure S7. Lowest energy docking poses for the ERa-binding compounds identified using fluorescence polarization. PDB file 1ere, chain A was used as the receptor to investigate the predicted affinity for binding in the ERa agonist conformation. Note: E2 is estradiol and provided for comparison.
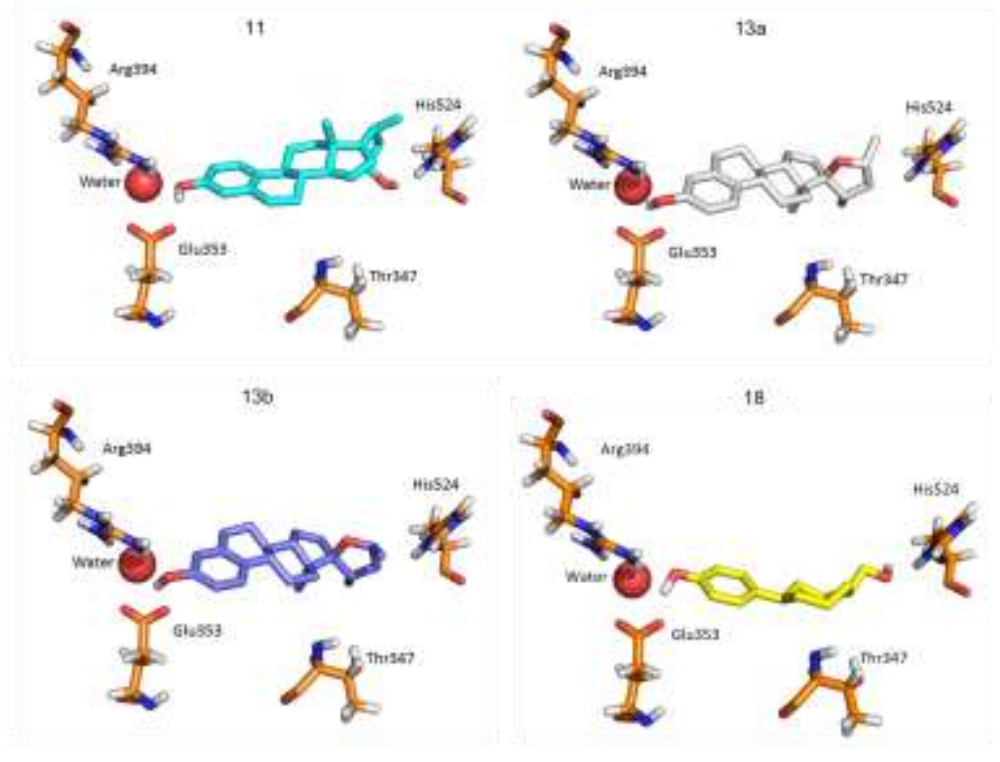

Supplementary Figure S8. Lowest energy docking poses for the ERa-binding compounds identified using fluorescence polarization. PDB file 1ere, chain A was used as the receptor to investigate the predicted affinity for binding in the ERa agonist conformation. Note: chemical 13 was docked using both enantiomers from the racemic mixture.

Bioorganic \& Medicinal Chemistry, Vol. 22, No. 1 (January 1, 2014): pg. 303-310. DOI. This article is (c Elsevier and permission has been granted for this version to appear in e-Publications@Marquette. Elsevier does not grant permission for this article to be further copied/distributed or hosted elsewhere without the express permission from Elsevier. 
NOT THE PUBLISHED VERSION; this is the author's final, peer-reviewed manuscript. The published version may be accessed by following the link in the citation at the bottom of the page.
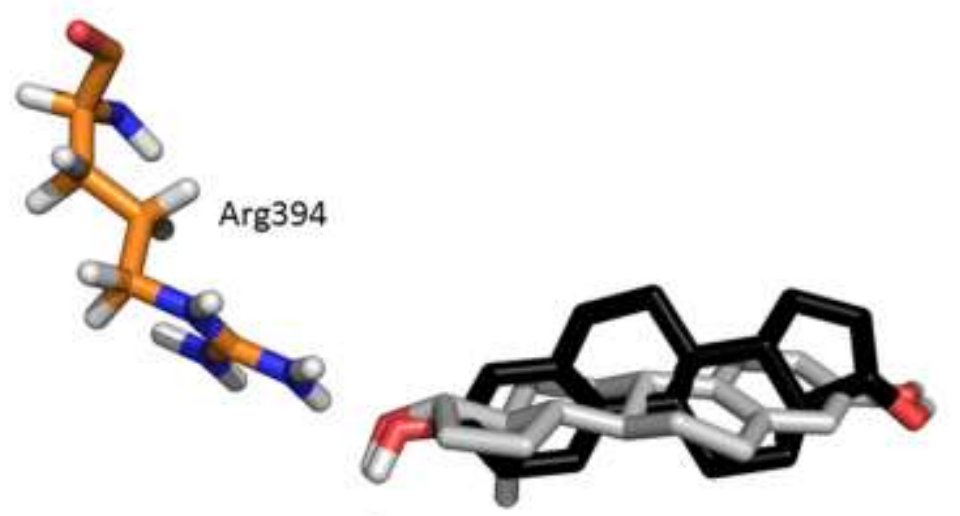

His524
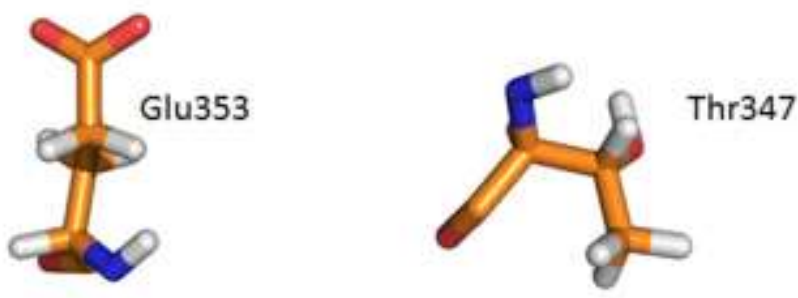

Supplementary Figure S9. Estradiol docked into PDB file 1ere, chain A with removal of all water molecules. Black is the binding mode associated with the crystal structure (normal). Gray is a $180^{\circ}$ rotation of the estradiol (reversed).

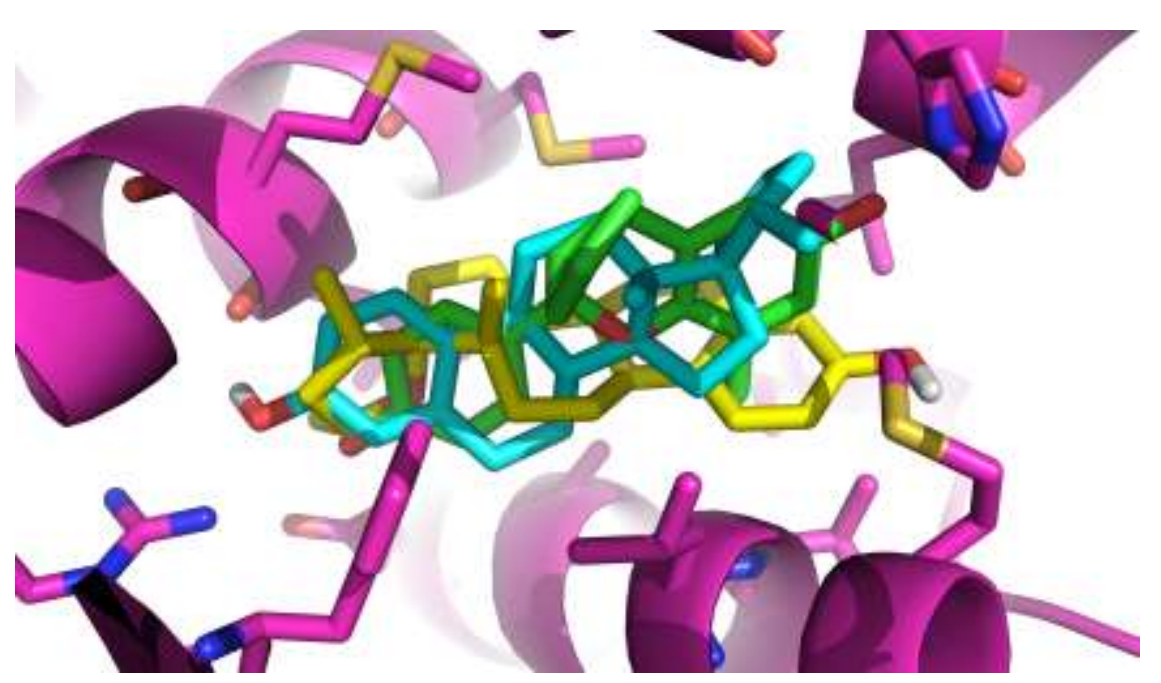

Supplementary Figure S10. ER $\beta$ agonist conformation (purple) with cocrystalized ligand (green) and docking pose predictions of $\mathbf{1 0}$ (blue) and $\mathbf{1 3}$ (yellow).

Bioorganic \& Medicinal Chemistry, Vol. 22, No. 1 (January 1, 2014): pg. 303-310. DOI. This article is @ Elsevier and permission has been granted for this version to appear in e-Publications@Marquette. Elsevier does not grant permission for this article to be further copied/distributed or hosted elsewhere without the express permission from Elsevier. 
NOT THE PUBLISHED VERSION; this is the author's final, peer-reviewed manuscript. The published version may be accessed by following the link in the citation at the bottom of the page.

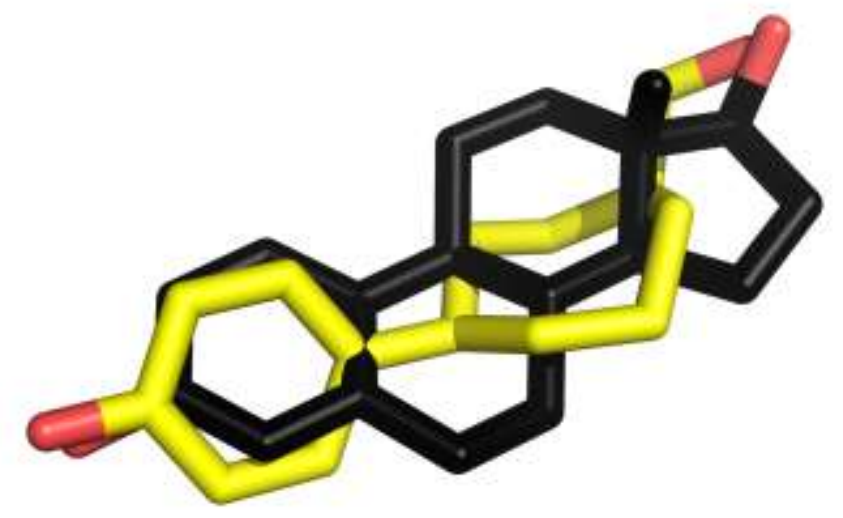

Supplementary Figure S11. Overlay of estradiol (black) and $\mathbf{1 8}$ (yellow).

Bioorganic \& Medicinal Chemistry, Vol. 22, No. 1 (January 1, 2014): pg. 303-310. DOI. This article is (C) Elsevier and permission has been granted for this version to appear in e-Publications@Marquette. Elsevier does not grant permission for this article to be further copied/distributed or hosted elsewhere without the express permission from Elsevier. 
NOT THE PUBLISHED VERSION; this is the author's final, peer-reviewed manuscript. The published version may be accessed by following the link in the citation at the bottom of the page.

Supplementary Table S1. Docking results for the agonist conformation of ER $\alpha$ in the absence of all water molecules.

\begin{tabular}{|c|c|c|c|c|}
\hline Compound & 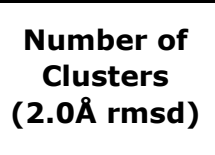 & $\begin{array}{c}\text { Lowest } \\
\text { Energy } \\
\text { Cluster } \\
\text { Population }\end{array}$ & $\begin{array}{c}\text { Calculated } \\
\text { Binding } \\
\text { Energy }\left(\mathrm{kcal}^{-}\right. \\
\left.\mathrm{mol}^{-1}\right)\end{array}$ & Mode \\
\hline estradiol & 2 & 69 & -10.74 & reversed \\
\hline estradiol & & 31 & -10.72 & normal \\
\hline 4 & 2 & 64 & -11.09 & reversed \\
\hline 4 & & 36 & -10.71 & normal \\
\hline 2 & 1 & 100 & -10.98 & reversed \\
\hline 7 & 2 & 56 & -9.93 & reversed \\
\hline 7 & & 44 & -9.79 & normal \\
\hline 11 & 3 & 69 & -10.35 & reversed \\
\hline 11 & & 29 & -9.28 & normal \\
\hline 11 & & 2 & -9.16 & reversed \\
\hline 10 & 2 & 96 & -9.48 & reversed \\
\hline 10 & & 4 & -9.08 & normal \\
\hline $13 a$ & 1 & 100 & -7.44 & normal \\
\hline $13 b$ & 1 & 100 & -9.13 & reversed \\
\hline 17 & 3 & 22 & -7.27 & reversed \\
\hline 17 & & 76 & -7.21 & reversed \\
\hline 17 & & 2 & -7.12 & normal \\
\hline 20 & 1 & 100 & -7.57 & reversed \\
\hline 18 & 2 & 85 & -7.42 & reversed \\
\hline 18 & & 15 & -7.34 & normal \\
\hline 14 & 2 & 97 & -6.71 & normal \\
\hline 14 & & 3 & -6.39 & reversed \\
\hline 15 & 2 & 73 & -6.85 & normal \\
\hline 15 & & 27 & -6.77 & reversed \\
\hline 16 & 3 & 71 & -7.42 & reversed \\
\hline 16 & & 28 & -7.33 & normal \\
\hline 16 & & 1 & -7.17 & normal \\
\hline
\end{tabular}

Bioorganic \& Medicinal Chemistry, Vol. 22, No. 1 (January 1, 2014): pg. 303-310. DOI. This article is (C Elsevier and permission has been granted for this version to appear in e-Publications@Marquette. Elsevier does not grant permission for this article to be further copied/distributed or hosted elsewhere without the express permission from Elsevier. 
NOT THE PUBLISHED VERSION; this is the author's final, peer-reviewed manuscript. The published version may be accessed by following the link in the citation at the bottom of the page.

Supplementary Table S2. Docking results for the agonist conformation of ER $\alpha$ in the presence of a single water molecule near Arg294 and Glu353 as observed in the crystal structure. Chemicals 20 and 14 were not predicted to bind similarly to the normal or reversed modes as otherwise noted.

\begin{tabular}{|c|c|c|c|c|}
\hline Compound & $\begin{array}{l}\text { Number of } \\
\text { Clusters } \\
(2.0 \AA \text { rmsd })\end{array}$ & $\begin{array}{l}\text { Lowest } \\
\text { Energy } \\
\text { Cluster } \\
\text { Population }\end{array}$ & $\begin{array}{l}\text { Calculated } \\
\text { Binding } \\
\text { Energy } \\
(\text { kcal mol- } \\
1 \text { ) }\end{array}$ & Mode \\
\hline estradiol & 1 & 100 & -10.36 & normal \\
\hline 4 & 2 & 97 & -10.29 & normal \\
\hline 2 & 2 & 42 & -10.16 & reversed \\
\hline 2 & 2 & 58 & -9.82 & normal \\
\hline 11 & 1 & 100 & -9.80 & normal \\
\hline 7 & 1 & 100 & -9.74 & normal \\
\hline 10 & 1 & 100 & -8.82 & normal \\
\hline $13 b$ & 1 & 100 & -8.73 & normal \\
\hline $13 a$ & 1 & 100 & -8.39 & normal \\
\hline 4 & 2 & 3 & -7.73 & reversed \\
\hline 18 & 2 & 72 & -7.56 & reversed \\
\hline 18 & 2 & 28 & -7.46 & normal \\
\hline 17 & 2 & 13 & -7.46 & reversed \\
\hline 17 & 2 & 87 & -7.37 & normal \\
\hline 16 & 2 & 97 & -7.27 & normal \\
\hline 15 & 2 & 73 & -7.00 & reversed \\
\hline 16 & 2 & 3 & -6.94 & reversed \\
\hline 20 & 4 & 76 & -6.93 & other \\
\hline 15 & 2 & 27 & -6.85 & normal \\
\hline 14 & 3 & 79 & -6.41 & other \\
\hline
\end{tabular}

Bioorganic \& Medicinal Chemistry, Vol. 22, No. 1 (January 1, 2014): pg. 303-310. DOI. This article is (c Elsevier and permission has been granted for this version to appear in e-Publications@Marquette. Elsevier does not grant permission for this article to be further copied/distributed or hosted elsewhere without the express permission from Elsevier. 
NOT THE PUBLISHED VERSION; this is the author's final, peer-reviewed manuscript. The published version may be accessed by following the link in the citation at the bottom of the page.

\section{Supplementary Material 2}

Bioorganic \& Medicinal Chemistry, Vol. 22, No. 1 (January 1, 2014): pg. 303-310. DOI. This article is (c Elsevier and permission has been granted for this version to appear in e-Publications@Marquette. Elsevier does not grant permission for this article to be further copied/distributed or hosted elsewhere without the express permission from Elsevier. 


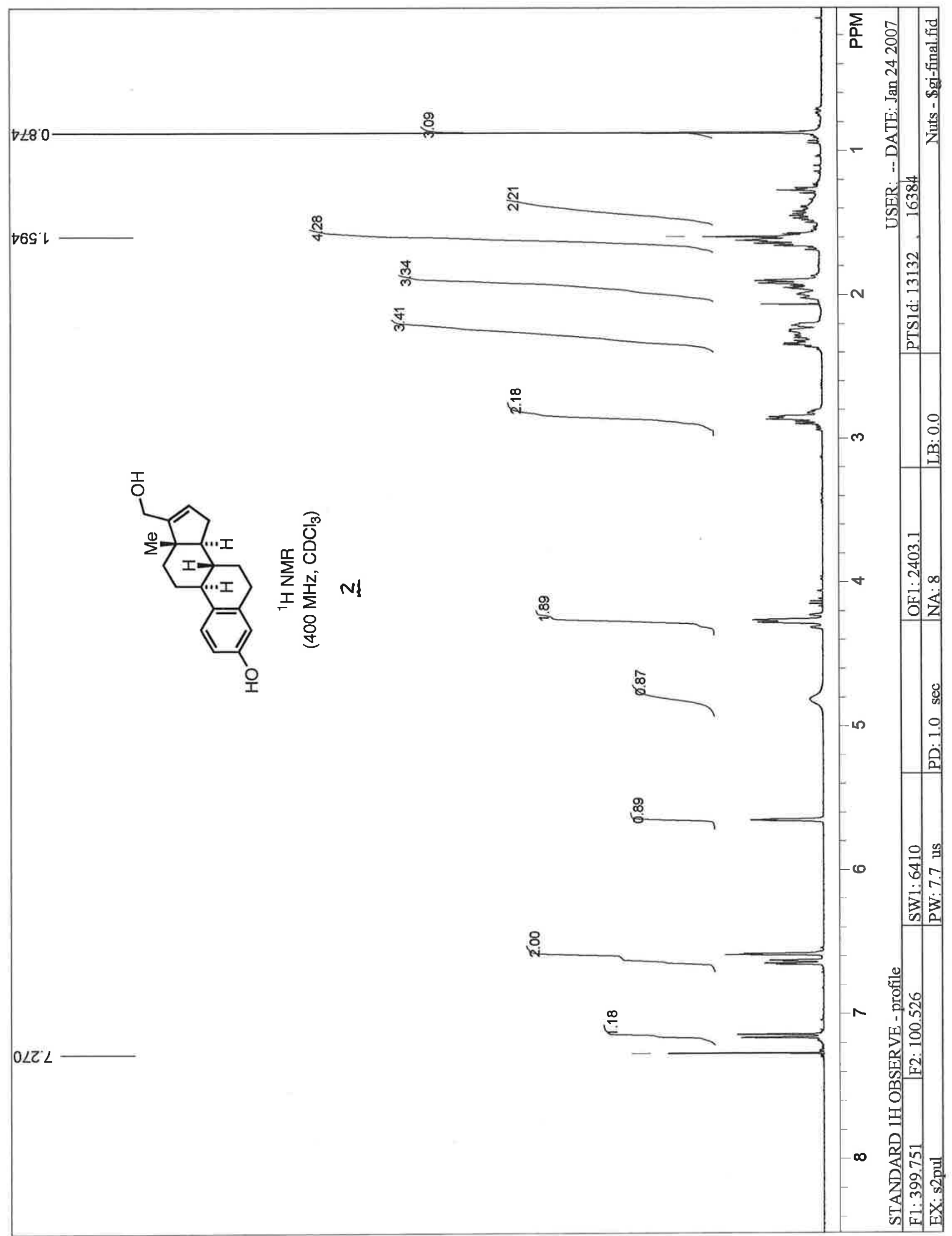




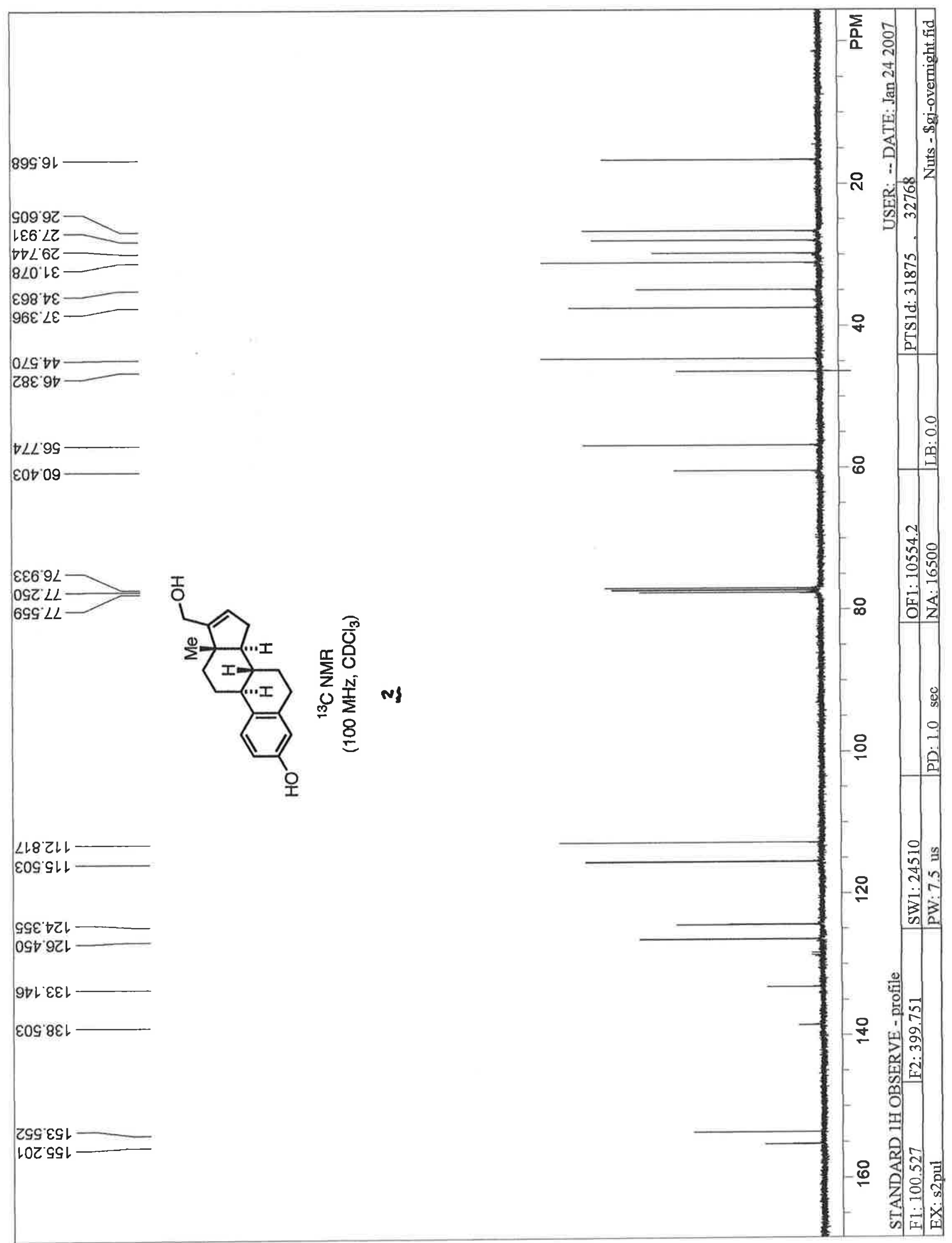




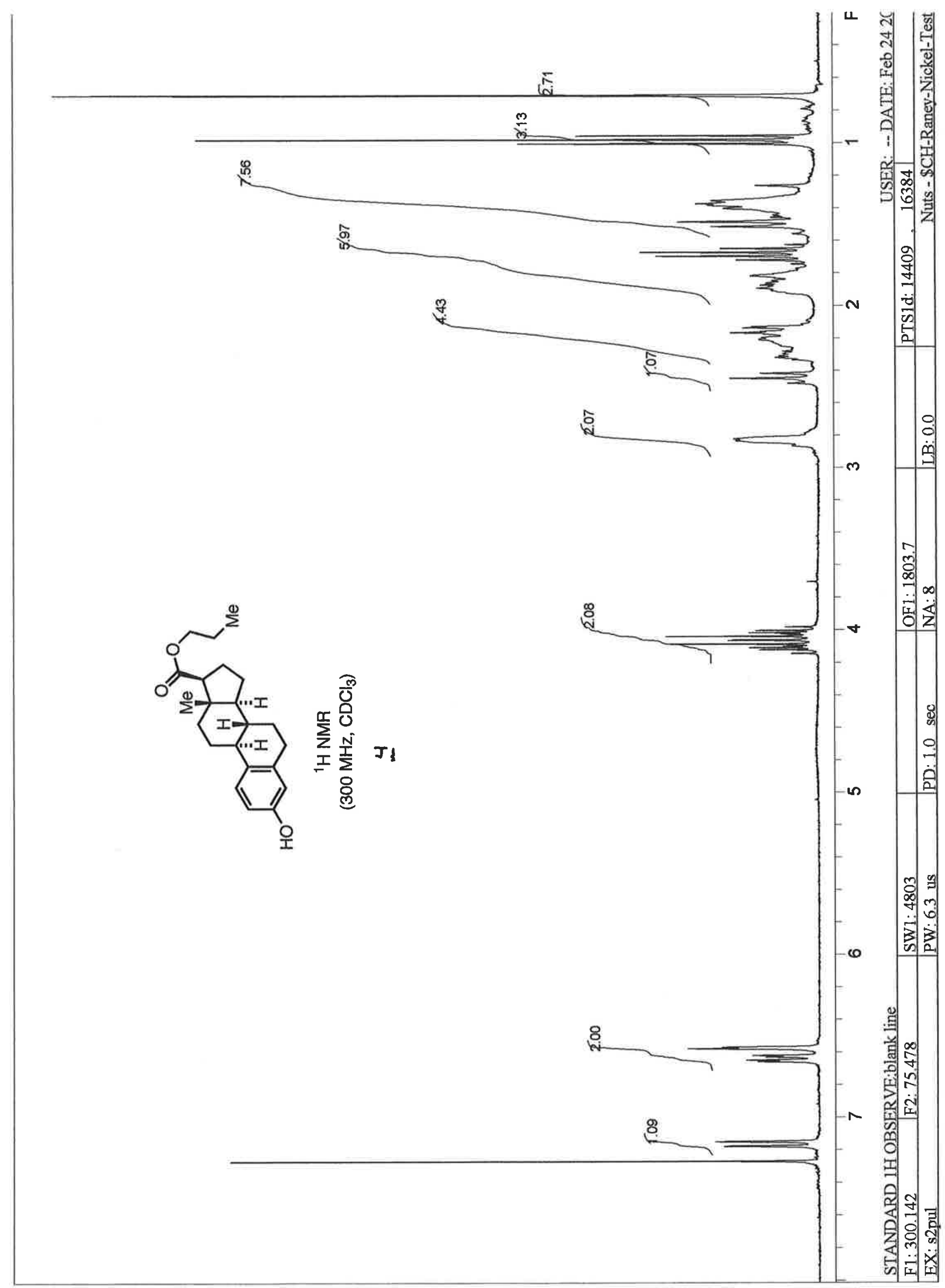




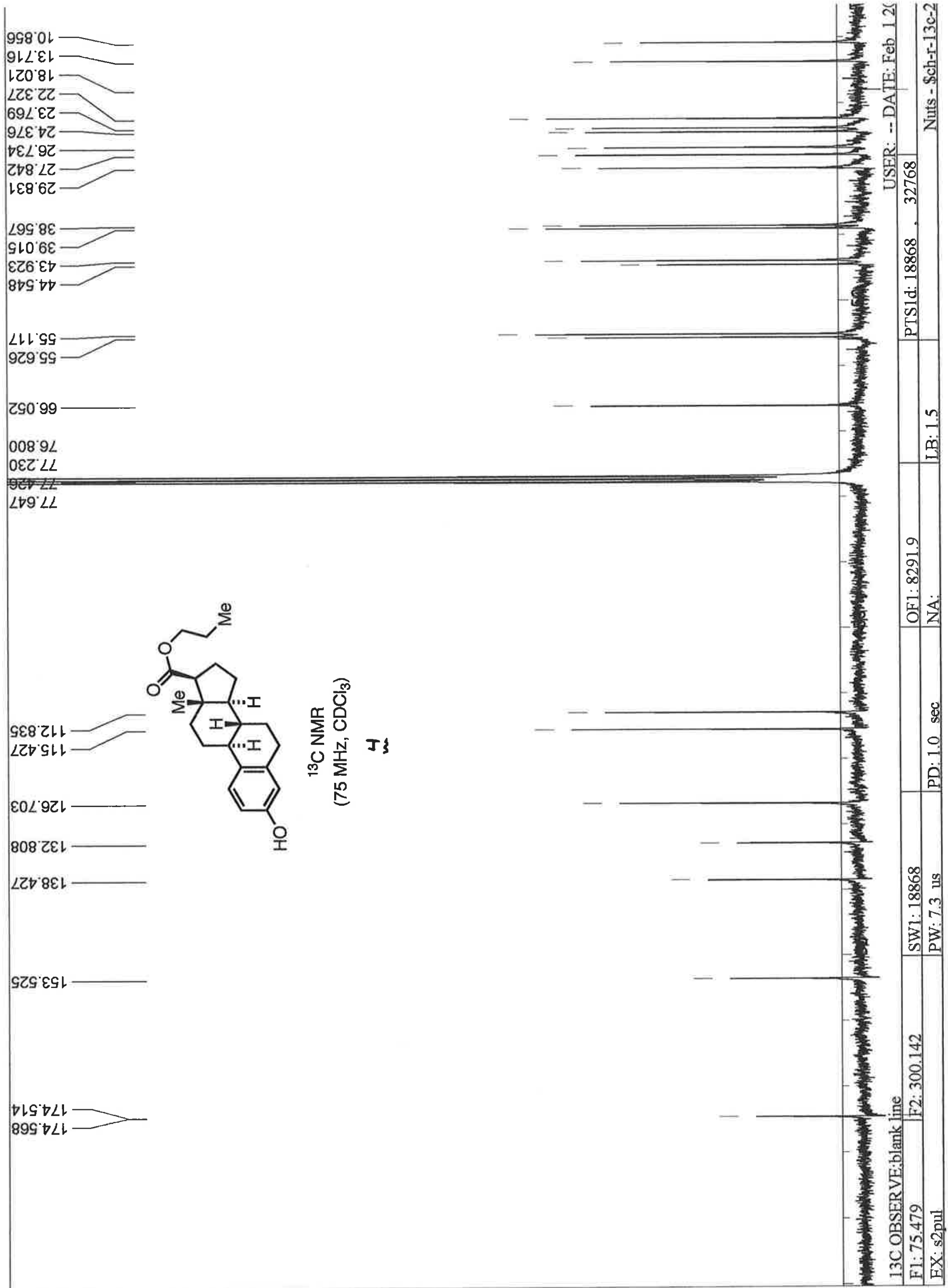




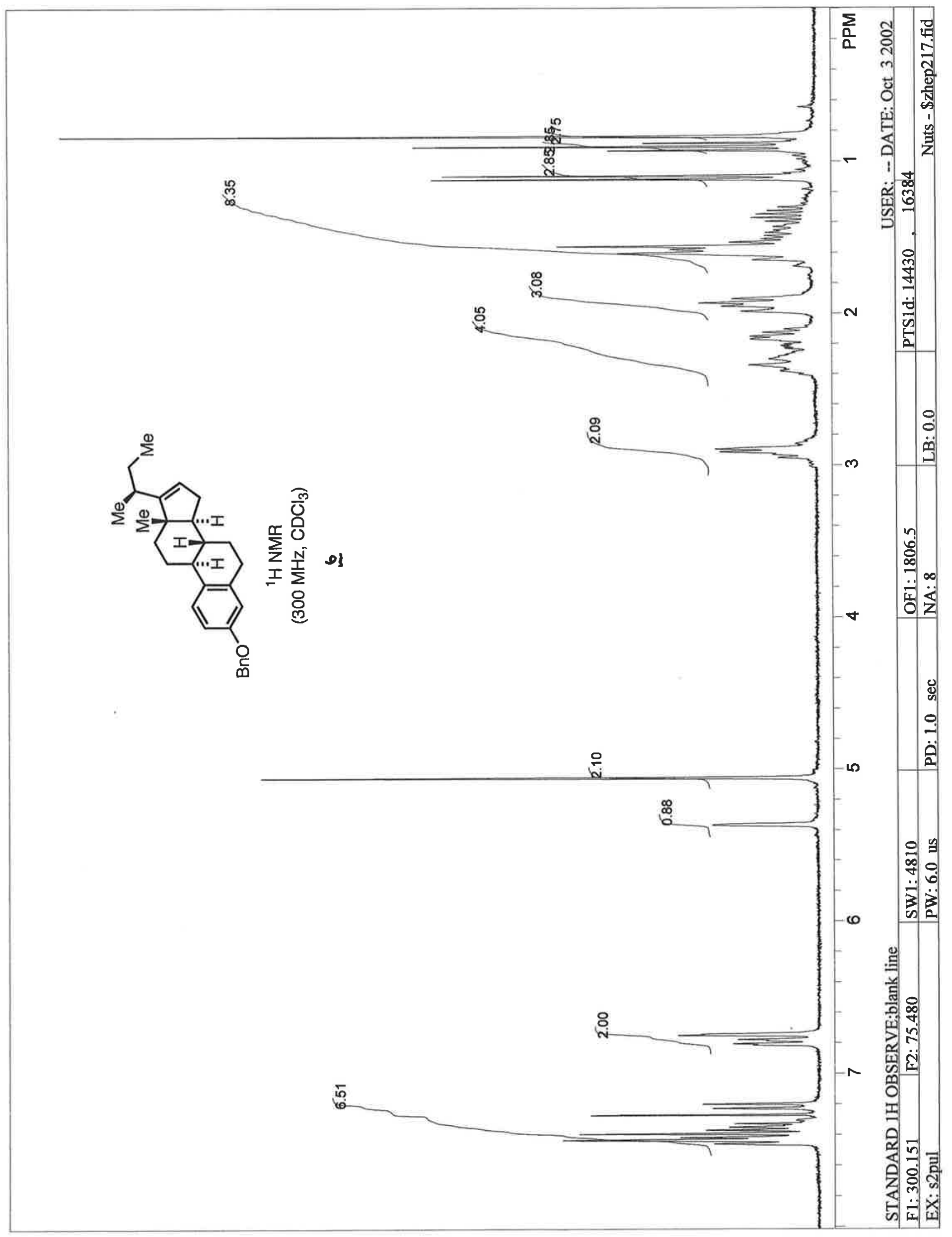




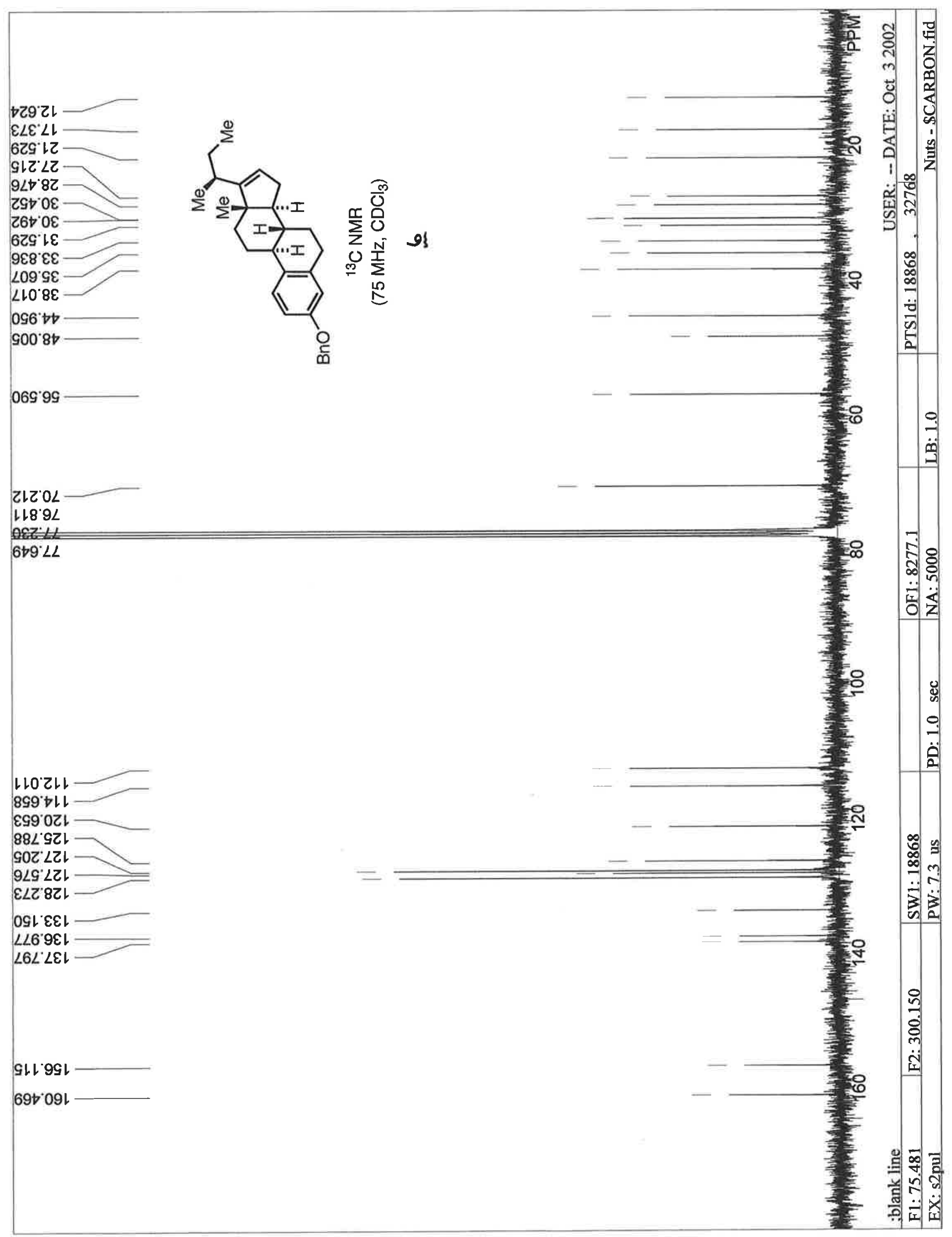




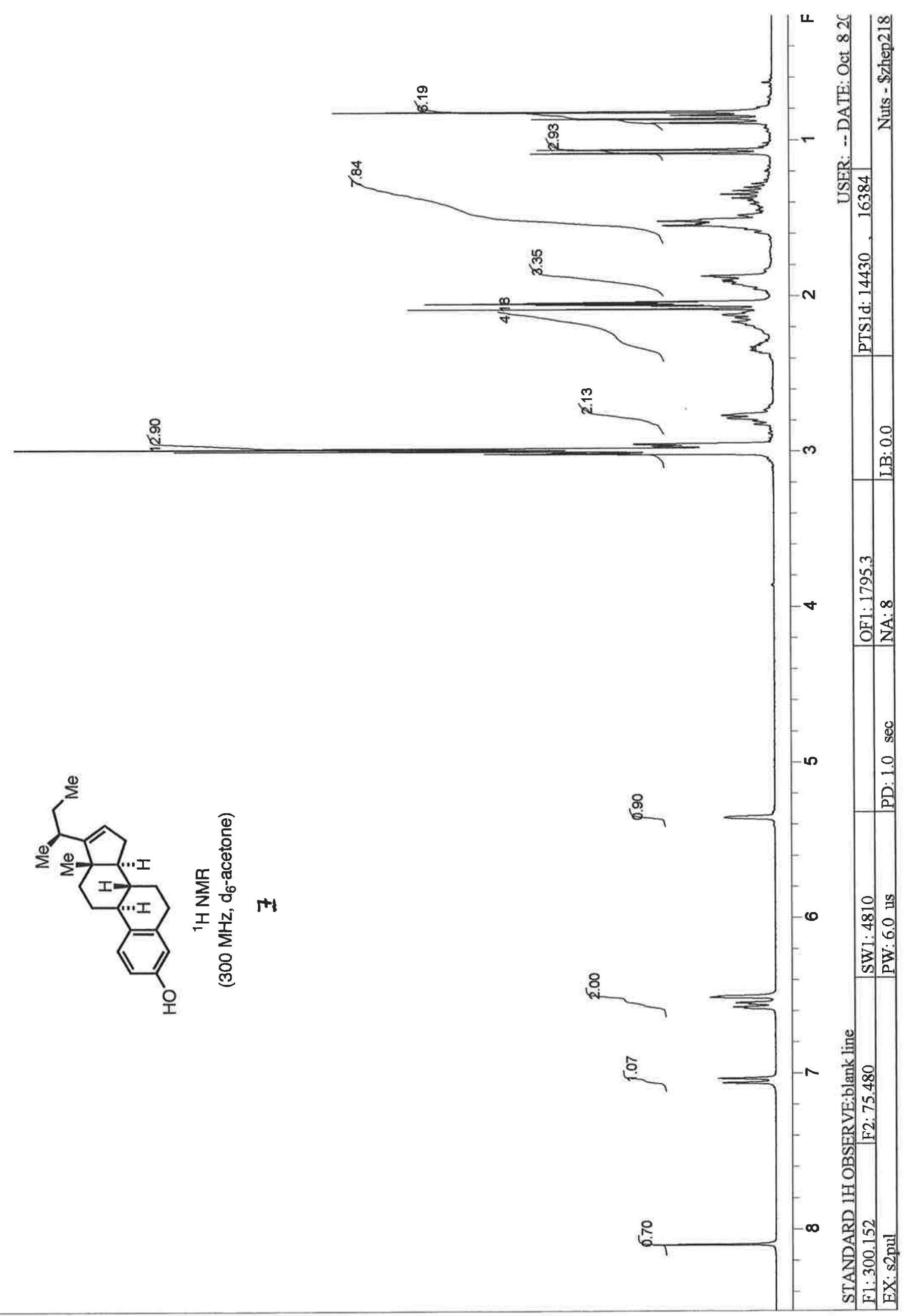




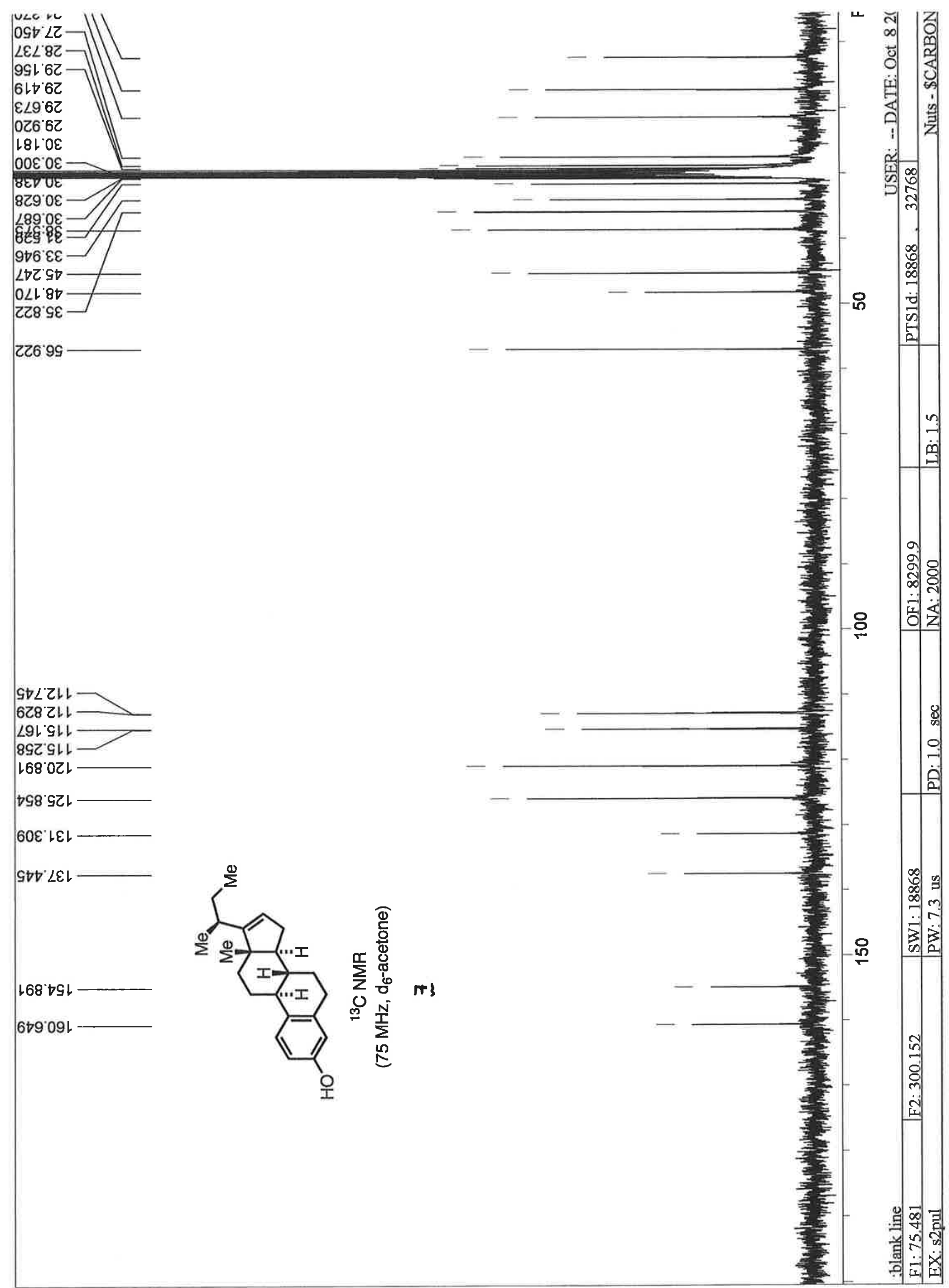




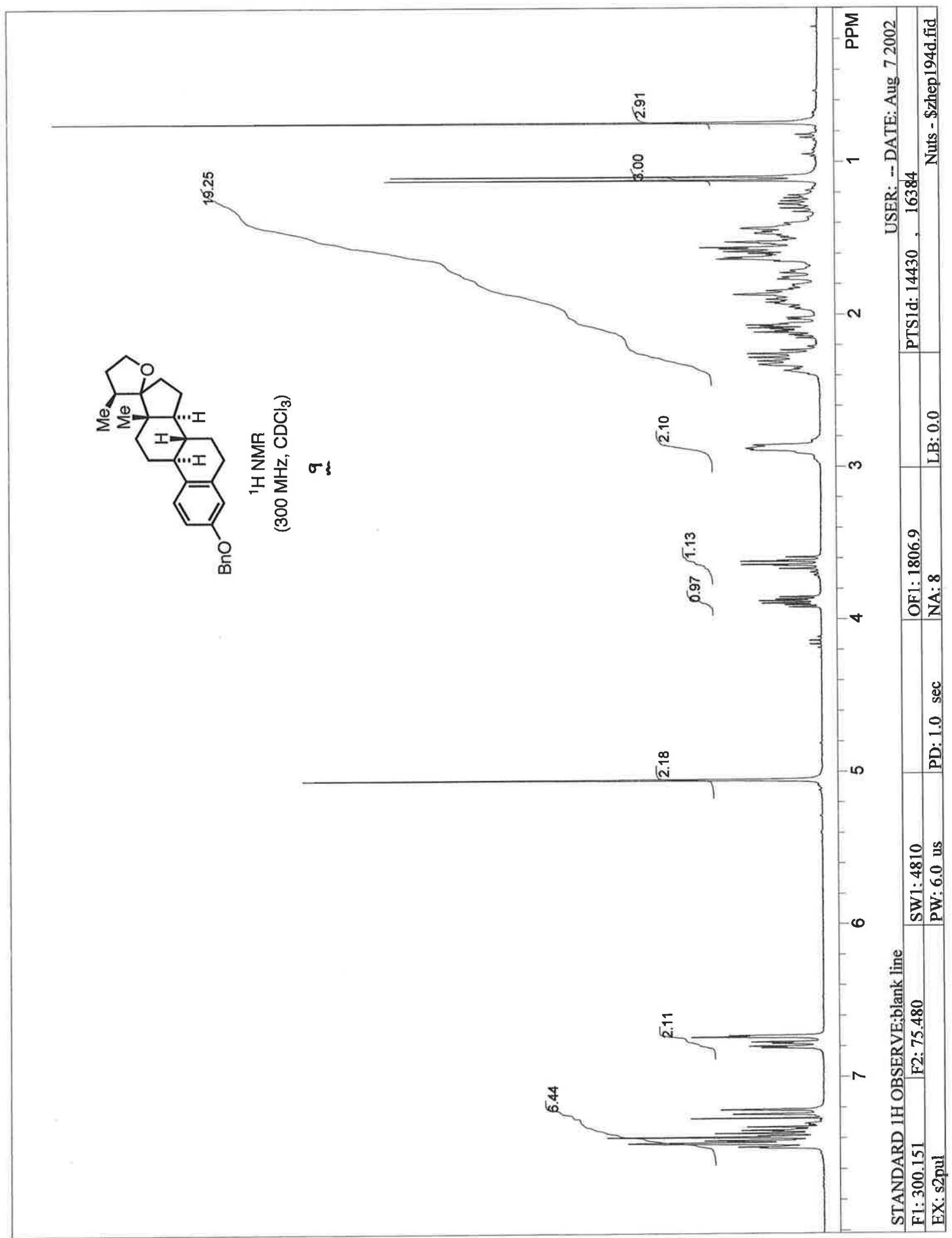




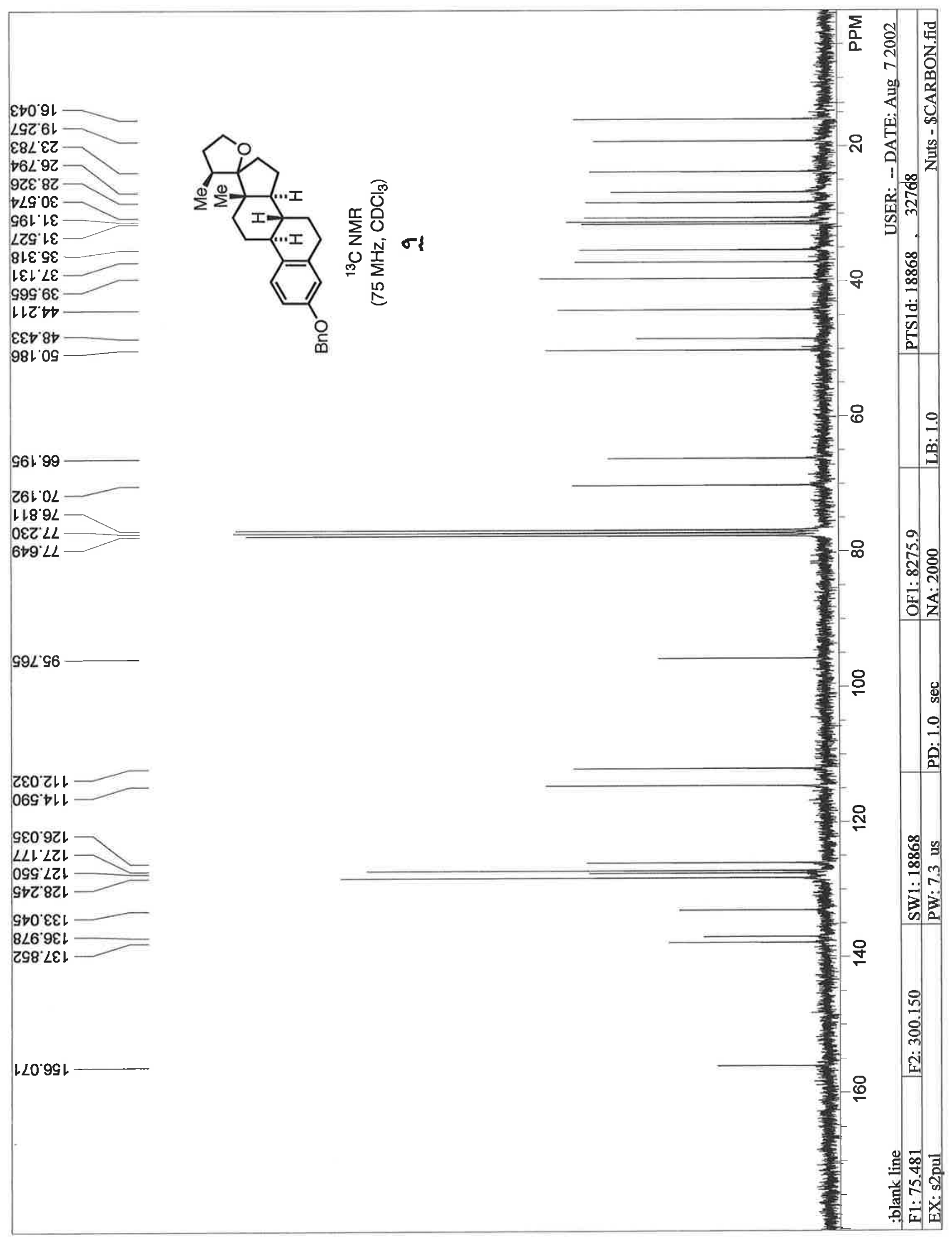




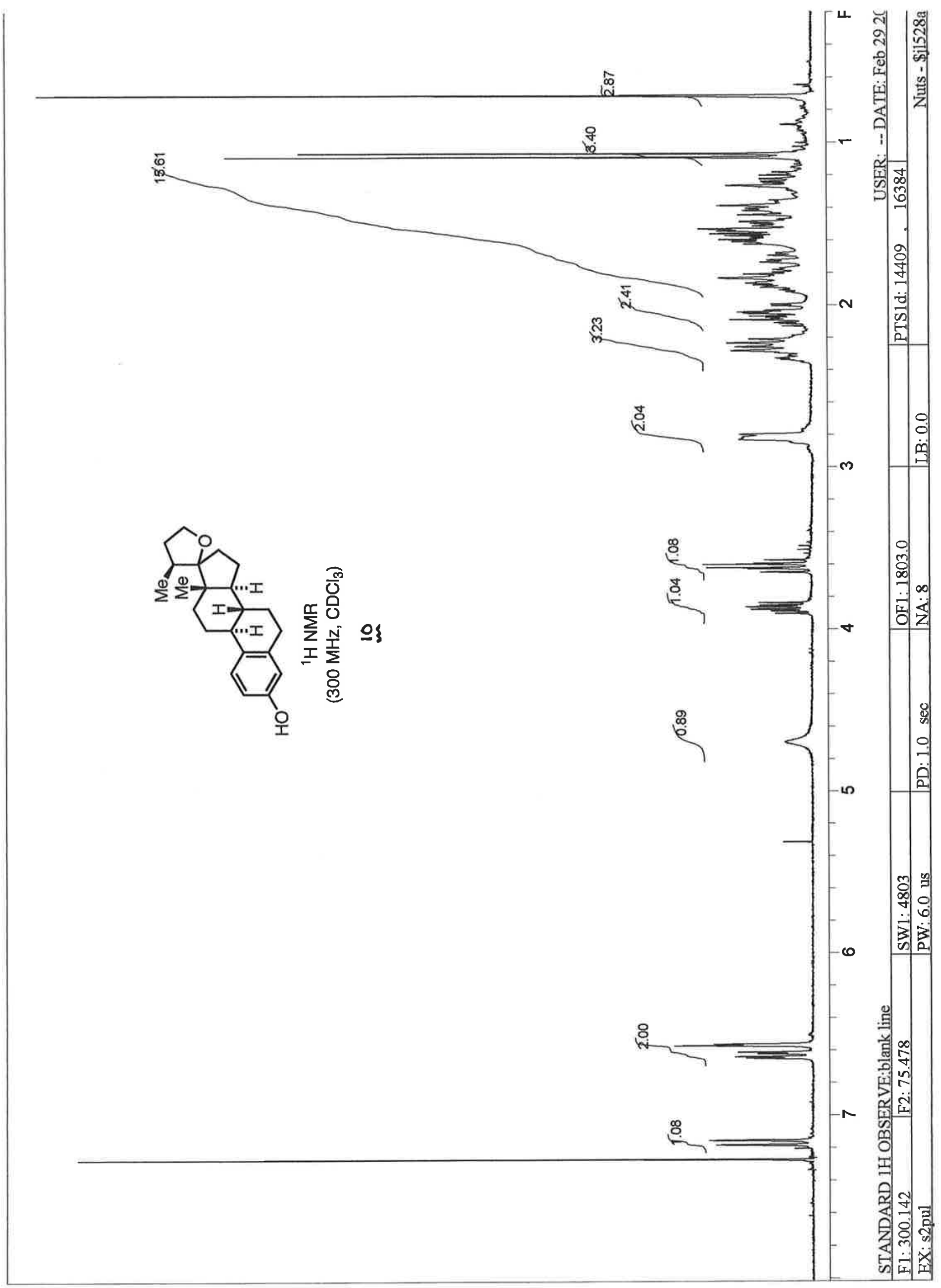




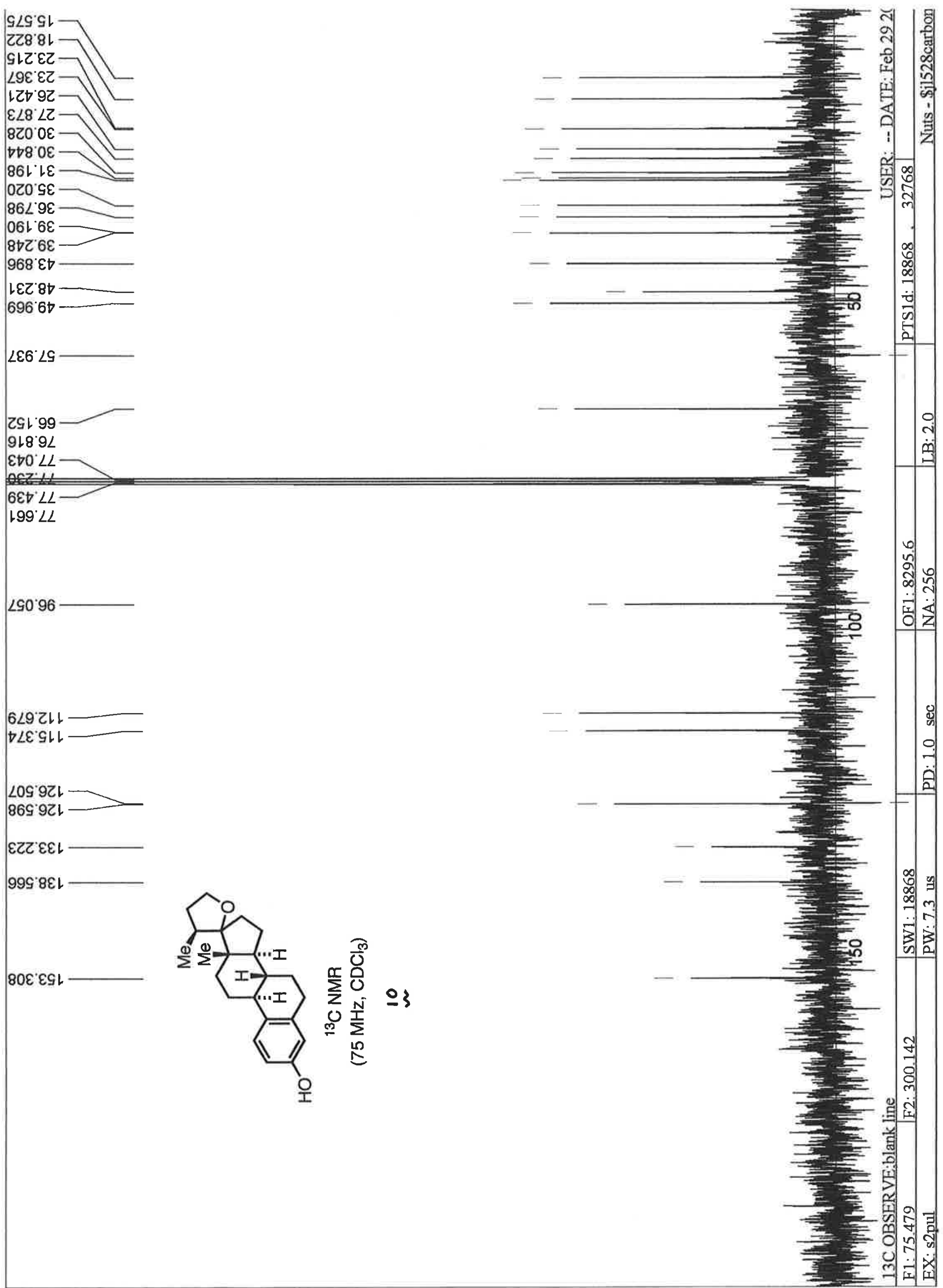




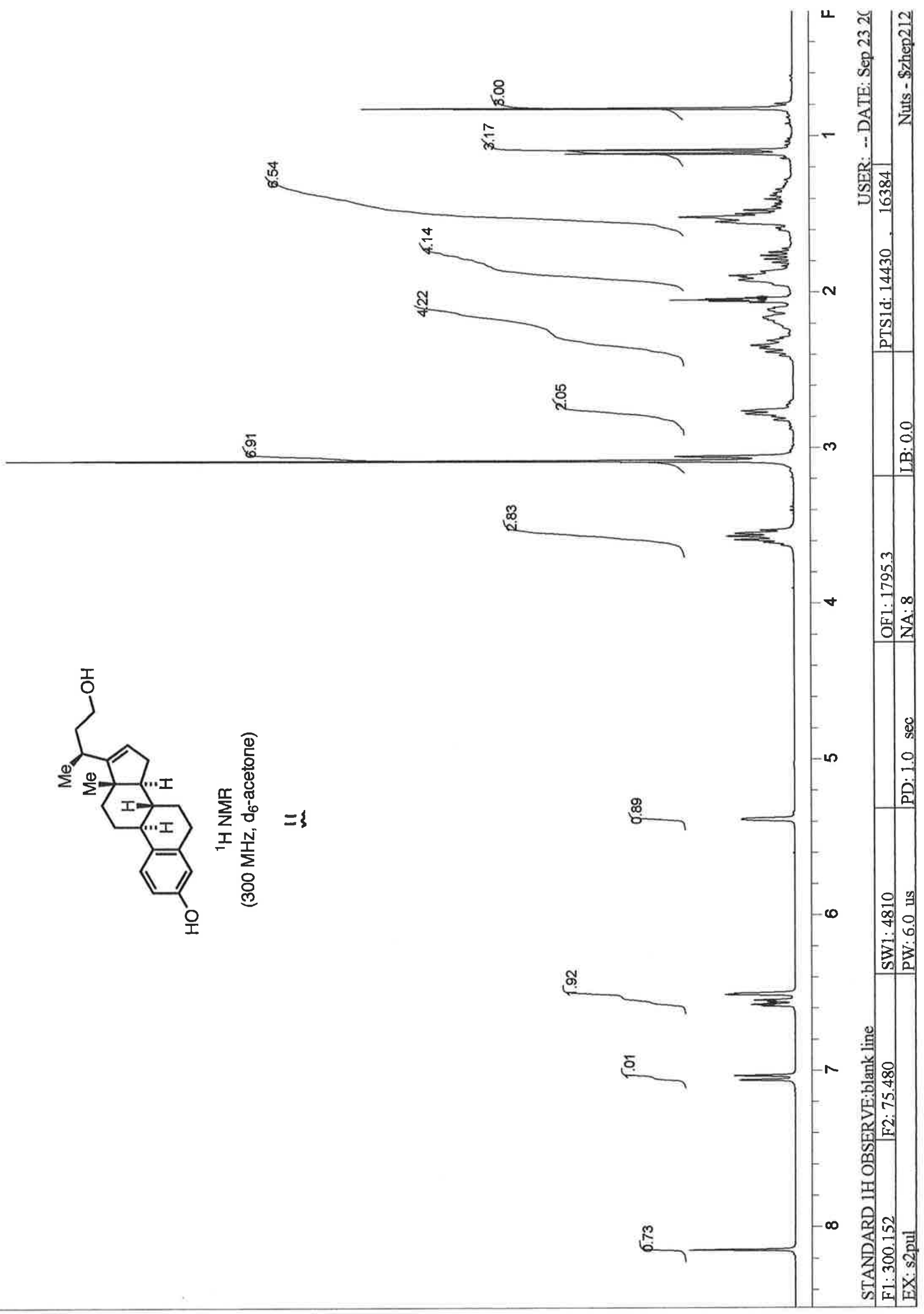




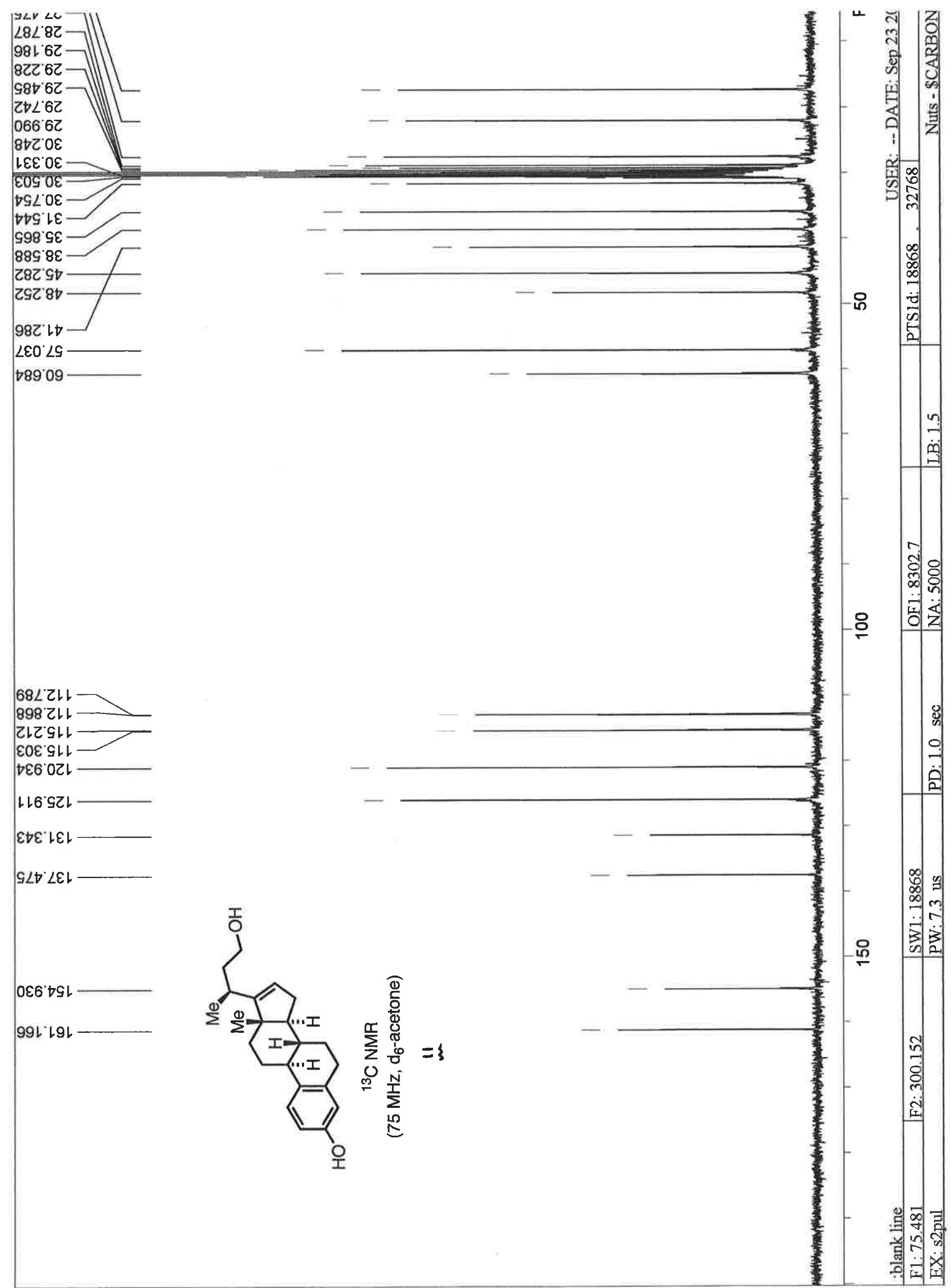




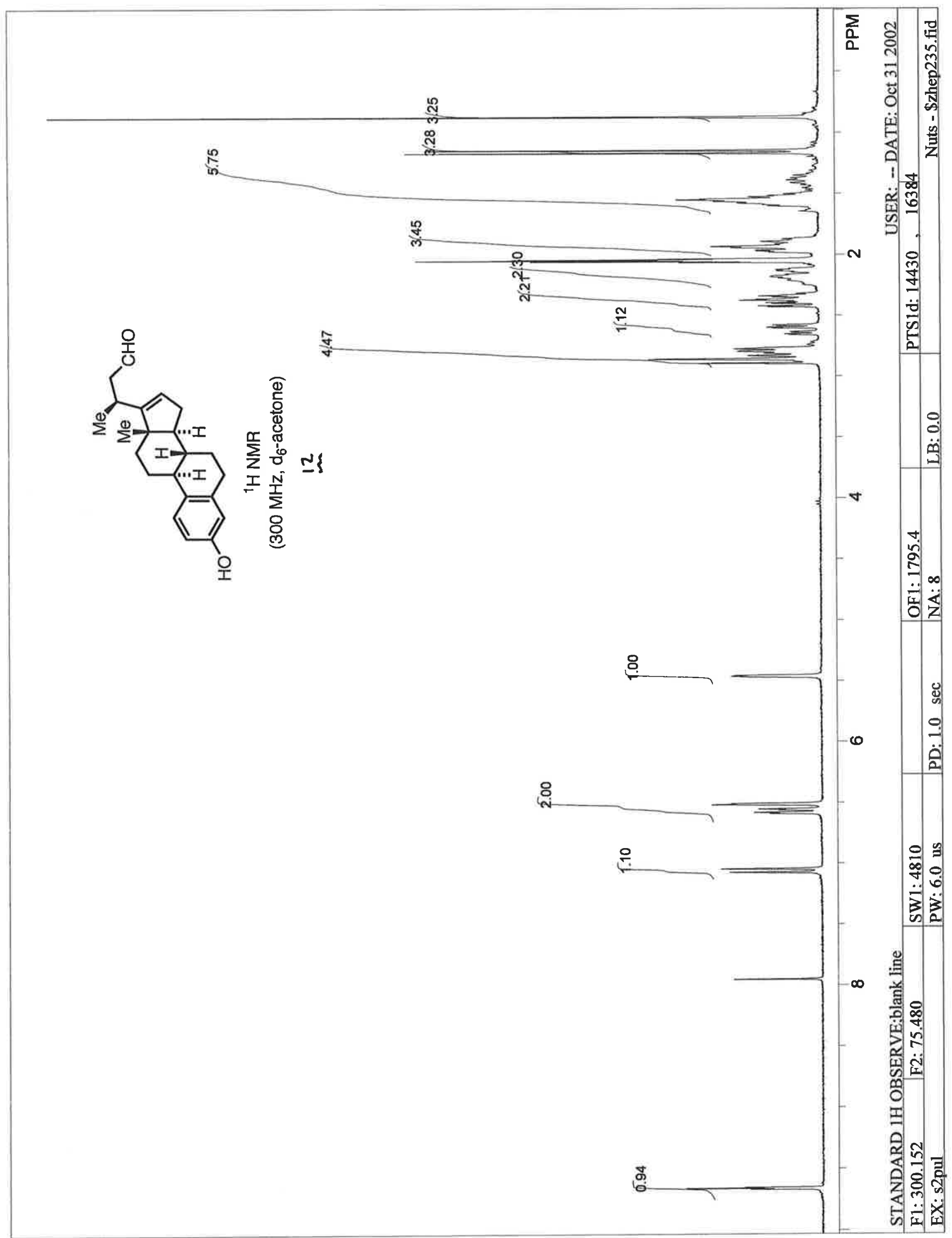




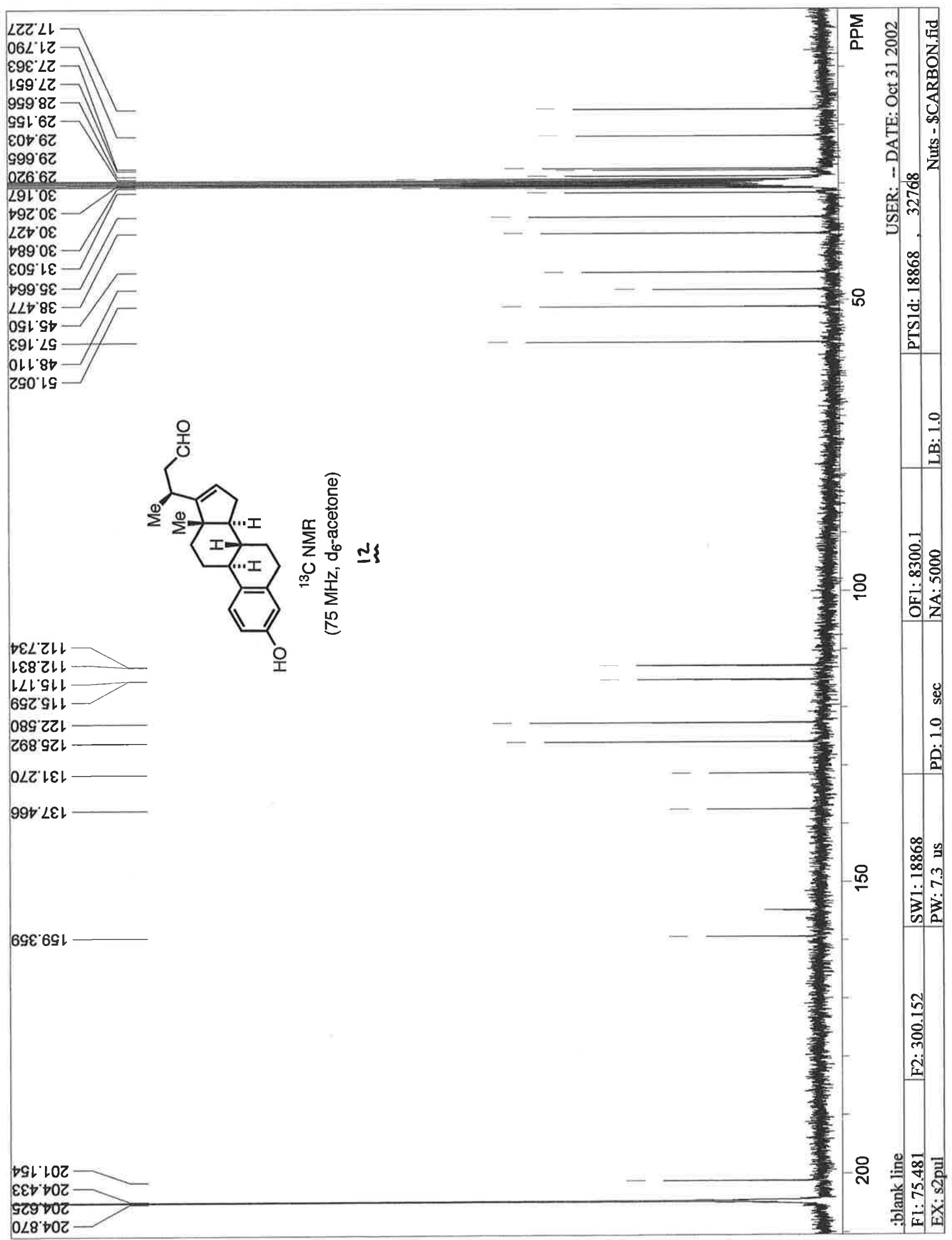




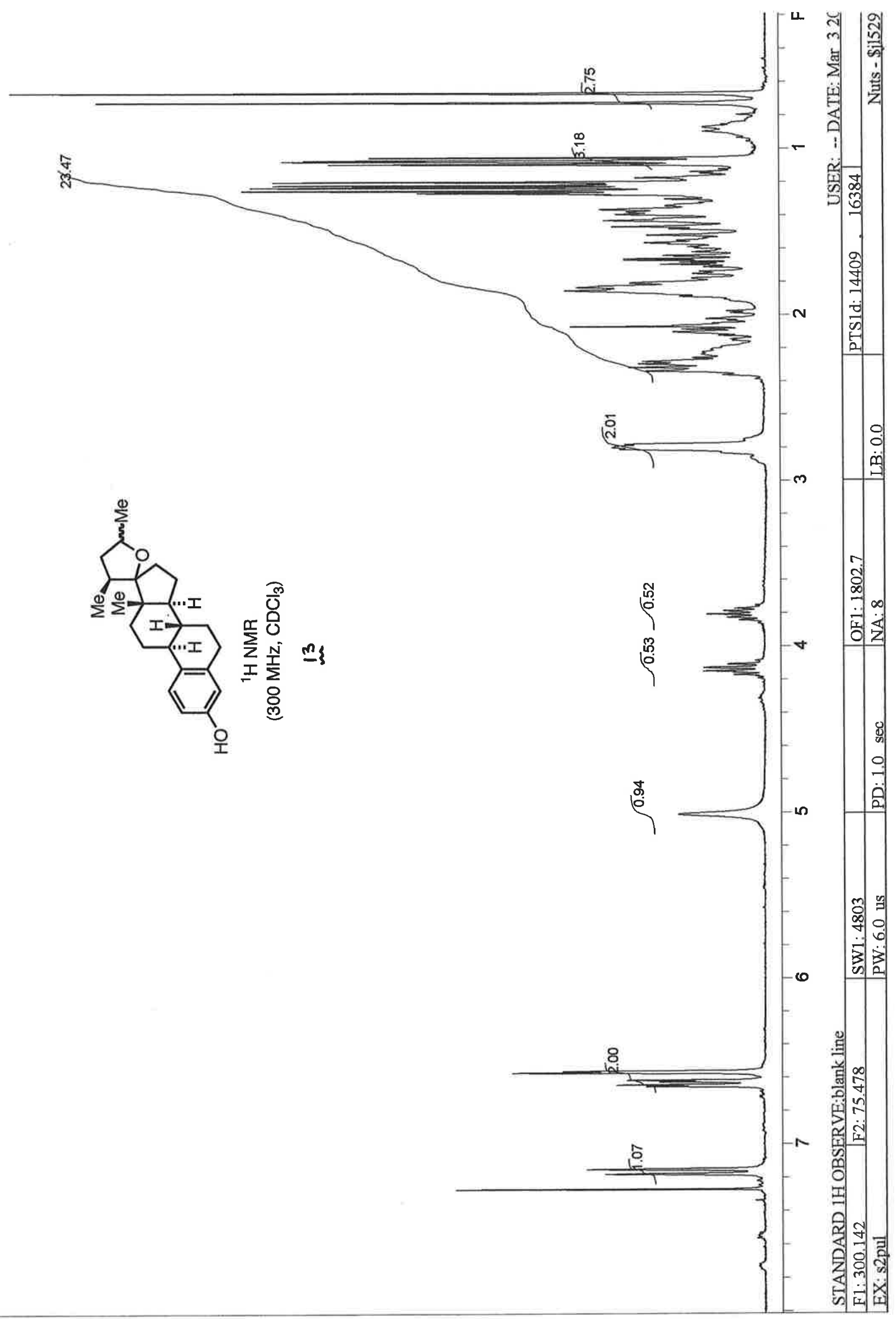




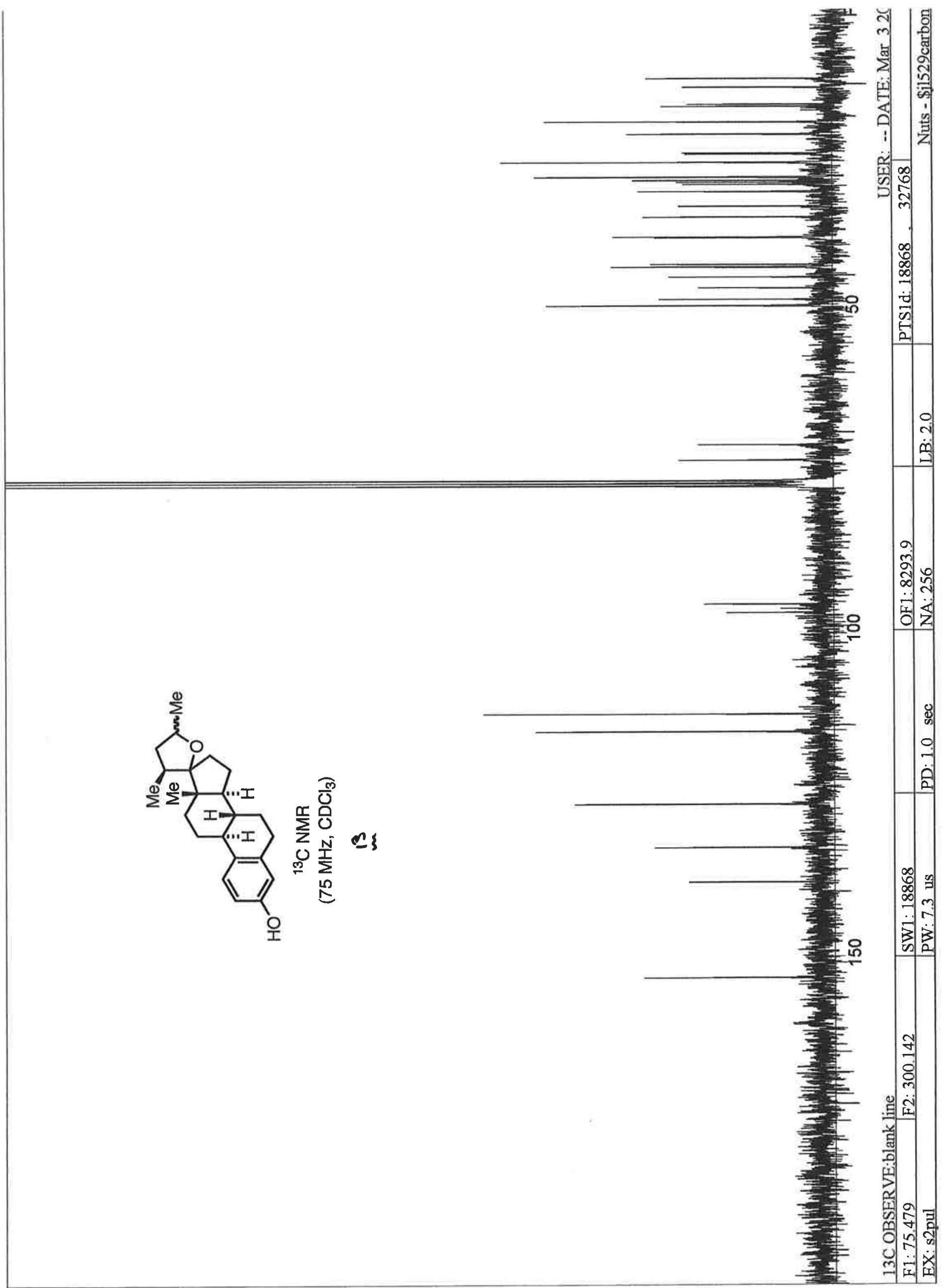




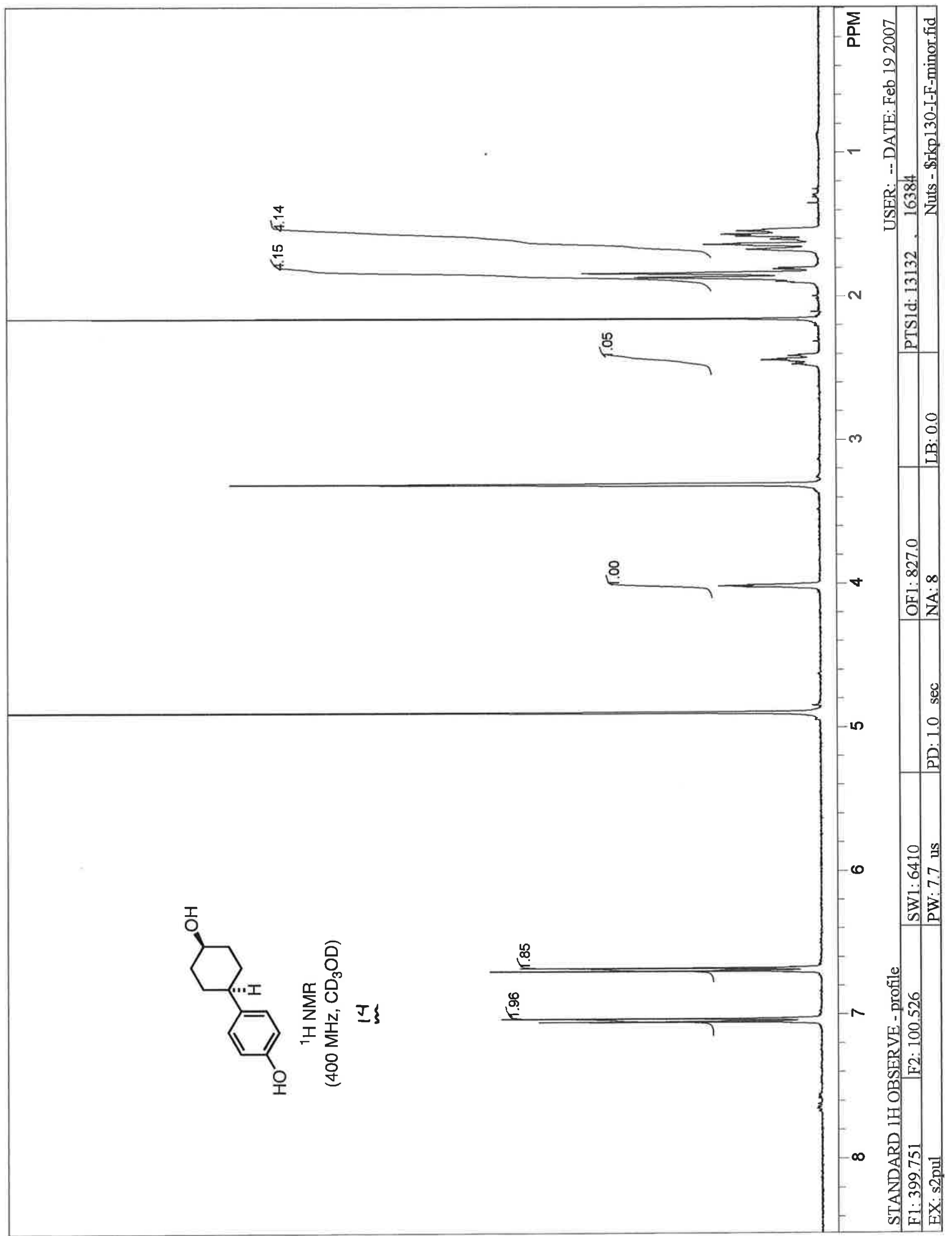




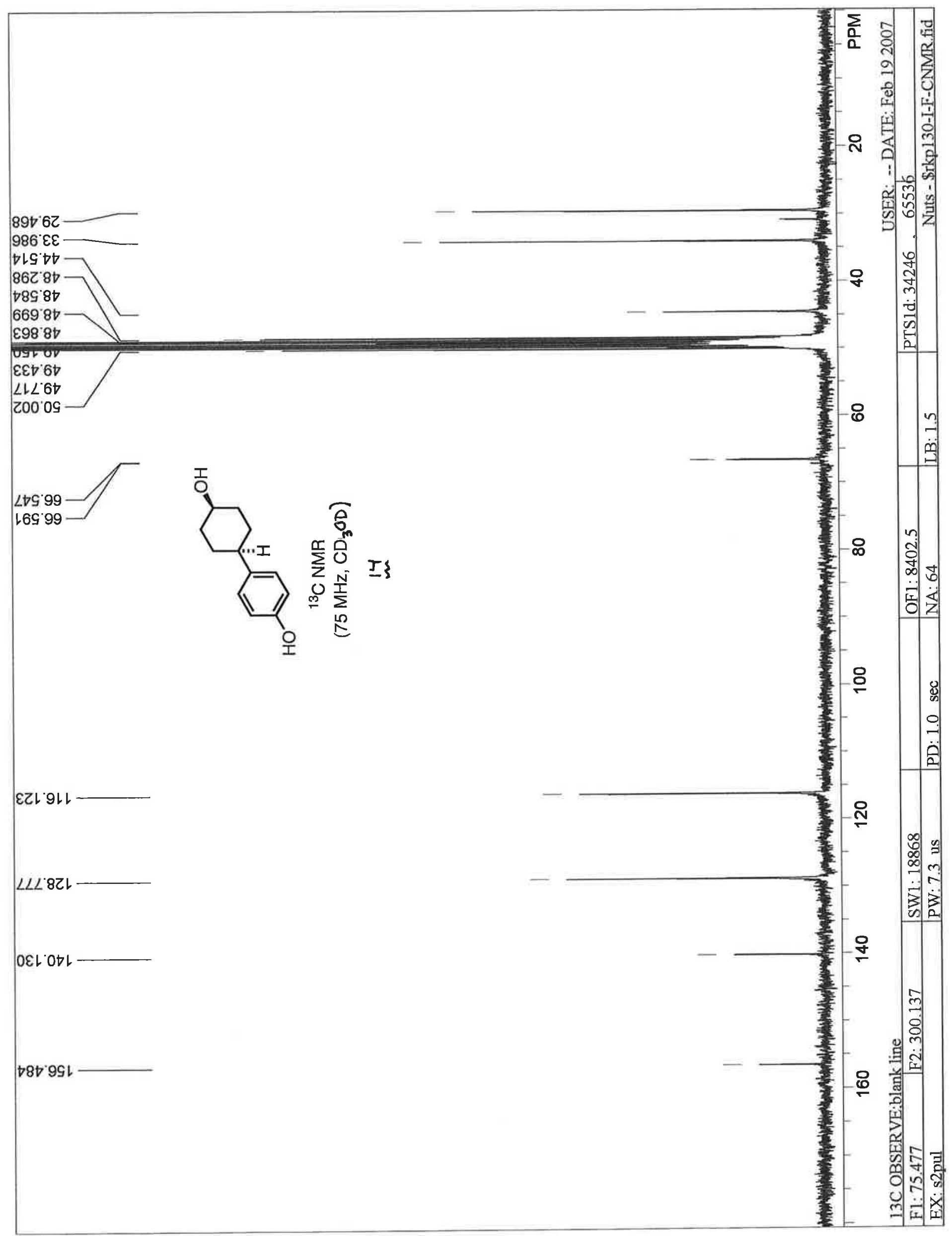




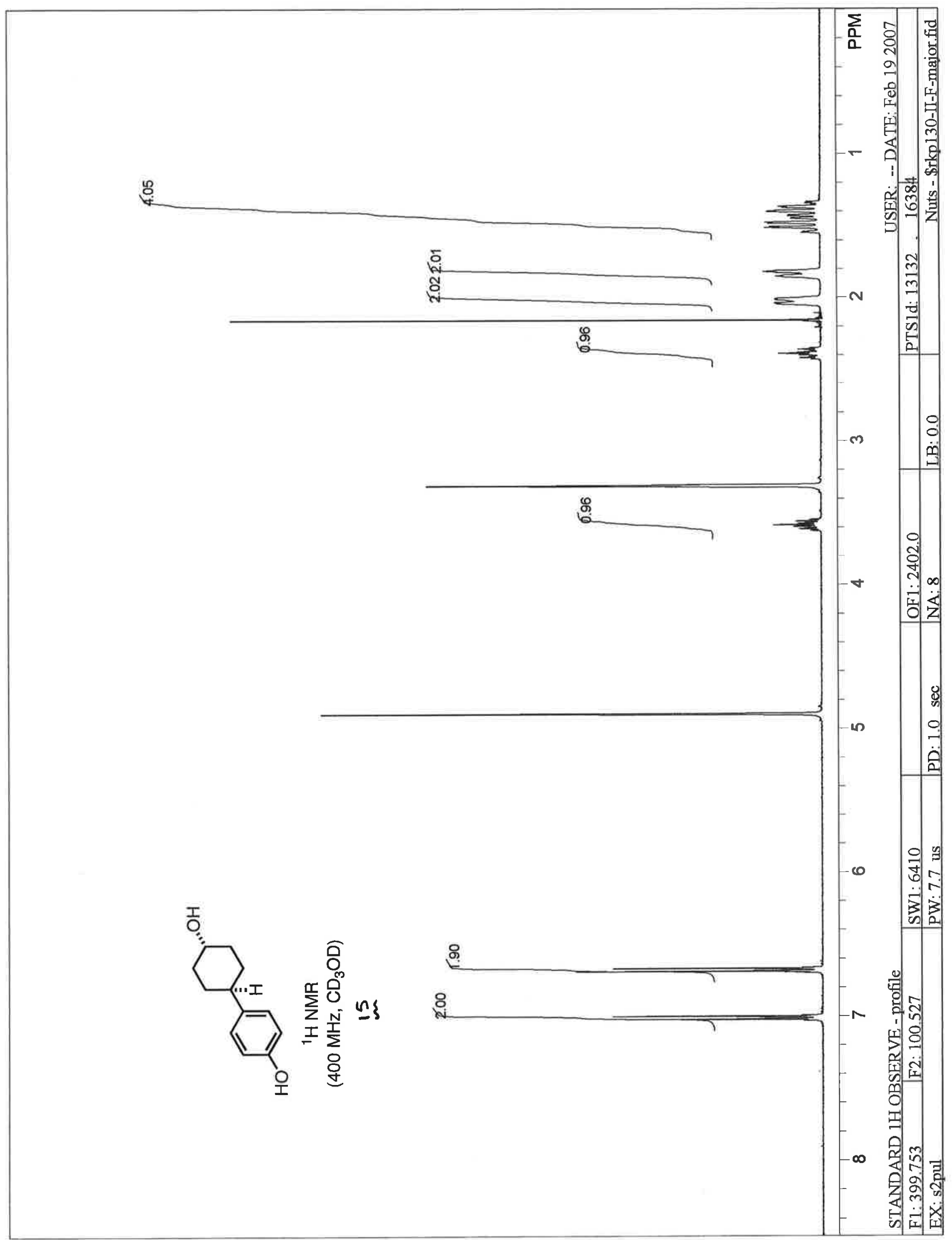




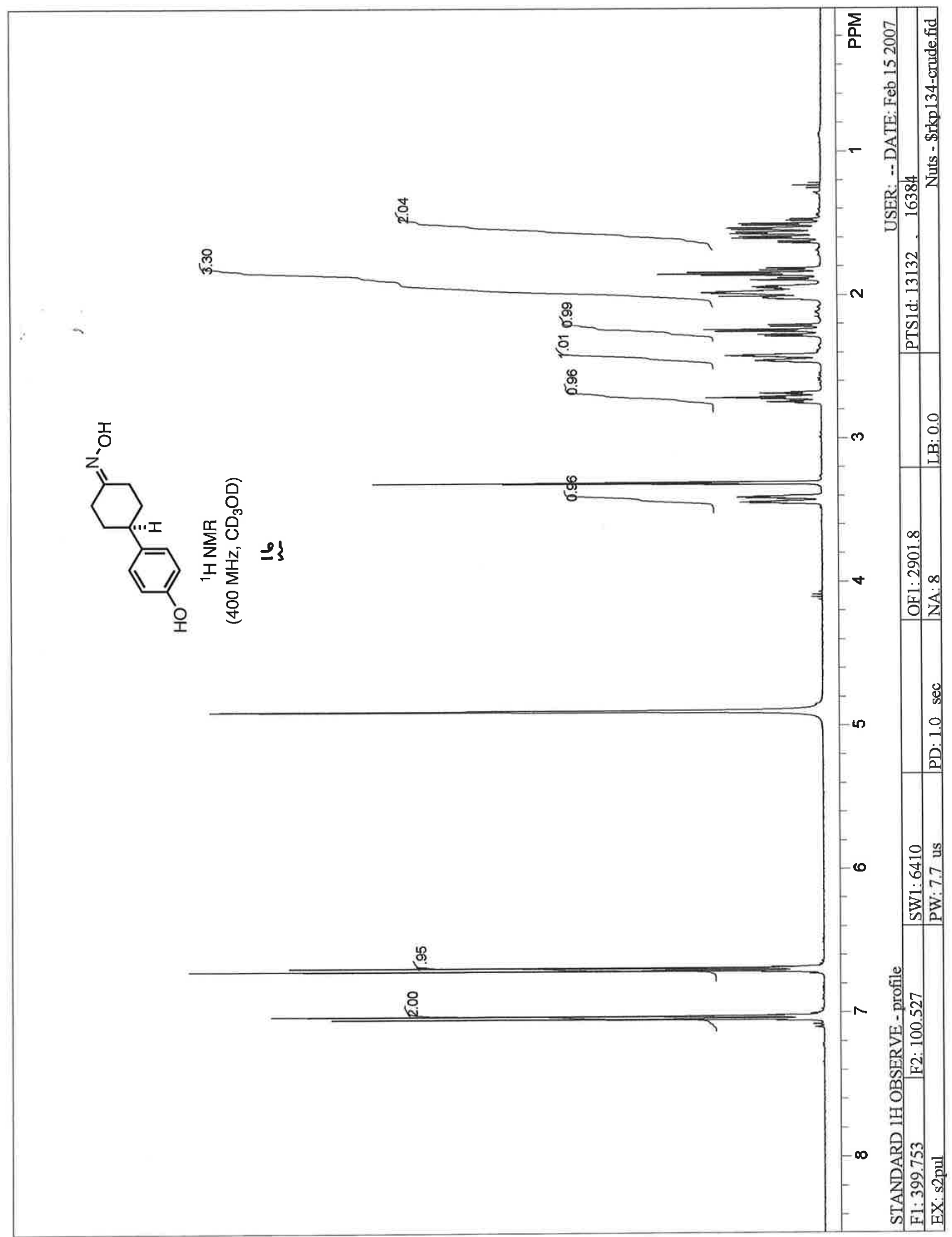




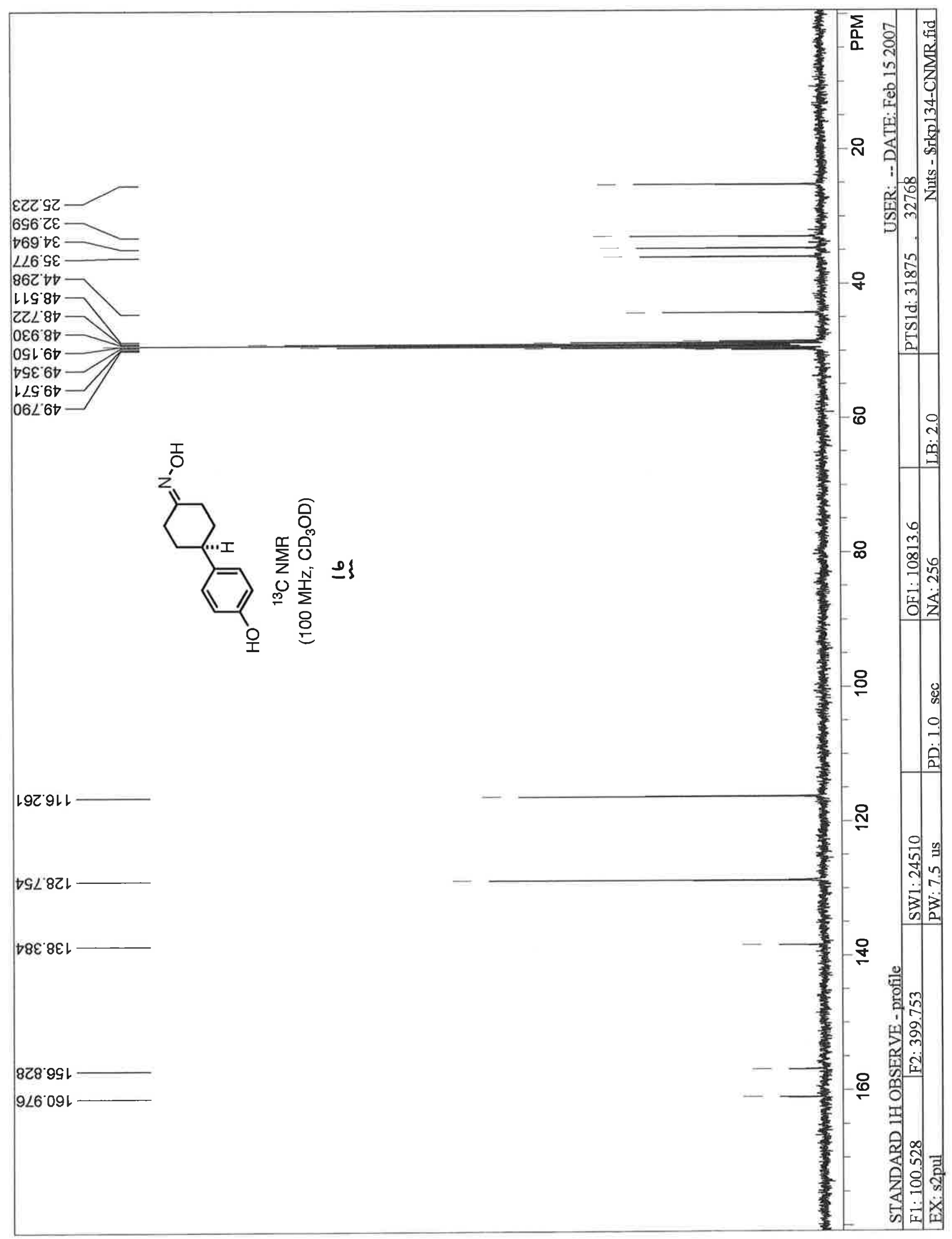




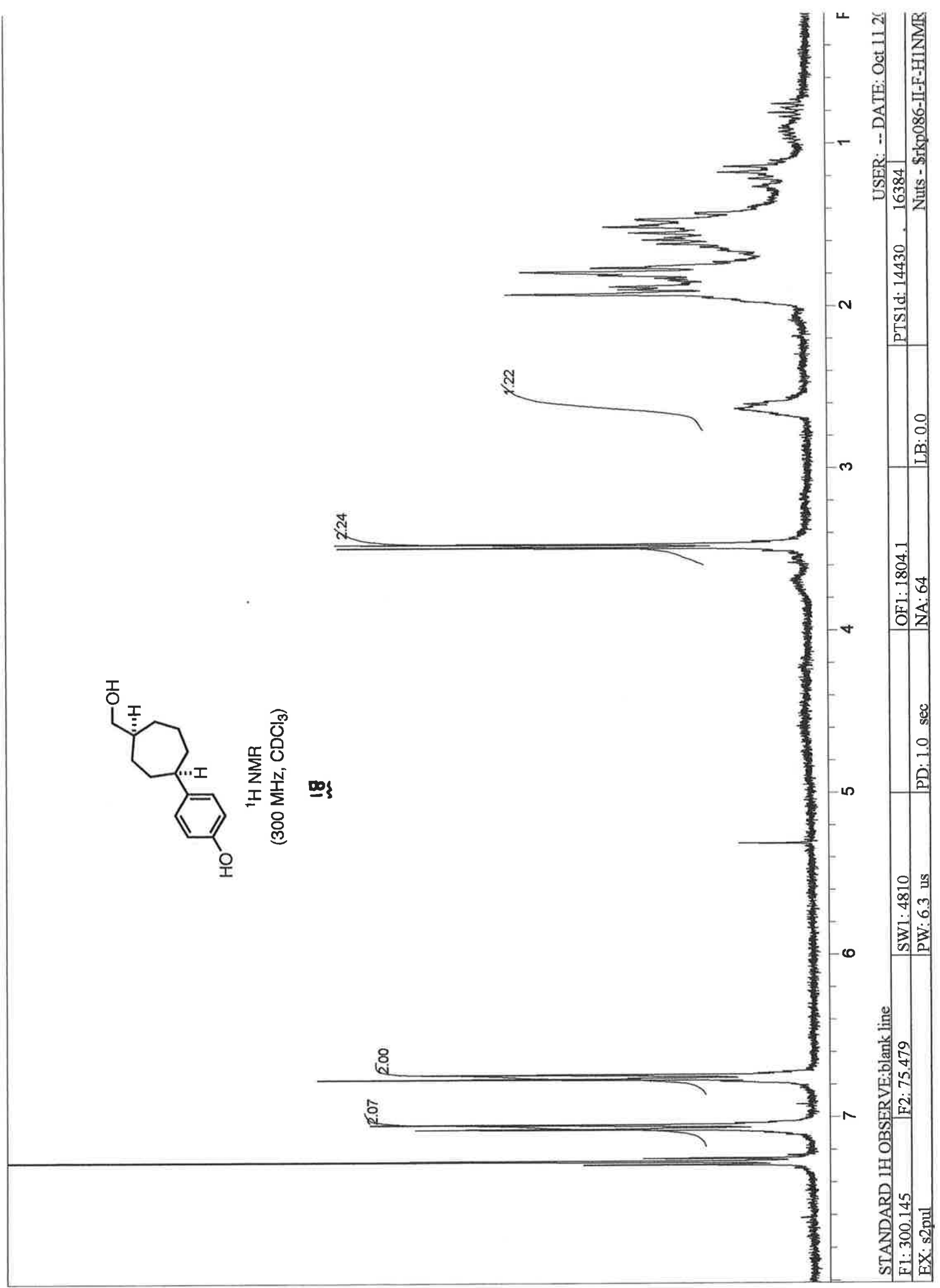


9ZS' $\angle Z$

8ZS' 82

$\angle L G^{\prime} L E$

ยเレยะ—_-

$9+8.8 \varepsilon$

เดE'เ

oso $9 \mathrm{t}$

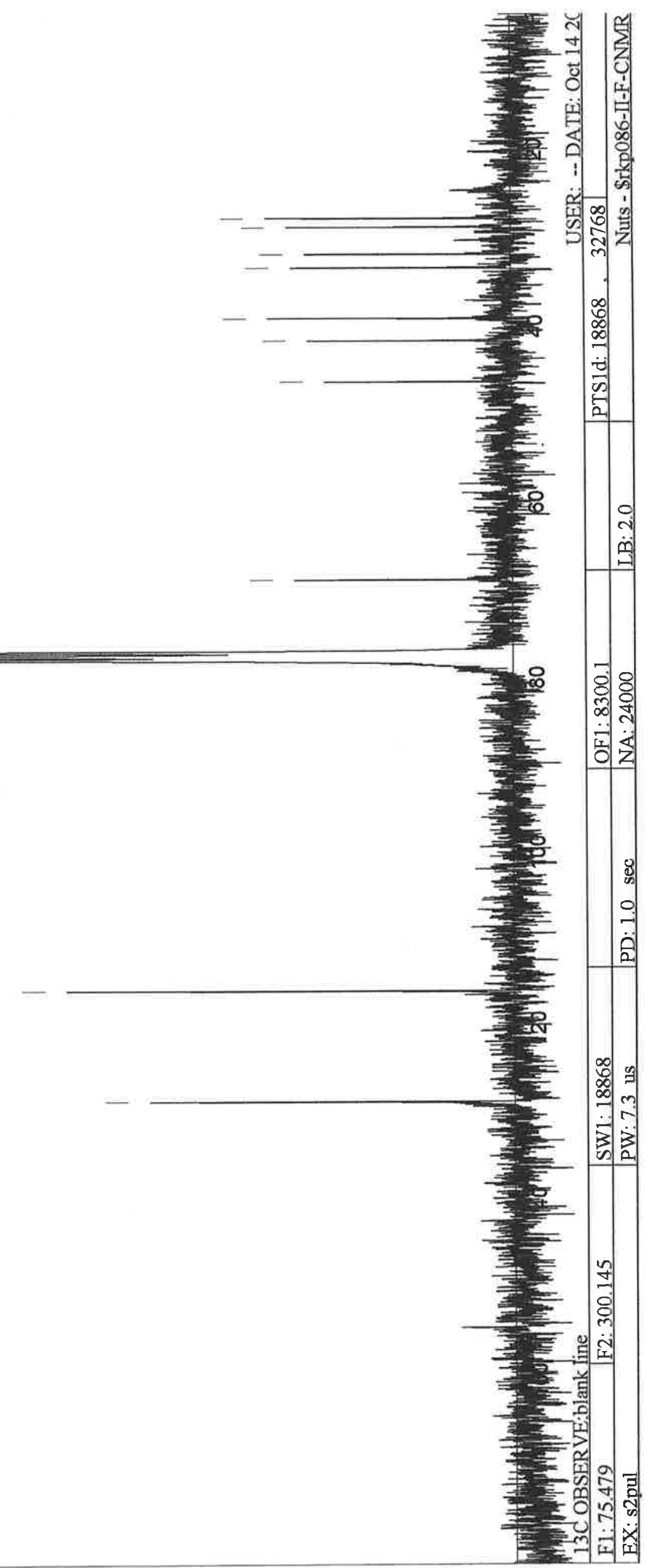

L89. 89

208.92

$0 \varepsilon Z \angle L$

$679^{\circ} \angle L$

LLZSIL

$888^{\circ} \mathrm{LZL}$

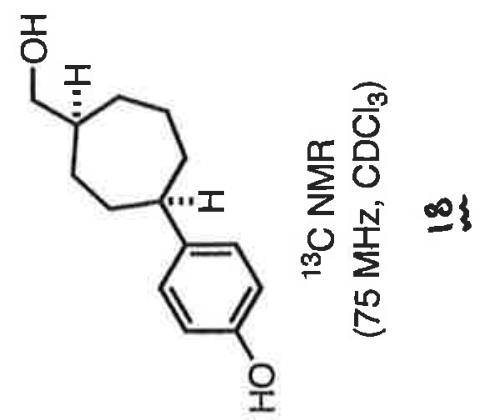




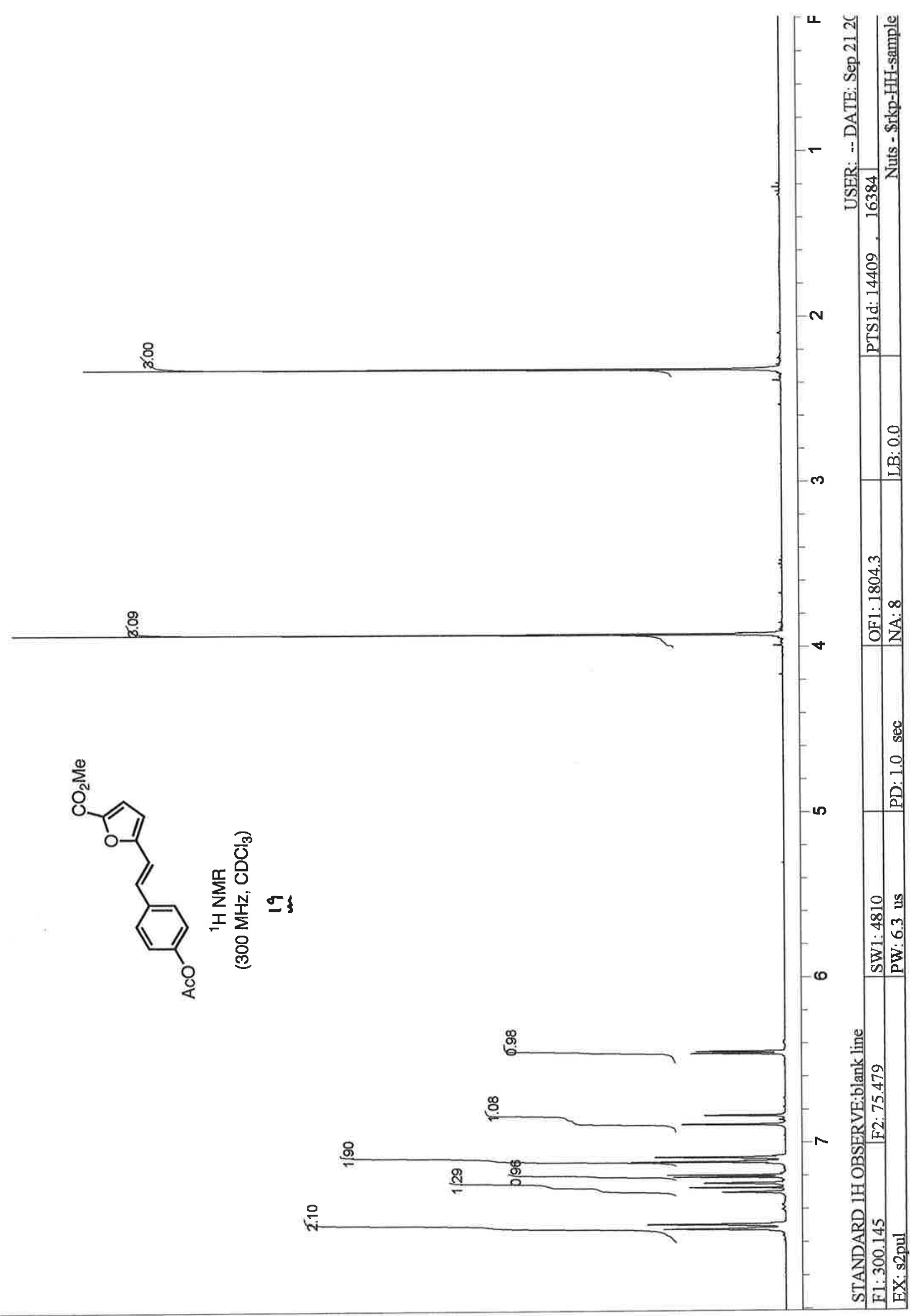




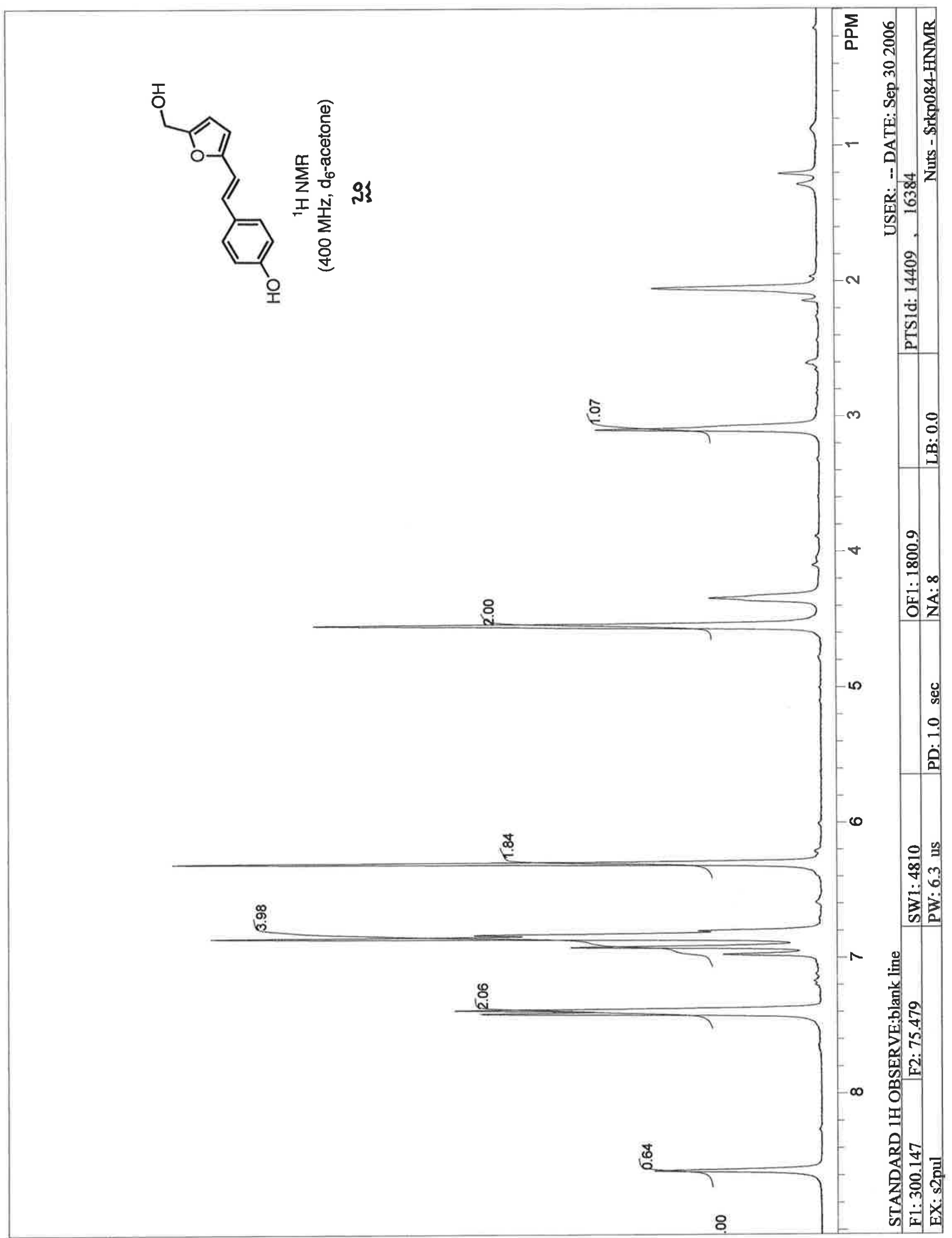




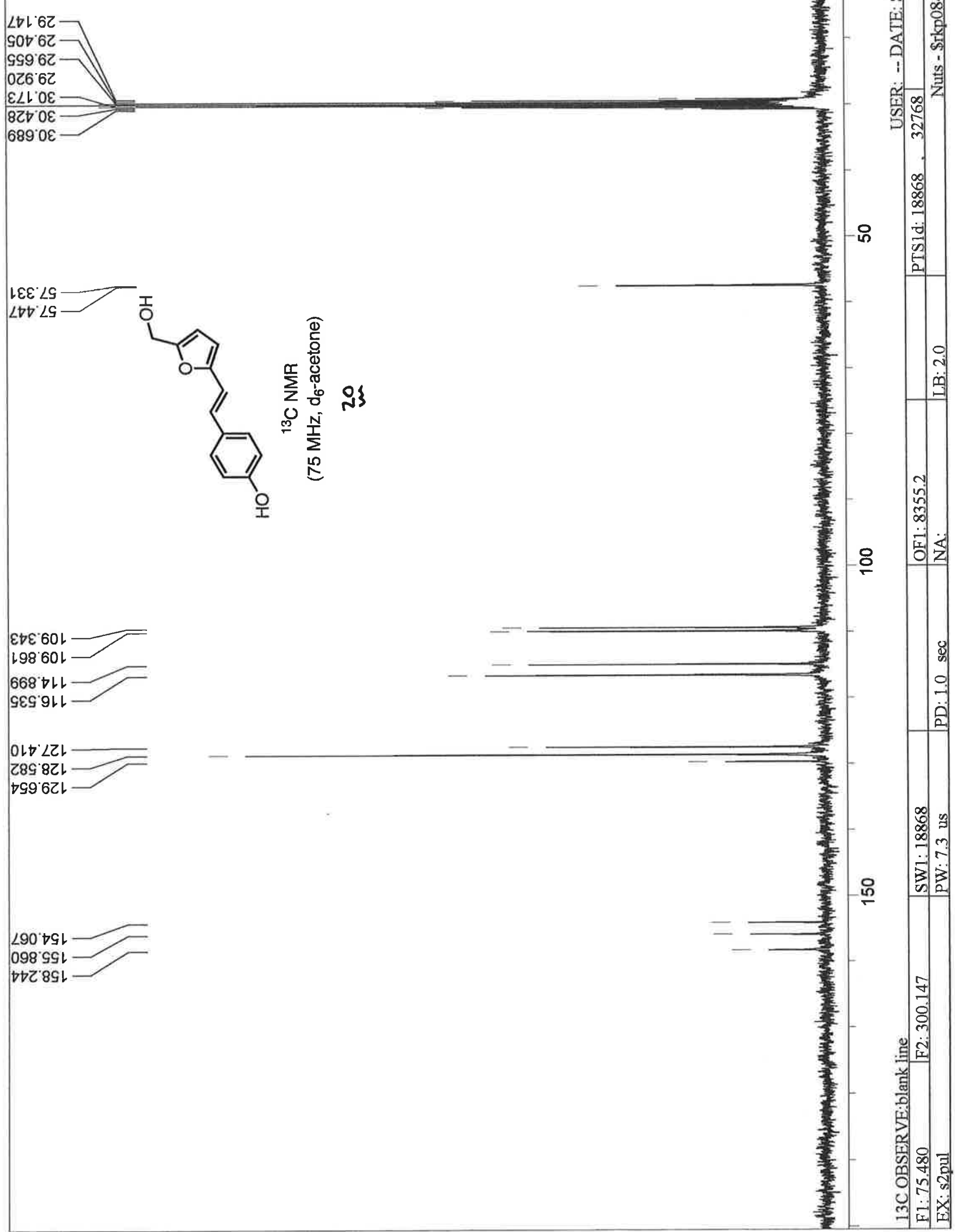

